\title{
The labour market by education and occupation to 1994. Prototype
}

Citation for published version (APA):

Researchcentrum voor Onderwijs en Arbeidsmarkt, ROA. (1991). The labour market by education and occupation to 1994. Prototype. Researchcentrum voor Onderwijs en Arbeidsmarkt, Faculteit der Economische Wetenschappen. ROA Reports No. 005E https://doi.org/10.26481/umarep.1991005E

Document status and date:

Published: 01/01/1991

DOI:

10.26481/umarep.1991005E

Document Version:

Publisher's PDF, also known as Version of record

\section{Please check the document version of this publication:}

- A submitted manuscript is the version of the article upon submission and before peer-review. There can be important differences between the submitted version and the official published version of record.

People interested in the research are advised to contact the author for the final version of the publication, or visit the DOI to the publisher's website.

- The final author version and the galley proof are versions of the publication after peer review.

- The final published version features the final layout of the paper including the volume, issue and page numbers.

Link to publication

\footnotetext{
General rights rights.

- You may freely distribute the URL identifying the publication in the public portal. please follow below link for the End User Agreement:

www.umlib.nl/taverne-license

Take down policy

If you believe that this document breaches copyright please contact us at:

repository@maastrichtuniversity.nl

providing details and we will investigate your claim.
}

Copyright and moral rights for the publications made accessible in the public portal are retained by the authors and/or other copyright owners and it is a condition of accessing publications that users recognise and abide by the legal requirements associated with these

- Users may download and print one copy of any publication from the public portal for the purpose of private study or research.

- You may not further distribute the material or use it for any profit-making activity or commercial gain

If the publication is distributed under the terms of Article $25 \mathrm{fa}$ of the Dutch Copyright Act, indicated by the "Taverne" license above, 
THE LABOUR MARKET BY EDUCATION AND OCCUPATION TO 1994

-Prototype-

ROA-R-1991/5E

RESEARCH CENTRE FOR EDUCATION AND THE LABOUR MARKET

Faculty of Economic Science

University of Limburg

Maastricht, August 1991 
CIP-GEGEVENS KONINKLIJKE BIBLIOTHEEK, DEN HAAG

Labour

The labour market by education and occupation to 1994: prototype / Research Centre for Education and the Labour Market. - Maastricht: Research Centre for Education and the Labour Market, Faculty of Economic Science, University of Limburg. -(Report/Research Centre for Education and Labour Market, ISSN 0922-8098; 1991/5E) Vert. van: De arbeidsmarkt naar opleiding en beroep tot 1994: prototype. - Maastricht: Researchcentrum voor Onderwijs en Arbeidsmarkt, Faculteit der Economische Wetenschappen, Rijksuniversiteit Limburg, 1991. (Rapport/Researchcentrum voor Onderwijs en Arbeidsmarkt, ISSN 0922-8098; 1991/5). - Met lit. opg.

ISBN 90-5321-074-1 geb.

Trefw.: arbeidsmarkt; Nederland; toekomst/Onderwijs en arbeidsmarkt; Nederland; toekomst. 


\section{CONTENTS}

1. INTRODUCTION

2. FLOWS IN THE LABOUR MARKET

2.1. Introduction 3

2.2. Expansion demand, replacement demand and outflow 6

3. THE MARKET POSITION OF TYPES OF EDUCATION AND OCCUPATIONAL CLASSES 17

$\begin{array}{ll}3.1 . \text { Introduction } & 17\end{array}$

3.2. The labour market prospects: demand and supply compared 17

3.3. The market position of occupational classes 19

3.4. The market position of types of education 24

4. DEVELOPMENTS IN THE QUALIFICATION STRUCTURE AND THE EMPLOYMENT STRUCTURE $\quad 30$

4.1. Introduction 30

4.2. Changes in the qualification structure $\quad 30$

4.3. Changes in the occupational structure $\quad 35$

4.4. Shifts in the educational structure $\quad 38$

5. SEX, EDUCATION AND THE LABOUR MARKET

5.1. Introduction $\quad 41$

5.2. Participation rate, part-time labour and unemployment $\quad 41$

5.3. Education and occupational segregation $\quad 45$

5.4. Labour market characteristics of women's occupations 48

5.5. Labour market characteristics of women's types of education 51

$\begin{array}{ll}\text { REFERENCES } & 55\end{array}$ 


\section{PREFACE}

The Research Centre for Education and the Labour Market (ROA) is developing the Information System for Education and Labour Market, on behalf of the Ministry of Education and Science. This system is intended to provide up-to-date information about the labour market in relation to education, and short and medium-term forecasts of the disequilibrium between the two subsystems. One important application of this information system is the Information System on Education and Employment, I-See!. This system is a project of the National Career Guidance Information Centre (LDC). I-See! contains a considerable amount of data, on CD-ROM, about more than 17,000 educational possibilities and around 1,500 occupations. This data has been combined, in I-See!, with the labour market information which ROA provides about occupations and educational possibilities. Thus an important information need in the field of study and occupational choice is satisfied.

However ROA's Information System for Education and the Labour Market has broader application possibilities. This programming year ROA has initiated some projects intended to extend the information system's application possibilities and relevance to policy ${ }^{1}$. One of these projects involves examining the possibility of regionalizing the information system, so that a contribution can be made to the needs of regional labour exchanges and trade and industry, and provincial and municipal authorities, for data at a regional level. Another project concerns the development of a report for policy-makers. This report, in which the most important data in the information system are further analyzed, would appear with up-dated forecasts every two years.

The present analysis is a prototype for this policy-orientated report. It is intended to support policy-making by government, labour exchanges, unions and employers, and organizations in the educational field. The report includes ROA's forecasts for the period 1989-1994. After evaluation by the main users, the report will receive a more definitive form at the end of 1991, using forecasts which will be completely up-dated then.

The Information System for Education and the Labour Market was constructed under the direction of Prof. Dr. J.A.M. Heijke and Dr. A. de Grip. The data from this information system has been the basis of the present report. Within ROA, Dr. R.K.W. van der Velden was responsible for the analyses done specifically for this report, and for the final wording.

1. See ROA (1990), Het informatiesysteem onderwijs-arbeidsmarkt, onderzoekprogramma 1990/1991, Maastricht (ROA-R-1990/4). 
-ii-

Contributions were made by Drs. Th.B.J. Beekman, Drs. R.J.P. Dekker, Dr. A. De Grip and Drs.

$P$. van de Loo, while P. Ghijsen assisted in the data processing.

Maastricht, August 1991.

Prof. Dr. J.A.M. Heijke

Director. 


\section{INTRODUCTION}

This report is based on the data that is or will soon become available from the Information System for Education and the Labour Market, developed by ROA under contract from the Ministry of Education and Science. The report is intended to indicate the main trends in the labour market, accentuating the quantitative match of education and occupation and the changes which can be expected in this balance. The report is meant in the first place for policymakers concerned with this issue: government, labour exchanges, education authorities and unions and employers' organisations.

The report gives a description of the most important developments on the labour market and deals with a number of relevant themes. In contrast to other Dutch labour market reports, ${ }^{2}$ it concentrates on forecasts of the relationship between education and the labour market, and supplies information at a low level of aggregation.

The Information System distinguishes 21 sectors, 77 occupational classes and 54 types of education. The economic sectors are based on the classification used by the Central Planning Bureau (CPB) in the Central Economic Plan. The occupational classes follow the 2-digit level of the occupational classification used by the CBS (Central Bureau of Statistics) ${ }^{3}$. The types of education were divided on the basis of the Standard Educational Classification (3 digit) into 54 types of education relevant to the labour market.

No occupational or educational forecasts from third parties were included in this report because, at the low aggregation level used here, this would not be possible for the full width of the labour market. However, the working group "comparison and coordination of forecasts '89" of the interdepartmental Commission of Education and Labour Market Forecasting (OAP) has compared forecasts for the period 1985-1992 from the CPB, the Ministry of Education and Science, ROA, and others, admittedly at a much higher level of aggregation. They concluded

2. See Rapportage Arbeidsmarkt (Reporting on the Labour Market) by the Ministry of Social Affairs and Employment, the Trendrapport (Trend Report) by the Organisation of Labour Market Research (OSA), and the Central Planning Bureau's Toekomstverkenningen (Future Exploration).

3. As of the end of this year, a new occupational classification better suited to the analysis of matching problems will be used. This new classification is based on the training characteristics of those working in a particular occupational group (See Dekker, De Grip and Van de Loo, 1990). 
that the most important trend forecasts agreed with one another, and differences, if any, could be traced to the methodology used [Commission OAP, 1989].

The forecasts of others, as well as the internal evaluation ${ }^{4}$, can of course give reason for adjusting our own forecasting models. Thus, as a result of the work of the CPB [Kuhry and Van Opstal, 1987] the possibility of modelling changes in employment by occupation and education using a multinominal logit-model was examined [Peeters, 1990]. In addition, achieving compatibility with existing CPB forecasts of changes in employment by sectors and with the 'SKILL' forecasts of the number of school leavers from fulltime education ${ }^{5}$ is given a high priority in ROA's working guidelines.

The structure of the rest of the report is as follows. Section 2 gives a general impression of the main flows in the labour market. In section 3 the future demand and supply on the labour market are compared and the market position of occupational classes and types of education is gone into. Section 4 analyses structural shifts between 1979 and 1994, by sector and occupation as well as by types of education. Finally, section 5 considers the position of women in the labour market. The appendices contain detailed statistical information on the occupational classes and types of education that are distinguished in the report.

4. The set up of the information system can be traced in the various reports of ROA's work. Recently an initial evaluation report appeared, which examines the methods used in the different parts of the information system and makes a first evaluation of the forecasting results.

5. Responsibility for the SKILL forecasts has recently been transferred to the Ministry of Education and Science. 


\section{FLOWS IN THE LABOUR MARKET}

\subsection{Introduction}

Labour market forecasts can be divided into those relating to a given moment in the future and those relating to a future period. The latter approach, called the 'flow figures' approach, makes a more discerning description of the various underlying demand and supply factors possible. This is the approach chosen for the ROA information system. On the demand side, a distinction is made between expansion demand, which is due to changes in the level of employment for a certain occupation or type of education, and replacement demand, which is due to permanent or temporary retirement, mobility within the labour market, and so on. Matching this on the supply side of the labour market is the expected flow of school leavers ${ }^{6}$ onto the labour market and the reservoir of the long and short-term unemployed (see diagram 2.1).

The forecasts relate to the period 1989-1994. The employment forecasts of the Central Planning Bureau (CPB), for 21 economic sectors, were the starting point. These forecasts are expressed in terms of labour volume. On the basis of an estimate by the CPB of the expected increase in part-time work, these forecasts can be expressed in terms of numbers of working persons. The employment level for each economic sector that is thus obtained is then converted into the expected changes in employment for 77 occupational classes. This calculation is based on ROA's occupational model, with which the occupational structure of economic sectors can be forecast. Changes in the occupational structure are explained by means of technological development, trade cycle factors, and structural or long-term trend effects (see also Dekker, De Grip and Heijke, 1990). In this way the expected expansion demand (the change in employment levels) for each occupational class can be determined.

The replacement demand for each occupational class is determined by means of a cohort analysis of the outflows, by sex and age class, for every occupational class. The outflows for each age group over the analysis period are then corrected for cyclical effects on staff turnover during this period (the flow of working people to unemployment). On top of that, a correction is made for expected changes in the total participation rate for each sex and age group (see Willems and De Grip, 1990).

6. The term 'school leavers' is used throughout to include graduates from tertiary education and technical institutes. 
Figure 2.1. Supply and demand on the labour market

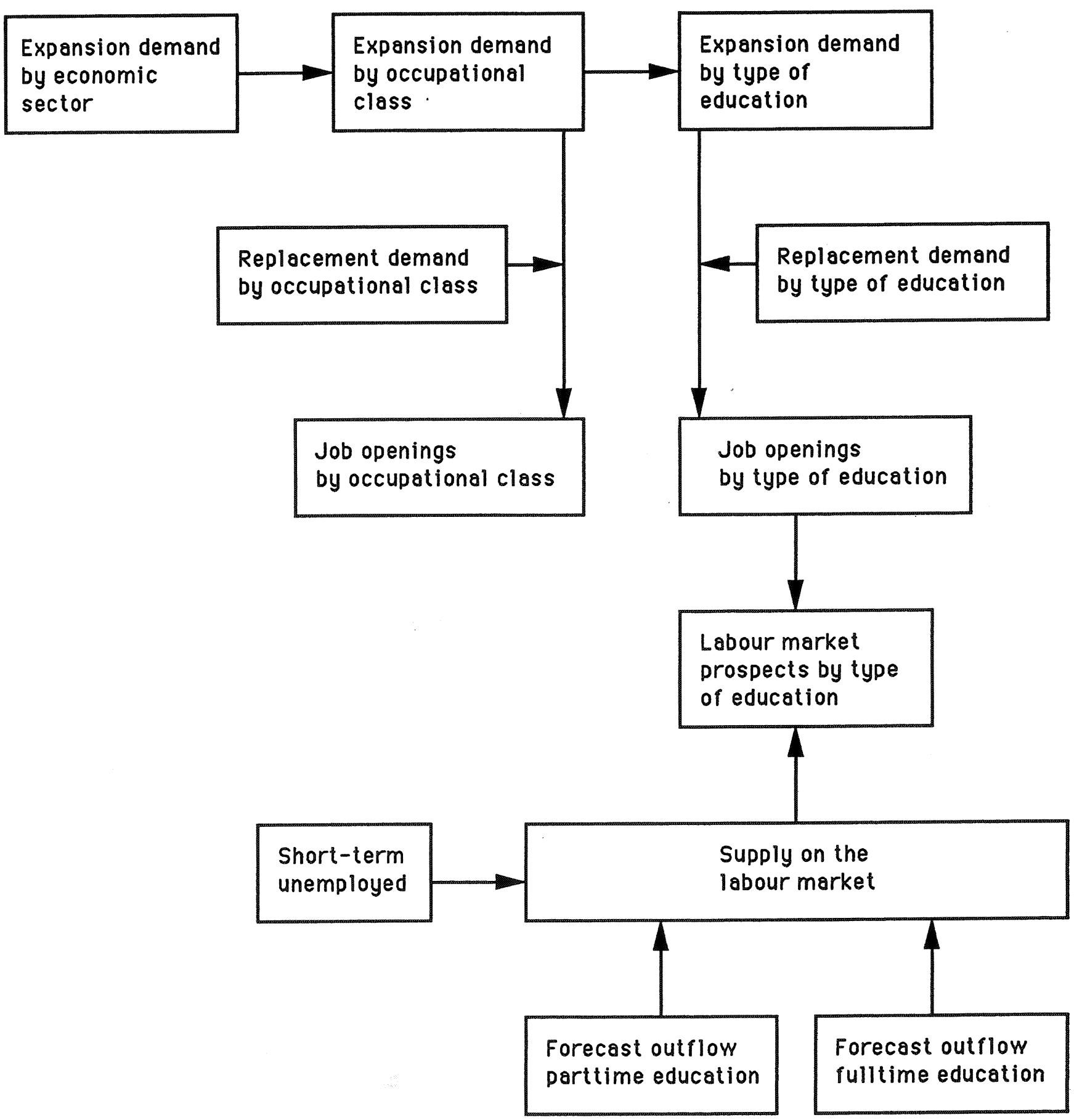


The expansion demand and the replacement demand together give the number of job openings per occupational class expected for the forecasting period.

The expected expansion demand per type of education is determined with the aid of the ROA model for types of education (see also Beekman, Dekker, De Grip and Heijke, 1989). This model analyses changes in the educational structure of occupational classes at economic sector level. Changes are explained on the basis of demand factors (technological development) and supply factors (substitution or displacement). Technological developments can explain an elevation (upgrading) or lowering (downgrading) of the skill level required to practice a certain occupation. The skills actually demanded on the labour market is also influenced by the relative scarcity of the different educational categories. By adjusting the relative reward or otherwise, an increasing supply of a certain educational category will, through this substitution mechanism, also lead to an increasing demand for this type of education.

The forecast of the expansion demand for each type of education is complemented by a forecast of replacement demand. The procedure is similar, but occupational mobility does not influence the replacement demand for a given type of education. In general, the replacement demand by types of education is therefore lower than the replacement demand by occupational classes. (see Willems and De Grip, 1990).

The job openings for each type of education (the sum of the expansion demand and the replacement demand) are then matched with the forecast flow of school leavers onto the labour market. This supply-side forecast is set up with the aid of the forecasts of the Ministry of Education and Science and various other data on the expected flow from part-time education (see also De Grip, Dekker and Heijke, 1989). In the final comparison of demand and supply for each type of education, the calculated flows are converted back into static figures, in which the population already working and the number of short-term unemployed at the beginning of the forecasting period are also taken into account. On the basis of this comparison, statements are made about the expected labour market prospects for each type of education.

In this section, the expansion demand and the replacement demand for occupational classes and for types of education will be discussed. Furthermore, the data on the expected flow of school leavers onto the labour market will be presented. The comparison of the two sets of data will follow in the next section. 


\subsection{Expansion demand, replacement demand and outflow}

Figure 2.2 shows changes in total employment in the Netherlands for the period of 1979 1994. The data here refer to the figures of the CPB, as revised by ROA.

Figure 2.2. General development in employment

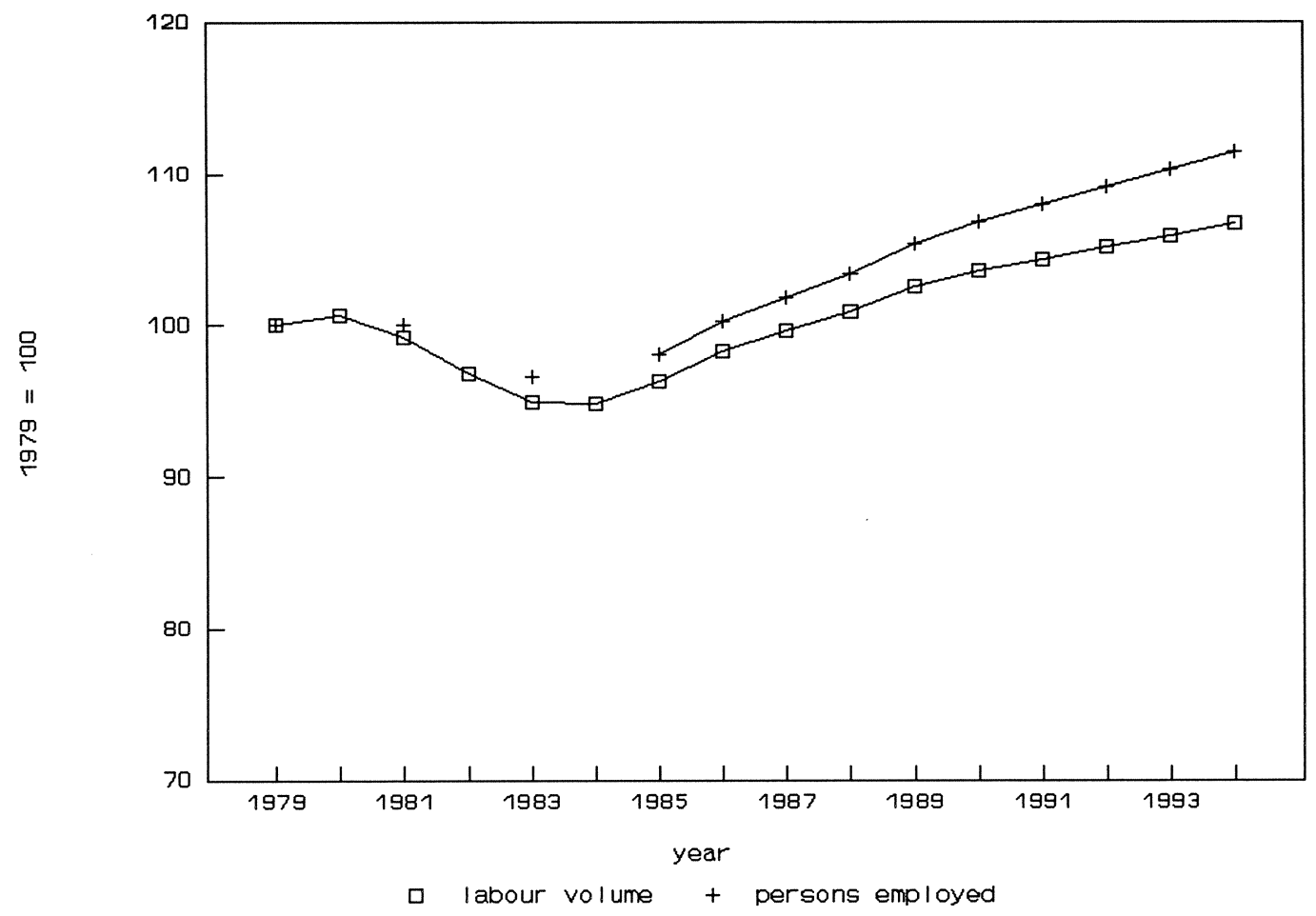

Source: $\mathrm{CPB} / \mathrm{ROA}$

In 1979 a total of over 5.2 million persons were working. After a decline in the early eighties, the total employment rises again from 1984 by an average of $1.8 \%$ per year. A further increase in the number working is forecast for the period 1989-1994. In all, an increase of 315,000 persons is expected. However, the growth rate will fall to $1.1 \%$ per year.

Relatively less favourable changes are expected in the labour volume: the decline in the early eighties has been stronger than was the case for the number of working persons, and the growth from the mid eighties has been less strong. The difference between the two developments is of course related to the increasing numbers of those working part-time. 
Table 2.1 shows how the labour volume has developed in the different sectors. The figures are based on CPB data. The table shows the average yearly growth rates in three periods, 19791985, 1985-1989 and 1989-1994, roughly corresponding with three trade cycle phases: a period of strong economic decline (until 1984), a period of strong economic growth (until 1989) and the forecasting period, for which moderate growth is forecast.

Table 2.1. Change in labour volume by sector 1979-1994 (average yearly growth rates)

\begin{tabular}{|c|c|c|c|c|}
\hline & & $\begin{array}{c}1979 / 85 \\
\%\end{array}$ & $\begin{array}{c}1985 / 89 \\
\%\end{array}$ & $\begin{array}{c}1989 / 94 \\
\%\end{array}$ \\
\hline 1 & Agriculture, fishing, forestry & -0.5 & -0.5 & -0.5 \\
\hline 2 & Manufacture of foodstuffs, beverages, tobacco products & -1.5 & -0.2 & -1.0 \\
\hline 3 & Manufacture of textiles, waering apparel, leather and & & & \\
\hline & footwear & -5.6 & 0.5 & -0.9 \\
\hline 4 & Manufacture of wood and building materials & -4.0 & 3.0 & 0.0 \\
\hline 5 & Manufacture of paper and printing and publishing industries & -1.2 & 2.4 & 0.0 \\
\hline 6 & Chemical industry and manufacture of rubber and plastic & & & \\
\hline & products & 0.0 & 2.3 & 1.6 \\
\hline 7 & Basic metal industries & -0.5 & 0.0 & 0.2 \\
\hline 8 & $\begin{array}{l}\text { Manufacture of metal products, mechanical and instrument } \\
\text { engineering }\end{array}$ & -1.8 & 1.5 & 0.5 \\
\hline 9 & Electrical engineering & -1.5 & 0.0 & 0.2 \\
\hline 10 & Manufacture of transport equipment & -2.6 & -0.8 & 0.2 \\
\hline 11 & Mining and quarrying & 1.0 & 0.5 & 0.1 \\
\hline 12 & Electricity, gas and water & 1.0 & 0.5 & 0.1 \\
\hline 13 & Construction & -4.5 & 2.6 & -0.2 \\
\hline 14 & Trade & -1.0 & 2.5 & 2.2 \\
\hline 15 & Sea and air transport & 0.4 & 2.2 & 1.3 \\
\hline 16 & Transport storage and communication & 0.4 & 2.2 & 1.3 \\
\hline 17 & Banking and insurances & 0.7 & 1.4 & 1.7 \\
\hline 18 & Other private services & 0.6 & 3.4 & 1.8 \\
\hline 19 & Medical and veterinary services & 1.7 & 1.5 & 0.7 \\
\hline 20 & Other public services & 1.4 & 1.5 & 0.9 \\
\hline 21 & Public administration and education & 0.8 & 0.4 & -0.1 \\
\hline \multicolumn{2}{|c|}{ Total } & -0.6 & 1.6 & 0.8 \\
\hline
\end{tabular}

Source: $\mathrm{CPB} / \mathrm{ROA}$

The recession in the early eighties had an especially unfavourable effect on the textile and clothing industry, the lumber and construction materials industry and the building industry. The non-commerçial sector (including government), and in particular medical and veterinary services and the 'miscellaneous' non-commercial services, had growing labour volume in this period. The picture in the second half of the eighties is different. Sectors that strongly profited from the economic growth were: miscellaneous tertiary services and house construction, the lumber and construction materials industry, trade, the building industry and the paper and printing industry. 
For the forecasting period the differences in the change in the labour volume between sectors are less striking. For the food and confectionary industry, the textile and clothing industry, and for agriculture and fisheries a slight decline in the labour volume is expected. Growth sectors are in trade, other tertiary services and construction, the banking and insurance industry, the chemical industry, the transport sector and the non-commercial sector (which includes government).

Table 2.2. Strongly growing occupational classes in the period 1989-1994

\section{Absolute}

\begin{tabular}{llrl}
\hline CBS & Occupational class & number & $\%$ \\
\hline & & \\
97 & Freight handlers, packers \& construction machine operators & 46600 & 25 \\
08 & Programmers, statisticians, and assistants etc. & 45400 & 57 \\
21 & Company directors and senior executives & 42300 & 10 \\
48 & Shop assistants etc. & 29700 & 36 \\
37 & Postal workers and mail clerks & 22000 & 11 \\
$02 / 03$ & Architects, engineers and related technicians & 21200 & 7 \\
$06 / 07$ & Medical, dental pharmaceutical and veterinary professions and & & \\
& assistants & 20200 & 12 \\
33 & Bookkeepers, cashiers, etc. & 12600 & 3 \\
43 & Working proprietors, retail & 10700 & 3 \\
39 & Miscellaneous administrative personnel & & \\
\end{tabular}

Relative

\begin{tabular}{llrl}
\hline CBS & Occupational class & number & $\%$ \\
& & & \\
08 & Programmers, statisticians, and assistants etc. & 57 \\
37 & Postal workers and mail clerks & 22000 & 35 \\
15 & Authors, journalists etc. & 7400 & 26 \\
97 & Freight handlers, packers and construction machine operators & 46600 & 25 \\
21 & Company directors and senior executives & 42300 & 20 \\
43 & Working proprietors, retail & 12300 & 12 \\
40 & Managers, wholesale & 4600 & 12 \\
42 & Working proprietors, wholesale & 3500 & 12 \\
41 & Managers, retail & 2100 & 12 \\
$02 / 03$ & Architects, engineers and related technicians & 21200 & 11 \\
& & & \\
\hline
\end{tabular}

Table 2.2 shows which occupational classes profit most from the growth in employment in the period 1989-1994. The top part of the table indicates which occupational classes will grow the most in absolute terms. The bottom part indicates which occupational classes will have the greatest relative growth. The increase in employment is expressed as a percentage of the number of working persons in that particular occupational class in 1989. 
Occupational classes with a very strong absolute growth are the freight handlers, packers and construction machine operators, the programmers, statisticians and assistants, and the company directors and senior executives. The growth in these three occupational classes la total of 135,000 persons) accounts for over $40 \%$ of the total growth in employment in this period. Other strongly growing occupational classes are shop assistants, postal workers and mail clerks, architects, engineers and related technicians, and medical, dental, pharmaceutical and veterinary professions and their assistants. For the latter occupational class, however, the growth is, in relation to the size of the occupation, not so strong. The same applies to bookkeepers, cashiers and miscellaneous administrative personnel. There are only six occupational classes that could be called 'occupational winners' (De Grip, 1987) in both an absolute and a relative sense. Smaller occupational classes with good relative growth are the authors and journalists and working proprietors in the retail and wholesale trades.

Table 2.3. Strongly declining occupational classes in the period 1989-1994

\begin{tabular}{llrl}
\hline CBS & Occupational class & number & $\%$ \\
\hline & & & \\
45 & Departmental managers, purchasing and sales & -18 \\
83 & Blacksmiths, toolmakers, and miscellaneous metalworkers & -3900 & -14 \\
61 & Farmers & -3500 & -3 \\
38 & Radio, telephone and telegraph operators & -3300 & -23 \\
80 & Shoemakers and leather goods workers & -3290 & -5 \\
95 & Building trades and construction workers & -3200 & -2 \\
62 & Agricultural workers & -2300 & -2 \\
92 & Printers and related functions & -2100 & -5 \\
98 & Drivers, sailors, engine drivers & -1400 & -1 \\
85 & Electrical and electronics workers, etc. & -1100 & -1 \\
\end{tabular}

Table 2.3. shows which occupational classes will decline rapidly, according to the forecast. Comparing the figures to those of table 2.2, the first thing one notices is that the figures for growth are far more spectacular than the figures for decline. A relatively strongly declining occupational class is that of departmental managers in purchasing and sales, which is remarkable because the other management occupations belong to the growth group. Other declining groups are connected mainly to traditional occupations in industry and to agriculture. The table also indicates the relative rates of decline, strongest among radio, telephone and telegraph operators, departmental managers in purchasing and sales, and blacksmiths, toolmakers, and miscellaneous metal workers. For the other occupational classes mentioned, the decline amounts to only a few percent. $^{7}$

7. There are other occupational classes with a strong relative decline, but these are very small occupational classes, so that these forecasts have little significance. 
Table 2.4. Occupational classes with a high replacement demand in the period 1989-1994

Absolute

\begin{tabular}{|c|c|c|c|}
\hline CBS & Occupational class & number & $\%$ \\
\hline 48 & Shop assistants etc. & 55200 & 19 \\
\hline 39 & Miscellaneous administrative personnel & 48100 & 12 \\
\hline 33 & Bookkeepers, cashiers, etc. & 38300 & 13 \\
\hline 32 & Secretaries, typists, etc. & 27300 & 18 \\
\hline 13 & Teachers & 25300 & 8 \\
\hline 54 & Miscellaneous domestic, geriatric care, and hotel workers & 25300 & 15 \\
\hline 62 & Agricultural workers & 24300 & 18 \\
\hline 83 & Blacksmiths, toolmakers, and miscellaneous metalworkers & 23500 & 14 \\
\hline 96 & Machine operators & 22500 & 12 \\
\hline 06/07 & $\begin{array}{l}\text { Medical, dental pharmaceutical and veterinary professions } \\
\text { and assistants }\end{array}$ & 22100 & 8 \\
\hline
\end{tabular}

\section{Relative}

\begin{tabular}{|c|c|c|c|}
\hline CBS & Occupational class & number & $\%$ \\
\hline 69 & Military professionals & 9300 & 22 \\
\hline 64 & Fishermen, hunters, etc. & 800 & 22 \\
\hline 60 & Farm managers and supervisors & 1600 & 21 \\
\hline 38 & Radio, telephone and telegraph operators & 2900 & 20 \\
\hline 72 & Furnace, casting, and galvanising workers, etc. & 2000 & 20 \\
\hline 14 & Ministers of religion, etc. & 1700 & 19 \\
\hline 48 & Shop assistants, etc. & 55200 & 19 \\
\hline 56 & Launderers, dry-cleaners and pressers & 2000 & 18 \\
\hline 32 & Secretaries, typists, etc. & 27300 & 18 \\
\hline 62 & Agricultural workers & 24300 & 18 \\
\hline
\end{tabular}

The growth in employment is not the only major factor in determining the number of job openings in a particular occupational class. Replacement demand as a result of, for instance, retirement is also very important (see table 2.4). Many of the traditional women's occupations, such as shop assistants, secretaries and typists, miscellaneous administrative personnel, radio, telephone and telegraph operators, domestic, geriatric care and hotel workers, and medical, dental, pharmaceutical and veterinary professions and their assistants, can be found among those occupations with a high replacement demand (see also section 5). As has been mentioned before, some of these occupational classes (shop assistants, medical, dental, pharmaceutical and veterinary professions and assistants and miscellaneous administrative personnel) also have a high absolute expansion demand. In an absolute sense there is also a high replacement demand for bookkeepers and cashiers, teachers, agricultural workers and some industrial occupations. A high relative replacement demand is found among agricultural 
workers and military professionals. The other occupational classes with a high relative replacement demand are rather small.

Table 2.5. Occupational classes with a low replacement demand in the period 1989-1994

\section{Absolute}

\begin{tabular}{|c|c|c|c|}
\hline CBS & Occupational class & number & $\%$ \\
\hline 78 & Tobacco and tobacco product workers & 100 & 4 \\
\hline 36 & Conductors, transport services & 200 & 7 \\
\hline 63 & Forestry workers & 250 & 6 \\
\hline 31 & Senior civil servants & 400 & 2 \\
\hline 20 & Senior Government appointees & 550 & 11 \\
\hline 91 & Process workers, paper and card products & 600 & 11 \\
\hline 82 & Cabinetmakers, woodworkers, stonemasons, etc. & 800 & 4 \\
\hline 64 & Fishermen, hunters, etc. & 800 & 22 \\
\hline 94 & Miscellaneous craftsmen and production workers & 850 & 6 \\
\hline 89 & Glass and ceramics workers etc. & 900 & 10 \\
\hline
\end{tabular}

\section{Relative}

\begin{tabular}{llrl}
\hline CBS & Occupational class & number & $\%$ \\
\hline & & & \\
08 & Programmers, statisticians, and assistants, etc. & 1600 & 2 \\
31 & Senior civil servants & 400 & 2 \\
15 & Authors, journalists, etc. & 1100 & 4 \\
78 & Tobacco and tobacco product workers & 100 & 4 \\
81 & Cabinetmakers, woodworkers, stonemasons etc. & 800 & 4 \\
99 & Miscellaneous labourers & 2200 & 5 \\
63 & Forestry workers & 250 & 6 \\
94 & Miscellaneous craftsmen and production workers & 850 & 6 \\
37 & Postal workers and mail clerks & 4000 & 7 \\
93 & Painters & 2400 & \\
\end{tabular}

These small occupational classes (fishermen and hunters, for instance) are naturally also found in the list of occupational classes with a low replacement demand in the absolute sense (table 2.5.). There are five occupational groups with low absolute and relative replacement demand: tobacco and tobacco product workers, forestry workers, senior civil servants, cabinetmakers, woodworkers and stonemasons and miscellaneous craftsmen and production workers. Groups with a high expansion demand, such as statisticians and programmers and their assistants, authors and journalists, and the postal workers and mail clerks, have a relatively low replacement demand. 
Table 2.6. Types of education with a high number of job openings in the period 1989-1994, broken down to replacement demand and expansion demand

\begin{tabular}{|c|c|c|c|c|}
\hline Type of education & number & $\%$ & $\begin{array}{r}\% \text { replacement } \\
\text { demand }\end{array}$ & $\begin{array}{r}\% \text { expansion } \\
\text { demand }\end{array}$ \\
\hline \multicolumn{5}{|l|}{ Intermediate Vocational Education, Commerce \& } \\
\hline Administration & 227800 & 31 & 15 & 85 \\
\hline \multicolumn{5}{|c|}{ Intermediate Vocational Education, Non-medical } \\
\hline Laboratory & 103700 & 18 & 44 & 56 \\
\hline Lower General Secondary Education & 67000 & 15 & 64 & 36 \\
\hline Lower Vocational Education, Technical & 57100 & 12 & 100 & 0 \\
\hline \multicolumn{5}{|l|}{ Intermediate Vocational Education, Community } \\
\hline Care & 41600 & 29 & 62 & 38 \\
\hline \multicolumn{5}{|l|}{ Lower Vocational Education, Community } \\
\hline Care, Hotel \& Catering & 41100 & 18 & 85 & 15 \\
\hline Primary Education & 39200 & 6 & 100 & 0 \\
\hline Higher General Secondary Education & 34500 & 15 & 45 & 55 \\
\hline \multicolumn{5}{|l|}{ Higher Vocational Education, Commerce \& } \\
\hline Administration & 34000 & 24 & 17 & 83 \\
\hline Higher Vocational Education, Teacher training & 25800 & 12 & 68 & 32 \\
\hline
\end{tabular}

Relative

Type of education

number

$\% \quad \%$ replacement $\%$ expansion

demand demand

Academic Education, Econometrics \& Business

\begin{tabular}{|c|c|c|c|c|}
\hline Administration Technology & 3100 & 74 & 5 & 95 \\
\hline \multicolumn{5}{|l|}{ Higher Vocational Education, Business } \\
\hline Administration Technology & 1500 & 42 & 12 & 88 \\
\hline \multicolumn{5}{|l|}{ Academic Education, Economics \& Business } \\
\hline Administration & 10300 & 35 & 17 & 83 \\
\hline \multicolumn{5}{|l|}{ Intermediate Vocational Education, Commerce \& } \\
\hline Administration & 227800 & 31 & 15 & 85 \\
\hline \multicolumn{5}{|l|}{ Intermediate Vocational Education, Community } \\
\hline Care & 41600 & 29 & 62 & 38 \\
\hline $\begin{array}{l}\text { Lower Vocational Education Transport \& Harbour } \\
\text { Higher Vocational Education, Commerce \& }\end{array}$ & 6200 & 27 & 32 & 68 \\
\hline Administration & 34000 & 24 & 17 & 83 \\
\hline \multicolumn{5}{|l|}{ Intermediate Vocational Education, Para-medical } \\
\hline services & 8700 & 24 & 60 & 40 \\
\hline $\begin{array}{l}\text { Intermediate Vocational Education, Nursing } \\
\text { Intermediate Vocational Education, }\end{array}$ & 20700 & 21 & 58 & 42 \\
\hline Medical Laboratory & 4500 & 21 & 52 & 48 \\
\hline
\end{tabular}


Table 2.7. Types of education with a low number of job openings in the period 1989-1994, broken down to replacement demand and expansion demand

Absolute

Type of education

number

$\% \quad \%$ replacement \% expansion demand demand

\begin{tabular}{|c|c|c|c|c|}
\hline Academic Education, Fine Arts & 150 & 9 & 55 & 45 \\
\hline Lower Vocational Education, Security & 300 & 3 & 100 & 0 \\
\hline \multicolumn{5}{|l|}{ Higher Vocational Education, Interpreter } \\
\hline \& Translator & 350 & 5 & 100 & 0 \\
\hline Academic Education, Pharmacy & 500 & 13 & 34 & 66 \\
\hline Academic Education, Agriculture & 650 & 11 & 53 & 47 \\
\hline Higher Vocational Education, Theology & 700 & 19 & 62 & 38 \\
\hline \multicolumn{5}{|l|}{ Higher Vocational Education, Hotel \& Catering } \\
\hline Industry & 750 & 19 & 43 & 57 \\
\hline \multicolumn{5}{|l|}{ Higher Vocational Education, Police, } \\
\hline Fire \& Defence Forces & 850 & 11 & 66 & 34 \\
\hline Academic Education, Theology & 1300 & 18 & 81 & 19 \\
\hline Higher Vocational Education, Agriculture & 1300 & 11 & 62 & 38 \\
\hline
\end{tabular}

\section{Relative}

Type of education

number

$\% \quad \%$ replacement

$\%$ expansion demand demand

Lower Vocational Education, Security

Higher Vocational Education, Interpreter \&

Translator

Primary Education

Higher Vocational Education, Fine Arts

Academic Education, Teacher training

Lower Vocational Education, Agriculture

Academic Education, Arts

Academic Education, Fine Arts

Intermediate Vocational Education,

Administrative, Legal \& Fiscal

Academic Education, Law \& Public Administration

$\begin{array}{rrrr}300 & 3 & 100 & 0 \\ 350 & 5 & 100 & 0 \\ 39200 & 6 & 100 & 0 \\ 1800 & 7 & 100 & 0 \\ 1500 & 7 & 60 & 40 \\ 8100 & 8 & 100 & 0 \\ 1700 & 8 & 65 & 35 \\ 150 & 9 & 55 & 45 \\ 3800 & 9 & 95 & 5 \\ 3300 & 10 & 56 & 44\end{array}$

The expansion demand and replacement demand for each occupational class has been converted by ROA to job openings per type of education. The top part of table 2.6 indicates which types of education have the highest demand in an absolute sense. The bottom part indicates which types of education have the highest demand in a relative sense (compared to 
the number of working persons with that particular educational background in 1989). ${ }^{8}$ In both relative and absolute terms there are a large number of job openings for Intermediate and Higher Vocational Education (hereafter I.V.E. and H.V.E.) in Commerce \& Administration, and for I.V.E. Community Care. For the first two this relates especially to a high expansion demand, for the latter especially to a high replacement demand. Strong demand in the absolute sense is found for technical education at a Lower Vocational Education level (hereafter L.V.E.) and the I.V.E. level, for all the varieties of general secondary education (i.e. Higher General Secondary Education and Lower General Secondary Education), for Primary Education and for teacher training at H.V.E. level. Especially for the lower types of education (L.V.E. Technical and primary education) the job openings consist mostly of replacement demand. A relatively strong demand which does relate principally to expansion demand is found for Academic Education (hereafter A.E.) in Econometrics and Business Administration Technology and in Economics and Business Administration, L.V.E. Transport and Harbour trades, and H.V.E. Business Administration Technology. A relatively high demand relating to both expansion and replacement is found for I.V.E. Para-medical Services, Nursing, and I.V.E. Medical Laboratory.

A limited number of job openings, in a relative as well as absolute sense, may be expected for A.E. Fine Arts, L.V.E. Security Services and H.V.E. Interpreters and Translators (table 2.7). Other types of education for which, relatively seen, few job openings may be expected, are: primary education (which offers, however, many openings in the absolute sense), H.V.E. Fine Arts, A.E. Teacher training, L.V.E. Agriculture, A.E. Arts (i.e., the humanities), I.V.E. Administration Legal and Fiscal, and A.E. Law and Public Administration. The other types of education for which a limited number of job openings in an absolute sense are expected are some of the smaller courses at H.V.E. and academic levels.

These developments all occur on the demand side of the labour market. An understanding of the position of educational categories on the labour market can only be obtained when these data are matched with changes on the supply side of the market. Table 2.8 reviews the types of education which will have a high output of school leavers in the forecasting period, in an absolute sense or as a percentage of the number of working persons with that educational background in 1989 .

8. For those not familiar with the Dutch education system a short explanation may be in order here. The system can be briefly described as divided into a general primary (basic) education and four further levels: lower (L), intermediate (I), Higher (H), and Academic. The lower, intermediate, and higher levels (secondary education) are not consecutive. They amount to an ability streaming system, with some switching possibilities. A great variety of different study 'directions' can be followed through one or more of these levels: the most important being general education and vocational education. 
The types of education with high absolute numbers of graduates are especially from Intermediate Vocational Education, general secondary education and also school leavers with only primary education. It should be remembered that school leavers are here divided according to the highest educational certificate they have obtained: the 'school leavers with primary education' are therefore drop-outs from secondary education, rather than students who never attended a secondary school. Types of education with a high relative output, on the other hand, are found especially in academic education and Higher Vocational Education. For a number of these types of education, the number of school leavers who will flow onto the labour market in the forecasting period 1989-1994 is higher or almost as high as the number of people with that educational background who were working in 1989. A very high relative outflow may be expected from the A.E. Fine Arts (an education that offers a very limited number of job openings), and from H.V.E. Business Administration Technology and A.E. Econometrics and Business Administration Technology (two types of education that showed a relatively high number of job openings), and from A.E. Arts.

Table 2.8. Types of education with high flows of school leavers onto the labour market in 1989-1994

Absolute

Type of education

number $\%$

Intermediate Vocational Education, Non-medical Laboratory

157500

Intermediate Vocational Education, Commerce \& Administration

132800

Higher General Secondary Education

Intermediate Vocational Education, Community Care

126400

54

Lower Vocational Education, Technical

$40300-49$

Higher Vocational Education, Teacher training

54200

11

Lower General Secondary Education

37900

18

Intermediate Vocational Education, Agriculture

37200

Higher Vocational Education, Technical

36700

35800

Relative

Higher Vocational Education, Business Administration

Technology

Academic Education, Econometrics \& Business Administration Technology(ir)

Academic Education, Arts 
The types of education with limited numbers of graduates were chiefly H.V.E. and academic courses (table 2.9). These are mainly rather specific, small-scale courses. In contrast, the types of education with low relative flows of school leavers are mainly varieties of lower and intermediate vocational education. For H.V.E. Interpreters \& Translators, A.E. Theology, and L.V.E. Commerce \& Administration and L.V.E.. Transport \& Harbour trades, the flow onto the labour market is limited in an absolute as well as in a relative sense. For H.V.E. Interpreters \& Translators this may compensate for the limited number of job openings, whereas for L.V.E. Transport and Harbour trades, considering the relatively high number of job openings, this may mean that the problems in personnel supply will become more acute. In the next section we will consider the matching of demand and supply further.

Table 2.9. Types of education with a low flow of school leavers to the labour market in 1989-1994

Absolute

Type of education

number

$\%$

Higher Vocational Education, Interpreter \& Translator

$650 \quad 9$

Higher Vocational Education, Theology

650

18

Academic Education, Theology

750

1000

10

Lower Vocational Education Transport \& Harbour

Higher Vocational Education, Police, Fire \& Defense Forces

1300

5

Academic Education, Pharmacy

1600

15

Higher Vocational Education, Hotel \& Catering Industry

2100

41

Higher Vocational Education, Medical Laboratory

2500

55

Academic Education, Teacher training

2800

16

Lower Vocational Education, Commerce \& Administration

2900

Relative

Type of education

number

$\%$

Lower Vocational Education, Commerce \& Administration

2900

1000

37200

Lower Vocational Education, Transp
Lower General Secondary Education

650

Higher Vocational Education, Interpreter \& Translator

20700

Lower Vocational Education, Community Care, Hotel \& Catering

10300

Academic Education, Theology

750

4300

6400

Intermediate Vocational Education, Administrative, Legal \& Fiscal

54200

Lower Vocational Education, Technical

3100 


\section{THE MARKET POSITION OF TYPES OF EDUCATION AND OCCUPATIONAL CLASSES}

\subsection{Introduction}

This section will examine the types of education for which shortages or absorption problems are expected. The likelihood of these problems is determined on the basis of the so-called 'indicator of the future labour market situation' (IFL) of an educational variety. ${ }^{9}$ For each type of education a comparison is made of the expected demand and supply of new entrants to the market. The supply consists on the one hand of the expected inflow in the period 1989-1994 and on the other hand of the number of unemployed with the same educational background that had been unemployed for less than one year in 1989 (see also diagram 2.1). The exclusion of those unemployed for more than one year is based on the supposition that they do not compete on the labour market with the school leavers of that type of education. Matching this supply, on the demand side of the labour market, is the sum of the expansion and replacement demand. Section 3.2 discusses the labour market indicators of specific types of education. An unfavourable labour market indicator does not automatically mean that school leavers will be confronted with unemployment, any more than a clear demand surplus will automatically lead to unfilled vacancies. The final consequences of a demand or supply surplus depend also on the market position of a particular type of education and occupational class, for instance on whether school leavers can switch to other sectors of the labour market or on the substitution possibilities between the types of education within an occupational class. Section 3.3 therefore looks at the market position of occupational classes, examining which occupational classes run a greater risk of supply problems. Section 3.4 focuses on the market position of the types of education, showing which types of education run a greater risk of absorption problems and which types are in a position to transfer possible problems to other supply categories.

\subsection{The labour market prospects: demand and supply compared}

The total number of job openings for a type of education, matched with the total supply of that education, gives an indication of the labour market prospects for this education. Table 3.1 shows which types of education are expected to have the best labour market prospects in the

9. See Wieling, 1990, for an explanation. 
period $1989-1994 .^{10}$

Table 3.1. Types of education with favourable labour market prospects in the period 1989-1994

$\begin{array}{lr}\text { Lower Vocational Education, Transport \& Harbour } & 0.84 \\ \text { Intermediate Vocational Education, Commerce \& Administration } & 0.91 \\ \text { Academic Education, Theology } & 0.95 \\ \text { Intermediate Vocational Education, Transport, Harbour \& Telecommunications } & 0.98 \\ \text { Lower Vocational Education, Community Care, Hotel \& Catering } & 0.99 \\ \text { Higher Vocational Education, Theology } & 1.00 \\ \text { Higher Vocational Education, Medical Laboratory } & 1.00 \\ \text { Higher Vocational Education, Commerce \& Administration } & 1.00 \\ \text { Intermediate Vocational Education, Police, Fire \& Defense Forces } & 1.01 \\ \text { Lower General Secondary Education } & 1.01 \\ \text { Intermediate Vocational Education, Medical Laboratory } & 1.02 \\ \text { Intermediate Vocational Education, Administrative, Legal \& Fiscal } & 1.02 \\ \text { Higher Vocational Education, Air, Sea and Land Transport } & 1.04\end{array}$

Types of education with good labour market prospects can be found especially in the following areas: Transport \& Harbour, Commerce \& Administration, Theology, and Medical Laboratory. If we look at the various levels of education, we see that I.V.E. and H.V.E. are especially well represented. L.V.E. Transport \& Harbour trades owes its favourable labour market prospects to a relatively high number of job openings combined with a relatively limited number of school leavers. The Commerce \& Administration courses at I.V.E. and H.V.E. level owe their favourable labour market prospects mainly to the high expansion demand in this sector. A relatively high number of job openings is also the main reason for the favourable position of I.V.E. Medical Laboratory. On the other hand, A.E. Theology, L.V.E. Community Care, Hotel \& Catering trades, I.V.E. Police, Fire \& Defense Forces, I.V.E. Administrative, Legal \& Fiscal, and H.V.E. Air, Sea \& Land Transport, along with Lower General Secondary Education have good prospects mainly because they have a relatively low outflow. It is remarkable that the technical educational varieties (excluding medical laboratory education) do not figure in this list. It is true that the expansion demand for these branches of study, particularly at H.V.E. and academic level, is relatively high. The replacement demand is relatively low however, while the flow of school leavers is average. The prospects of these types of education are therefore reasonably, rather than highly favourable.

10. The value 1.05 is a balance situation of demand and supply, since the frictional unemployment is set at $5 \%$. 
Table 3.2 shows the types of education with relatively unfavourable labour market prospects. The first striking feature is that supply surpluses threaten especially at the highest level (H.V.E. and A.E.) on the one hand and for unqualified people (with only primary education) on the other hand. Fine Arts and Agriculture are under particular threat. H.V.E. Business Administration Technology has a high place in the list, the only technically orientated education to appear there. Its bad labour market prospects are caused especially by the relatively high flow of graduates. This applies also for both of the agricultural courses, I.V.E. Social \& Cultural, and A.E. Law \& Public Administration. The A.E. Arts and Fine Arts owe their poor prospects to the limited number of job openings as well as to a very high relative outflow. This makes their position especially vulnerable. Finally, for those with Primary Education only, and for H.V.E. Fine Arts, the problem is mainly that the relative demand for these types of school leavers continues to be weak.

Table 3.2. Types of education with unfavourable labour market prospects in the period 1989-1994

Type of education indicator of future labour market

$\begin{array}{lr}\text { Academic Education, Fine Arts } & 2.62 \\ \text { Academic Education, Arts } & 1.80 \\ \text { Higher Vocational Education, Agriculture } & 1.64 \\ \text { Academic Education, Agriculture } & 1.64 \\ \text { Intermediate Vocational Education, Social \& Cultural } & 1.63 \\ \text { Academic Education Law \& Public Administration } & 1.62 \\ \text { Higher Vocational Education, Business Administration Technology } & 1.55 \\ \text { Primary Education } & 1.52 \\ \text { Higher Vocational Education, Fine Arts } & 1.49 \\ \text { Academic Education, Social Sciences } & 1.48 \\ \text { Higher Vocational Education, Nursing en Physiotherapy etc. } & 1.47 \\ \text { Higher General Secondary Education } & 1.43 \\ \text { Lower Vocational Education, Security } & 1.43\end{array}$

\subsection{The market position of occupational classes}

The last subsection showed that types of education with good labour market prospects are found especially in the following sectors: Transport \& Harbour, Commerce \& Administration, Theology, and Medical Laboratories. As for the level of education, I.V.E. and H.V.E. levels had good prospects. Occupational classes that depend largely on these types of education will also run the highest risk of problems in personnel supply. Whether these problems will indeed arise depends on a number of other factors. This subsection will discuss a number of factors that increase or diminish the likelihood of problems. It explicitly does not deal with the balancing of risks for suppliers of labour, but rather examines the risk factors on the demand side and in 
particular the degree to which an occupational class is dependent on school leavers, its cyclical sensitivity and the relative prestige of an occupational class. ${ }^{11}$ The relative replacement demand which we examined above (see the bottom section of table 2.4) can also indicate a risk factor, that is, in so far as it is related to high turnover in the occupational class. A high turnover can indicate relatively unattractive labour conditions.

Table 3.3. Occupational classes with a relatively high, or with a relatively low proportion of employees under thirty years old

High proportion

$\begin{array}{ll}\text { CBS Occupational class } & \text { proportion } \\ & <30 \text { years old }\end{array}$

$\begin{array}{lll}48 & \text { Shop assistants etc. } & 0.53 \\ 58 & \text { Fire, police and security officers } & 0.53 \\ 32 & \text { Secretaries, typists, etc. } & 0.52 \\ 06 / 07 & \text { Medical, dental, pharmaceutical and veterinary professions and } & \\ & \text { assistants } & 0.52 \\ 54 & \text { Miscellaneous domestic, geriatric care and hotel workers } & 0.50 \\ 77 & \text { Food and beverage processors, abattoir workers } & 0.50 \\ 78 & \text { Tobacco and tobacco product workers } & 0.49 \\ 34 & \text { Computer operators etc. } & 0.48 \\ 60 & \text { Farm managers and supervisors } & 0.48 \\ 33 & \text { Bookkeepers, cashiers, etc. } & 0.46\end{array}$

Low proportion

CBS Occupational class proportion

$<30$ years old

20 Senior Government appointees

50 Managers, hotel and catering industry 0.00

$\begin{array}{lll}31 & \text { Senior civil servants } & 0.02\end{array}$

21 Company directors and senior executives 0.05

40 Managers, wholesale 0.06

$14 \quad$ Ministers of religion etc. $\quad 0.09$

70 Production supervisors and general foremen 0.10

61 Farmers 0.12

$43 \quad$ Working proprietors, retail $\quad 0.12$

11 Accountants $\quad 0.12$

11. As of the coming year we intend, in addition to these risk factors, to look also at the degree to which workers with the various varieties of training offered for a given occupational class can substitute for one-another. 
The flow of school leavers onto the labour market will decrease in the early nineties by some $8 \%$ (see also section 5, figure 5.5). Because pupils increasingly continue their education for longer, this decrease is less than would be forecast on the basis of demographic developments. The decrease in the outflow is felt especially at the lower levels of vocational and general secondary education, due to the increased shift to continued education. At these levels the decrease in the outflow is about $30 \%$. Occupational classes that are strongly dependent on the flow of school leavers therefore run a greater risk of problems in personnel supply. Table 3.3 indicates the occupational classes in which relatively many people below thirty are working, and also those with relatively few. Among the occupational classes with a high proportion of younger people are relatively many of the traditional women's occupations (shop assistants, secretaries and typists, medical, dental, pharmaceutical and veterinary occupations, and miscellaneous domestic, geriatric care, and hotel workers). In the ten occupational classes concerned, half or more of the workers are younger than thirty. In two of these occupational classes there is also a high relative replacement demand: for shop assistants, and for secretaries and typists (see table 2.4). The occupational classes with a relatively low proportion of young workers are especially management functions and independent professions.

The labour security of an occupational class can be a risk factor as well. Occupational classes with a strongly fluctuating employment situation are in an unfavourable situation on the labour market. Occupational classes with a stable level of employment, on the other hand, are relatively attractive for those offering their labour. Table 3.4 shows the occupational classes that are concentrated in sectors which are highly sensitive to cyclical factors and also those which are concentrated in sectors in which employment trends have been relatively stable. ${ }^{12}$ Occupations which are highly sensitive to cyclical effects can be found in the textile and clothing, construction, and metal working industries. For the workers in base metals (furnace, casting and galvanizing workers) there is the extra problem of a relatively high replacement demand. Occupational classes with limited cyclical sensitivity are found in agriculture and fisheries, the food and drink industry, and in the public sector: education, army, government and public transportation.

12. The cyclical sensitivity of a sector, $\mathrm{Fl}_{\mathrm{b}}$ is calculated with the aid of a fluctuation index of the changes in employment levels in the sector, based on the absolute deviations from the employment trend between 1950 and 1988 (De Grip, Heijke and Dekker, 1989). The cyclical sensitivity of an occupational class is then determined as the weighted average of the cyclical sensitivity of the sectors in which the occupation is found. 
Table 3.4. Occupational classes with a relatively high or low cyclical sensitivity $\left(\mathrm{FI}_{\mathrm{b}}\right)$

High cyclical sensitivity

CBS Occupational class $\quad \mathrm{FI}_{\mathrm{b}}$

75 Spinners, weavers, knitters, dyers, etc. 3.9

80 Shoemakers and leather goods workers 3.3

$95 \quad$ Building trades and construction workers 3.3

79 Tailors, dressmakers etc. 3.1

93 Painters 3.0

$85 \quad$ Electrical and electronics workers $\quad 2.7$

87 Plumbers, welders, sheet metal workers etc. 2.7

99 Miscellaneous labourers $\quad 2.7$

83 Blacksmiths, toolmakers, and miscellaneous metalworkers 2.6

72 Furnace, casting, and galvanising workers etc. 2.6

Low cyclical sensitivity

CBS Occupational class $\mathrm{FI}_{\mathrm{b}}$

61 Farmers $\quad 1.0$

64 Fishermen, hunters, etc. $\quad 1.0$

69 Military professionals 1.0

13 Teachers 1.0

31 Senior civil servants 1.0

20 Senior Government appointees 1.1

78 Tobacco and tobacco product workers 1.1

36 Conductors, transport services 1.1

62 Agricultural workers 1.2

77 Food and beverage processors, abattoir workers $\quad 1.2$

The last risk factor discussed here is the relative prestige of an occupational class. Occupational classes are differentiated by the social prestige they enjoy (Sixma and Ultee, 1983). We can assume that occupations with a high prestige will also be attractive for potential employees, and this will affect the occupation's labour market position. Occupations with a low prestige, on the other hand, will probably be less attractive for those offering labour (unless there are other compensations such as higher wages). The problem here is that the prestige of an occupational class is strongly related to the occupational level: the higher the occupational level, the higher, in general, the prestige. Those offering labour, naturally, have within their reach only occupations of a certain level. For someone with L.V.E. level, the profession of accountant may have a high prestige, but it certainly is not obtainable and will therefore play no part in the weighing of possible alternative occupations. In choosing among occupations which are at an obtainable level, however, the relative prestige may well be a factor. Instead of using 
the occupational prestige as such, it is therefore more sensible to look at the relative prestige of an occupational class, that is, its prestige corrected for the function level, because it is this, and not the absolute prestige, which will influence the market position of an occupation.

Table 3.5. Occupational classes with a relatively low or with a relatively high prestige

Low prestige

\begin{tabular}{ccc} 
CBS Occupational class & relative & weighted \\
prestige & level of function \\
\hline
\end{tabular}

\begin{tabular}{llll}
99 & Miscellaneous labourers & -1.64 & 1.0 \\
56 & Launderers, dry-cleaners and pressers & -1.59 & 1.1 \\
55 & Caretakers, cleaners, etc. & -1.59 & 1.3 \\
77 & Food and beverage processors, abattoir workers & -1.54 & 2.4 \\
48 & Shop assistants etc. & -1.39 & 2.1 \\
90 & Process workers, rubber and plastic products & -1.38 & 1.3 \\
73 & Timber, pulp and paper workers & -1.38 & 1.8 \\
89 & Glass and ceramics workers etc. & -1.38 & 1.4 \\
91 & Process workers, paper and card products & -1.38 & 1.0 \\
80 & Shoemakers and leather goods workers & -1.32 & 1.9 \\
\hline
\end{tabular}

High prestige

\begin{tabular}{|c|c|c|c|}
\hline CBS & Occupational class & $\begin{array}{l}\text { relative } \\
\text { prestige }\end{array}$ & $\begin{array}{l}\text { weighted } \\
\text { level of function }\end{array}$ \\
\hline 20 & Senior Government appointees & 2.18 & 6.4 \\
\hline 12 & Legal professionals and assistants & 2.13 & 7.0 \\
\hline 21 & Company directors and senior executives & 2.08 & 6.0 \\
\hline 40 & Managers, wholesale & 1.72 & 6.0 \\
\hline 04 & Aircraft and ships'officers & 1.56 & 4.6 \\
\hline 09 & Economists & 1.41 & 6.0 \\
\hline 31 & Senior civil servants & 1.25 & 6.1 \\
\hline 08 & Programmers, statisticians, and assistants etc. & 1.18 & 6.0 \\
\hline 14 & Ministers of religion etc. & 1.15 & 5.7 \\
\hline 11 & Accountants & 1.15 & 6.2 \\
\hline
\end{tabular}

Table 3.5. shows the occupational classes with a high, and with a low relative prestige. ${ }^{13}$ The

13. The relative prestige is calculated as the residue from the regression of the standardized prestige of an occupational group against the standardized function level. The prestige of the occupational class is taken from Sixma and Ultee (1983). The function level of an occupational class is determined as the weighted average of the function levels of the underlying occupational groups (Huijgen, 1989). Since prestige scores at the level of occupational groups are virtually non-existent, we were forced to use the less detailed classification of occupational classes. 
average function level of the occupational class in question is also indicated. These level scores relate to the skill level required for a function and were taken from Huijgen (1989). The range is from 1 (unskilled labour) to 7 (academic work). The occupational classes with a low relative prestige all concern unskilled or semi-skilled work. In other words, despite the correction for function level, it is particularly occupations which require no, or only low, qualifications (in particular in industry) which have a low relative prestige. The opposite picture is found for functions with a high relative prestige: they are almost exclusively occupational classes at H.V.E. and academic level. Of the occupational classes with a relatively low prestige, there are two groups with a rather high replacement demand: the launderers, dry-cleaners and pressers and the shop assistants.

If one goes through the risk factors systematically again, there are a number of occupational classes that can be marked as having multiple risks for the demand side of the labour market. ${ }^{14}$ This concerns in the first place shop assistants: there is a high replacement demand, a high influx of younger people, and a low relative prestige. For secretaries and typists there is a relatively high replacement demand together with a high flow of younger people. For food and beverage processors and abattoir workers there is a high proportion of young people in the working population and low relative prestige. For labourers, industrial labourers, and shoemakers and leather goods workers there is a low relative prestige and high cyclical sensitivity. Finally, for the occupational class of furnace, casting and galvanizing workers there is high cyclical sensitivity as well as a relatively high replacement demand.

\subsection{The market position of types of education}

For types of education it is also true that a supply surplus does not automatically lead to absorption problems on the labour market, and that excess demand for a certain educational category does not automatically mean that school leavers from that category will find work. The occurrence of absorption problems is highly dependent on the position which an educational variety occupies on the market. In that respect a number of risk factors can be distinguished: current unemployment, the function level attained by graduates (does this fully utilise their qualifications), and the alternative possibilities on the labour market.

14. As of next year it is intended to give a composite indicator of the market position of the occupational groups. 
Table 3.6. Types of education with high or low unemployment (figures as of April 1990)

High unemployment

Type of education

$\%$

$\begin{array}{ll}\text { Academic Education, Fine Arts } & 32\end{array}$

$\begin{array}{ll}\text { Primary Education } & 28\end{array}$

$\begin{array}{lr}\text { Higher Vocational Education, Fine Arts } & 25\end{array}$

$\begin{array}{ll}\text { Academic Education, Arts } & 17\end{array}$

Higher General Secondary Education $\quad 17$

Lower Vocational Education, Commerce \& Administration $\quad 15$

Academic Education, Social Sciences $\quad 14$

$\begin{array}{ll}\text { Lower General Secondary Education, } & 14\end{array}$

$\begin{array}{ll}\text { Academic Education, Agriculture } & 13\end{array}$

Intermediate Vocational Education, Social \& Cultural $\quad 13$

$\begin{array}{ll}\text { Higher Vocational Education, Social \& Cultural } & 13\end{array}$

Low unemployment (less than 5\%)

$\begin{array}{ll}\text { Type of education } & \%\end{array}$

Intermediate Vocational Education, Police, Fire \& Defense Forces 0

Higher Vocational Education, Police, Fire \& Defense Forces $\quad 0$

Intermediate Vocational Education, Administrative, Legal \& Fiscal 1

Higher Vocational Education, Commerce \& Administration $\quad 1$

Intermediate Vocational Education, Commerce \& Administration 2

Intermediate Vocational Education, Non-medical Laboratory 2

Intermediate Vocational Education, Transport, Harbour \&

$\begin{array}{ll}\text { Telecommunications } & 2 \\ \text { Academic Education, Pharmacy } & 3\end{array}$

Higher Vocational Education, Engineering 3

Academic Education, Econometrics \& Business Administration

Intermediate Vocational Education, Agriculture 3

Intermediate Vocational Education, Medical Laboratory $\quad 3$

Academic Education and Higher Vocational Education, Theology 3

Higher Vocational Education, Medical and Non-medical

\begin{tabular}{ll} 
Laboratories & 3 \\
\hline
\end{tabular}

$\begin{array}{lc}\text { Higher Vocational Education, Air, Sea and Land Transport } & 3 \\ \text { Academic Education, Engineering } & 3\end{array}$

Current unemployment is an important indicator of the market position of an educational variety. Table 3.6 indicates which types of education have high, and which low, unemployment figures. ${ }^{15}$ Types with a high rate of registered unemployment are found at the bottom as well

15. The unemployment percentage is calculated as the number of registered unemployed in 1990 with training $X$ (source: Ministry for Social Affairs and Employment) divided by the sum of the number of registered unemployed in 1990 and the number of working persons 
as at the top of the educational system, but not, or hardly at all, at the I.V.E. or H.V.E. level. The 'general' education types are particularly severely hit by unemployment: Primary Education, Lower General Secondary Education, and Higher General Secondary Education, along with the 'softer' university courses (Fine Arts, Arts, and Social Sciences). The I.V.E. and H.V.E. types of education almost all have a favourable labour market position, with the exception of the sociocultural sector and fine arts.

However, the unemployment percentage only gives a partial insight into the market position of an educational variety. The kind of functions the school leavers occupy, and whether the levels of these functions match the qualifications acquired during the study, is at least as important. The extent to which qualifications are utilized was examined by first finding the average function level for the occupational classes in which the graduates of each educational variety work (taken from Huijgen (1989)). Then, for each educational variety, the percentage of those working in these occupations, but at a level below their education, was determined. ${ }^{16}$ The data is based on the labour force census of $1985 .{ }^{17}$ Table 3.7 shows which types of education had relatively high, and which low under-utilization in 1985 . These must be interpreted with some caution because the levels following Huijgen (1989) are determined for occupational classes, a classification that is not really sufficiently precise. This may produce a systematic distortion for individual types of education, in either direction.

Under-utilization is strongly related to the skill level. Some $45 \%$ of workers with an education at L.V.E. level experience under-utilization of their qualifications. At I.V.E. level this figure is $43 \%$, at the H.V.E. level $24 \%$, and at the academic level it is $14 \% .{ }^{18}$ Types of education with relatively high under-utilization are found at L.V.E., I.V.E., and H.V.E. levels. Between $50 \%$ and $90 \%$ of workers with these types of qualifications are in a function below their level of education. The sectors in which a lot of under-utilization occurs, are: Transport \& Harbour, Security (including police, firemen, etc.) and Community Care. It is notable that two higher

in 1989 (both with training X), times $100 \%$.

16. Using Huijgen's function scale (Huijgen, 1989) the under-utilization level for those with academic (WO) education is 5.5, for HBO training 4.5, for MBO training 3.5 and for LBO, 2.5.

17. Arbeidskrachtentellingen, 1985.

18. Due to slightly differing classifications, these percentages differ somewhat from the figures of Huijgen (1989). 
types of education: H.V.E. Commerce \& Administration and H.V.E. Non-medical Laboratory, also appear in the list.

Table 3.7. Types of education with high, and with low, under-utilization

\section{Higher under-utilization}

Type of education

under-utilization

$\%$ weighted

level of

functions
Lower Vocational Education, Security

Lower Vocational Education, Transport \& Harbour

Intermediate Vocational Education, Police, Fire \&

Defense Force

Lower Vocational Education, Community Care, Hotel \&

Catering

Intermediate Vocational Education, Transport, Harbour \&

Telecommunications

Higher Vocational Education, Police, Fire \& Defense

Forces

Intermediate Vocational Education, Community Care

Higher Vocational Education, Commerce \& Administration

Higher Vocational Education, Non-medical Laboratory

Higher General Secondary Education
2.4

2.2

3.1

3.3

3.8

3.3

4.5

4.8

3.8

Low under-utilization

Type of education

under-utilization

$\%$ weighted

level of

functions

Academic Education, Pharmacy

Academic Education, Veterinary \& Medical Sciences \&

Dentistry

Higher Vocational Education, Nursing \& Physiotherapy etc.

Academic Education, Teacher training

Academic Education, Arts

Academic Education, Mathematics \& Natural Sciences

Higher Vocational Education, Fine Arts

Higher Vocational Education, Teacher training

Intermediate Vocational Education, Medical Laboratory

Higher Vocational Education, Theology

4

4

6

7

9

9

11

12

12

13
6.8

6.8

5.2

6.4

6.2

6.5

5.3

5.8

4.2

5.7

The types of education with relatively little under-utilization are especially A.E. and H.V.E. courses, especially those aimed at a professionalised market sector: health care, institutional religion and education. These are market sectors with strong regulations governing access to 
the profession: competition from other categories of labour supply is impossible or impracticable. These types of education have a strong market position in that respect, though they are more vulnerable to quantitative fluctuations in the demand-supply relationship (see the high unemployment percentages for A.E. Arts, in table 3.6).

Table 3.8. Types of education with limited alternative occupations at a matching function level, and those with extensive alternatives

Few alternatives

Type of education

$\mathrm{GH}$

Lower Vocational Education, Security

Lower Vocational Education, Transport \& Harbour

Intermediate Vocational Education, Police, Fire \& Defense Forces

0.38

Academic Education, Teacher training

0.47

Higher Vocational Education, Theology

0.51

Intermediate Vocational Education, Para-medical services

0.51

Lower Vocational Education, Community Care, Hotel \& Catering $\quad 0.54$

Academic Education, Veterinary \& Medical Sciences \& Dentistry 0.55

Academic Education, Theology

0.55

Higher Vocational Education, Police, Fire \& Defense Forces

0.59

\section{Extensive alternatives}

Higher Vocational Education, Business Administration Technology

0.91

Academic Education, Mathematics \& Natural Sciences

0.91

Higher Vocational Education, Agriculture

Academic Education, Economics and Business

Administration

Academic Education, Agriculture

0.89

Intermediate Vocational Education, non-medical Laboratory

0.86

Academic Education, Econometrics \& Business Administration

Technology

0.86

Intermediate Vocational Education,Commerce \& Administration

0.86

Thus it is important to know what alternative possibilities school leavers have on the labour market. A type of education which allows many alternative possibilities is less vulnerable to fluctuations in the labour market than one that has no alternative possibilities at all. The dispersion of each type of education among occupational classes was therefore examined. The Gini-Hirschmann coefficient was chosen as a dispersion standard: this has the value 0 when all persons with a certain educational background are concentrated in one occupation, and 1 when these persons are equally spread over all occupational classes (see De Grip, Heijke and Dekker, 
1989). The calculations were based on the labour force census of 1985 and relate to dispersion over occupational classes with a function level matching the education. The possibility of shifting to an occupation with a lower function level is not considered: this is not a 'real' alternative. It is important to note that the standard that is used deals with proven alternative occupations, not potential alternatives.

Types of education with limited alternative possibilities occur at all skill levels, especially in professionalised and semi-professionalised sectors, such as security, health care, education and institutional religion. The types of education with relatively wide alternative possibilities are especially the technical, agricultural and commerce \& administration courses at H.V.E. and academic level.

If one looks at these data again, the following picture appears. ${ }^{19}$ In the first place, a group of types of education can be distinguished that are oriented to professional and semi-professional market sectors. These types of education suffer little competition from other types of education in their own sector, but they also have few alternative possibilities in other sectors or lower functions. Depending on the relationship of demand and supply in their market sector, they may have a good labour market position (for instance A.E. Veterinary \& Medical Sciences \& Dentistry and A.E. or H.V.E. Theology) or, in contrast, they may have a relatively weak labour market position (A.E. Arts, for instance). A second group includes some types of education that are directed at the top end of the labour market. These are characterized by a very good labour market position: the unemployment figure is very low, there is relatively little under-utilization and there are relatively many alternative occupations. They are mainly university qualifications, such as the A.E. Engineering, Mathematics \& Natural Sciences, Economics \& Business Administration, and Econometrics \& Business Administration Technology. A third group of types of education relate to the market for vocational trades. The technical, agricultural and laboratory education offered at intermediate and higher level can be placed in this group. Unemployment among these types of education is very low, the under-utilization is relatively low and the alternative possibilities are rather high. Finally, a group of types of education can be distinguished which can be located at the bottom end of the labour market: the alternative possibilities are very high, but this is due to the fact that for most functions no specific qualifications are required. The fact that the under-utilization percentages are not bad has to do with bottom effects. The poor market position of these types of education is therefore expressed primarily in high unemployment figures. Lower General Secondary Education, Primary Education alone, and some L.V.E. types of education fall in this last group.

19. As of the coming year, it is intended to summarise the market position of training varieties with a composite indicator. 
$\ldots$ 


\section{DEVELOPMENTS IN THE QUALIFICATION STRUCTURE AND THE EMPLOYMENT STRUCTURE}

\subsection{Introduction}

This section will examine changes in the qualification structure of school leavers between 1979 and 1988, along with the forecasts to 1994 . Changes in the employment structure in the period 1979-1989, and developments which are expected to occur in the forecasting period 19891994, will also be examined. Subsection 4.3 will discuss shifts in the occupational structure and 4.4 will look at changes in the educational structure.

\subsection{Changes in the qualification structure}

The qualification structure of the working population is an important determinant of technological development. The education of the population determines, to a large extent, the innovative capability of society and it is also an important determinant of the rate at which technological developments take place. Shifts in the flow of school leavers are especially important for the development of the qualification structure of the working population. Figure 4.1 shows how the flow of graduates has developed, in terms of level, in the period 1979-1988, and what the forecasts are for the period 1988-1994. The figures relate exclusively to those graduating from a course with a diploma, because, for the period 1979-1988, there is no information on the highest certificate from previous education held by those who leave their current course without graduating. In the educational levels discussed here, these 'drop-outs' are therefore left out. Since the figures for the forecast outflows and the available data on the realized outflow do not entirely match, the analysis will focus on trends rather than absolute numbers. ${ }^{20}$

After a slight decline in the early eighties, the total number of qualified school leavers increases again until 1988. In total, the number of qualified school leavers increased by $12 \%$ in this period. The big losers in the period 1979-1988 are Lower General Secondary Education (-65\%), Higher General Secondary Education (-35\%), and Lower Vocational Education (L.V.E., -25\%). The flow of graduates from Academic Education (A.E.) almost triples in this period, with an explosive increase in the academic year 1987-1988. Intermediate Vocational Education (I.V.E.) is also a clear growth category with an increase of $85 \%$ in the period 1979-1988. The flow from Higher

20. For the year 1987-1988 historical figures, taken from the Educational flow matrices of the Central Bureau for Statistics, and forecasts taken from the SKILL estimate of 1990 are both presented. The two figures do not entirely match: most notably, the number of school leavers at IVE level is underestimated in the forecasts. 
Vocational Education (H.V.E.) increased by $14 \%$ in the same period.

In the forecast period, a growth of $36 \%$ is forecast for H.V.E. For all the other types of education the numbers graduating with a qualification decrease, especially for L.V.E. (-36\%), Lower General Secondary Education (-26\%) and Higher General Secondary Education (-17\%). In all of these three types of education the downward trend of the eighties is expected to be continued. The forecasts for I.V.E. and A.E. are for declines in absolute numbers of $8 \%$ and $5 \%$ respectively, more or less in line with a decline in the total flow of school leavers of $8 \%$ over the forecast period.

Figure 4.1. Outflow of the educational levels

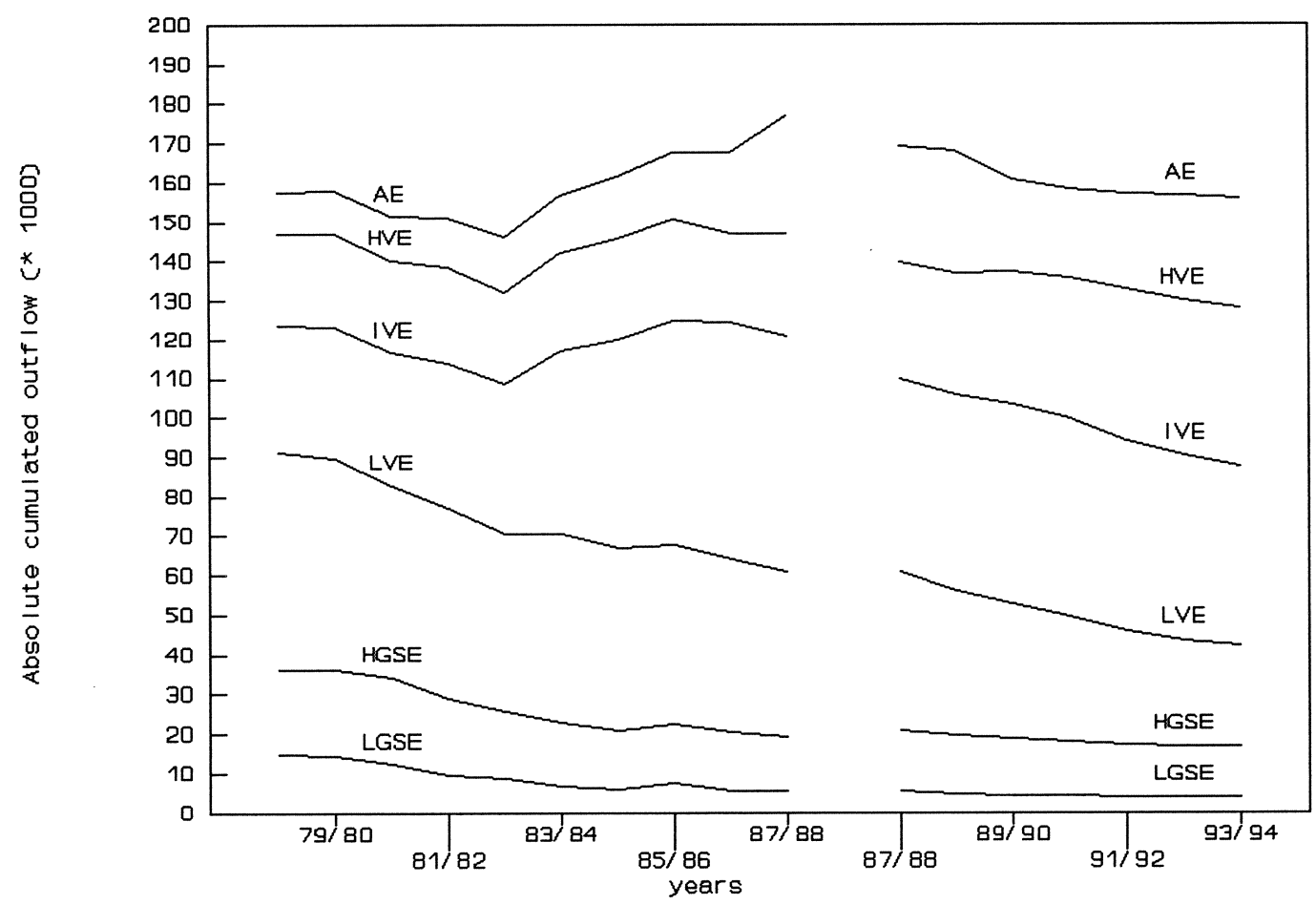

Legend:

$\mathrm{AE}=$ Academic Education

HVE = Higher Vocational Education

IVE = Intermediate Vocational Education

LVE = Lower Vocational Education

HGSE = Higher General Secondary Education

LGSE = Lower General Secondary Education 
Figure 4.2. Share of Higher Education in total outflow

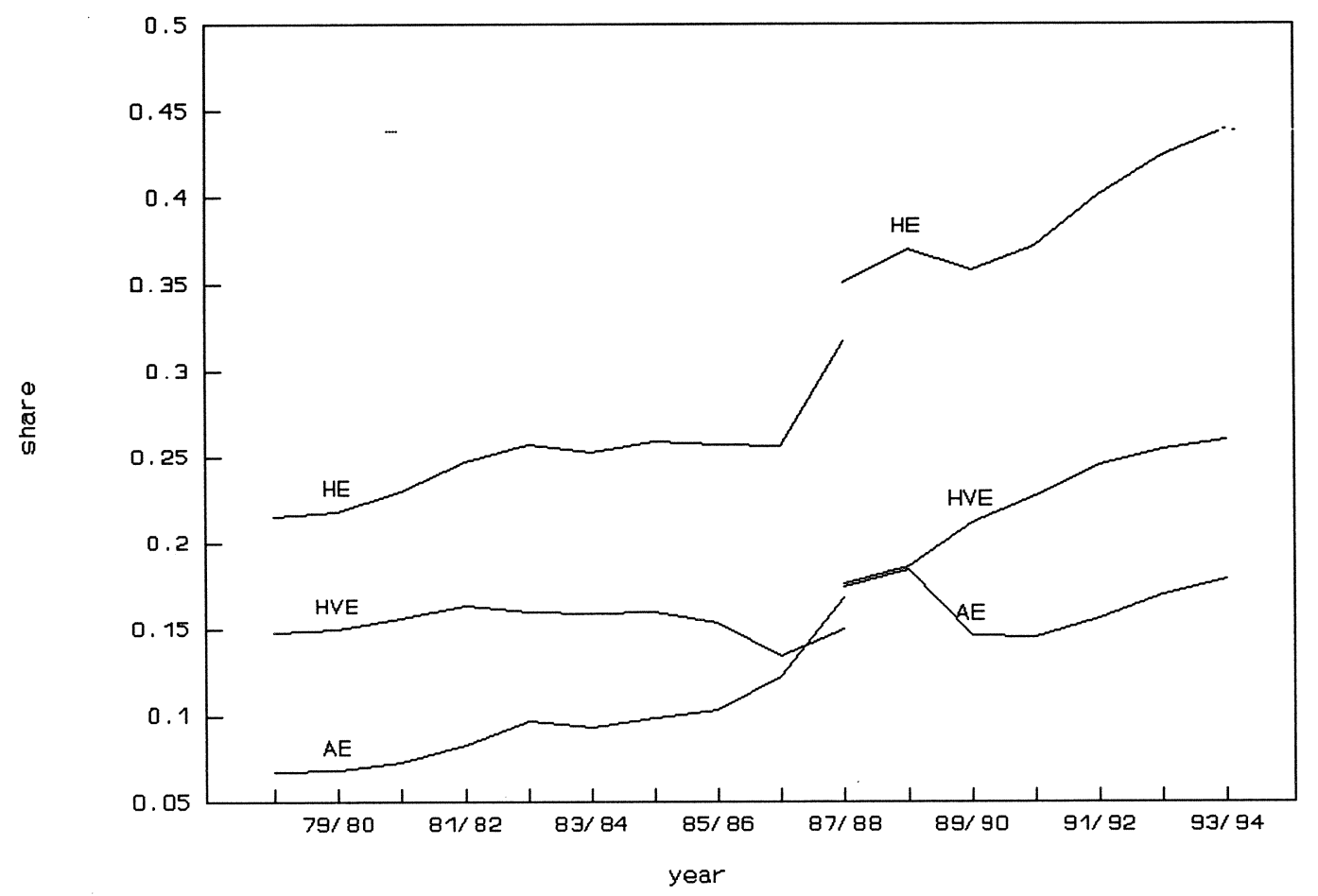

Legend:

$\mathrm{HE} \quad=$ Higher Education

HVE = Higher Vocational Education

$\mathrm{AE} \quad=$ Academic Education

Source: CBS/ROA

The changes in the flow of people with tertiary education come even more to the fore when we look at the changes in the share of this group in the total flow of those leaving education with a qualification. Figure 4.2 clearly shows that those with tertiary education form an increasing portion of the total flow during the entire period: between 1979 and 1988 their share increased by 10 percentage points, and in the period after that by 9 points. The growth in the first period can be attributed especially to the growth in academic education, and that in the second period to the H.V.E. types of education. For 1994 the forecast is that $44 \%$ of those leaving education with a qualification will come from H.V.E. or academic education, double the percentage in 1979. The question is, whether so many tertiary graduates can also be completely absorbed by the market. Section 3 has already shown that the higher types of education in particular have unfavourable labour market prospects. In the period $1989-1994$ it is expected that $27 \%$ of the total outflow (with or without qualifications) will consist of those with tertiary education (16\% H.V.E. and $11 \%$ 
academic education). But only $18 \%$ of the total number of job openings are explicitly intended for these graduates: $14 \%$ for H.V.E. graduates and $4 \%$ for academic education.

The number of people entering the labour market without any occupational qualification is also an important determinant of the level of education of the labour force. A marked decrease in this category of school leavers (Lower and Higher General Secondary Education and L.V.E.) could be deduced from figure 4.1 above. In $197957 \%$ of all those leaving education with a qualification had had no more than General Secondary Education or L.V.E. In 1988 this proportion had decreased to $34 \%$. In the period $1988-1994$ this share will decrease further to $25 \%$. Of course this is strongly related to the growth of tertiary education as shown in figure 4.2. However, in addition to that, the proportion of those leaving secondary education without any occupational qualification has also decreased (see figure 4.3).

Figure 4.3. Share of Intermediate Vocational Education and apprenticeship training in total outflow of Secondary Education

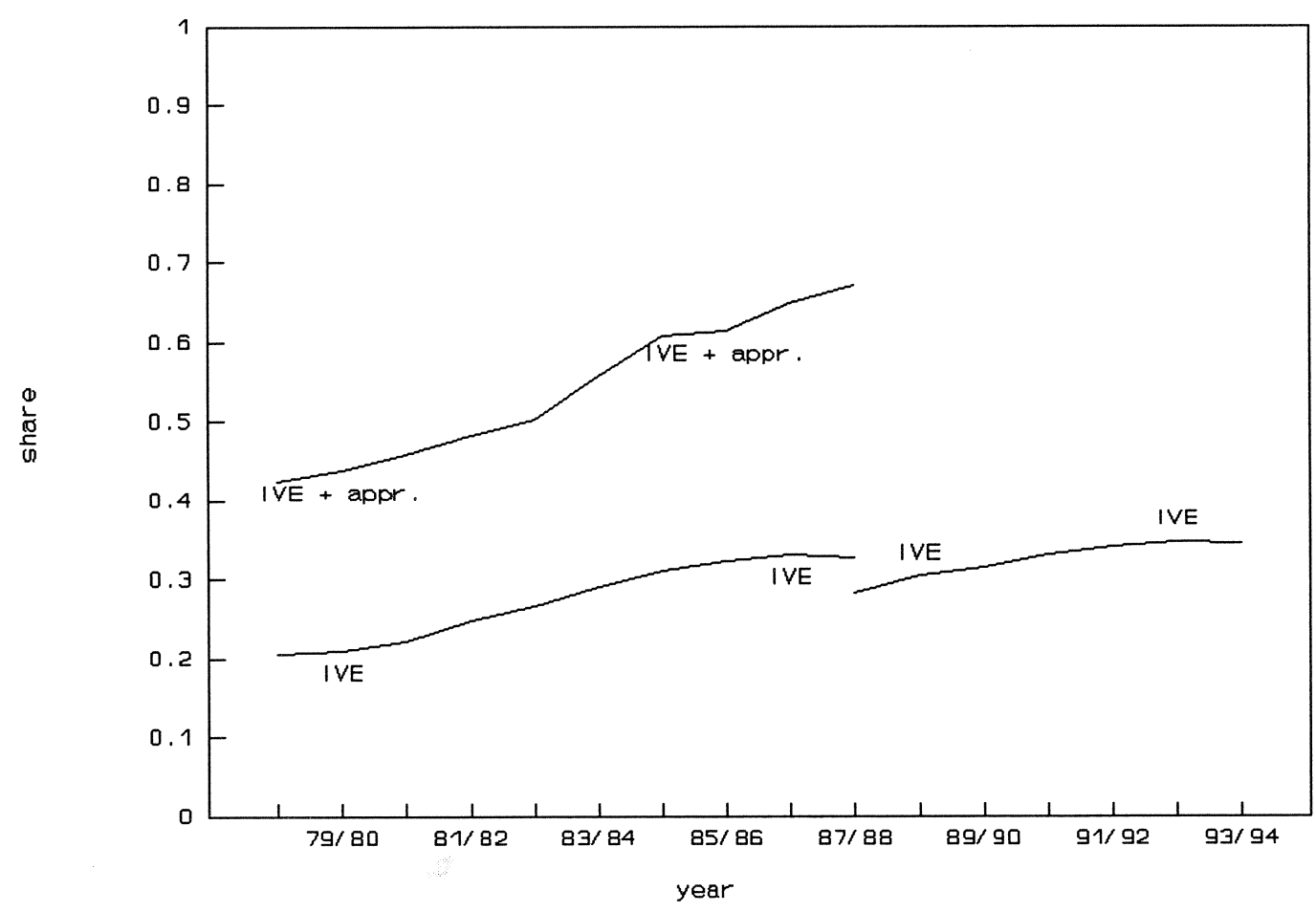

Legend:

IVE = Intermediate Vocational Education

appr. = Apprenticeship Training and Short Intermediate Vocational Education 
The proportion of those leaving education with a qualification who had I.V.E. or apprenticeship training increased by $25 \%$ in the period 1979-1988 (figure 4.3). For the period 1988-1994 a further $7 \%$ growth in this share is expected for I.V.E. Unfortunately there are no such forecasts for apprenticeship training. Overall, we can conclude that the average qualification of those leaving a course with the qualification, and entering the labour market, has increased markedly, due to the growth of tertiary education on the one hand and to the decreasing numbers of school leavers with only General Secondary Education or L.V.E. on the other hand.

Figure 4.4. Share of technically educated in total outflow of Higher Education and Intermediate Vocational Education

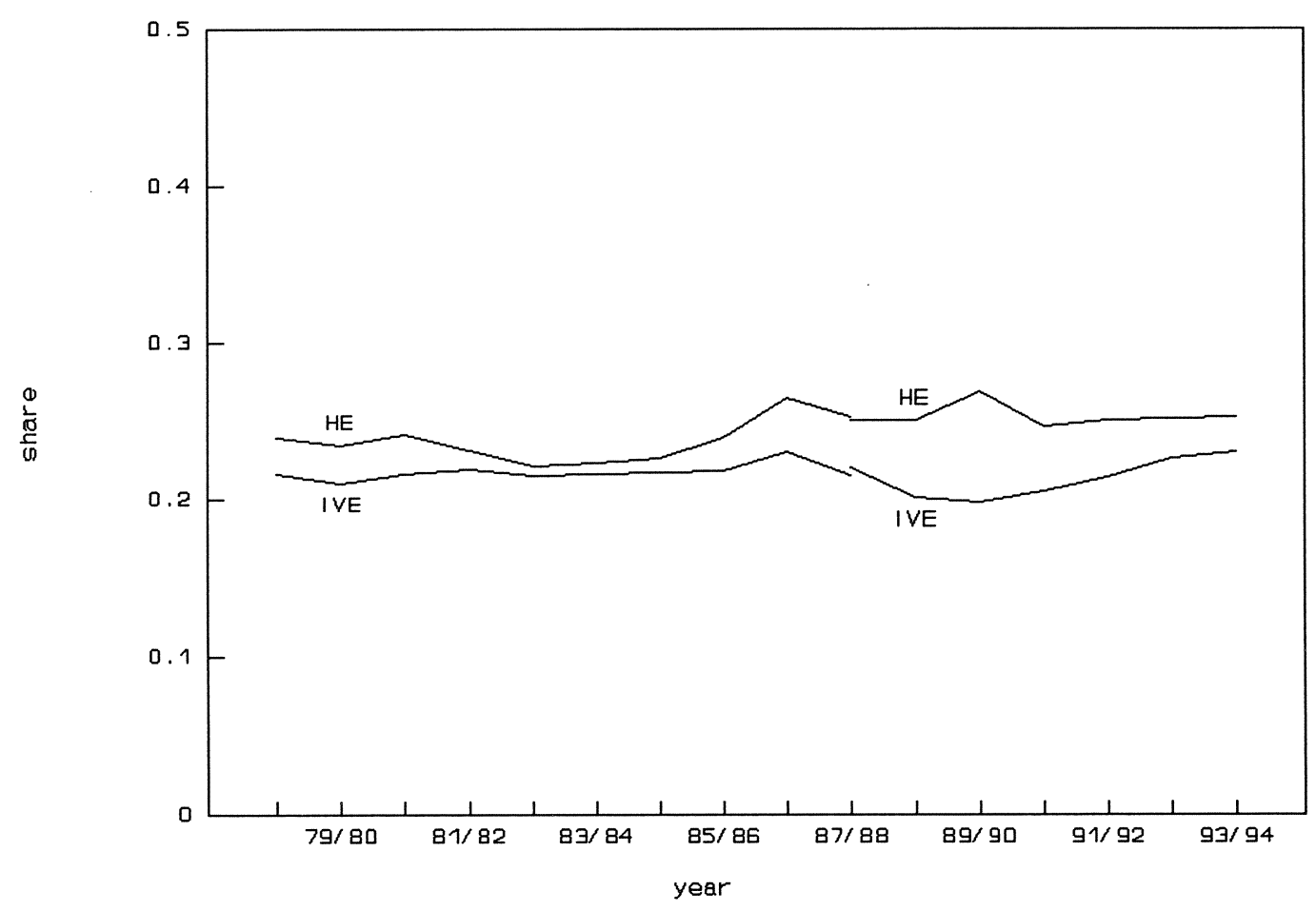

Legend:

$\mathrm{HE} \quad=$ Higher Education

IVE = Intermediate Vocational Education

Source: CBS/ROA

The educational level of the labour force is determined not only by the level of education they have, but also by the field of education. Figure 4.4 shows how the share of technical education in the flow from I.V.E. and tertiary education, respectively, has developed. This share is very stable for 
both levels: for I.V.E. it fluctuated around $22 \%$ and for tertiary education around $25 \%$. The share of intermediate and higher technical education in the total outflow increases, but this is exclusively due to the growth of I.V.E. and tertiary education. Within these skill levels the relative importance of technical education is very constant. Overall, this outflow seems to be only just sufficient for the needs of the labour market. Intermediate and higher technical education accounted for $13 \%$ and $5 \%$ of the total (graduate and drop-out) numbers, respectively. Of the total number of job openings, $12 \%$ and $4 \%$, respectively, are for these two categories.

\subsection{Changes in the occupational structure}

We have already seen, in section 2, how the employment situation by sectors changed between 1979 and 1989, and is expected to develop until 1994. The recession in the early eighties was seen to have had a negative effect especially on the textile and clothing industry, the lumber and construction materials industry and on construction. But the non-commercial sector, especially the medical and veterinary services and the 'miscellaneous' non-commercial services, showed a growth of employment in exactly this period. In the second half of the eighties, the sectors which appeared to profit strongly from economic growth were miscellaneous tertiary services and house construction, the lumber and construction materials industry, trade, the building industry and the paper and printing industry. For the forecasting period, a slight decrease is expected in the number of workers in the food and drink industry, the textile and clothing industry and agriculture and fishing. Growth sectors are trade, other tertiary services and house construction, the banking and insurance industry, the chemical industry, the transport sector and the non-commercial sector.

Using a shift-share analysis, we have examined how the occupational structure changes during the three periods we have distinguished (see also De Grip, 1987, and Teulings and Webbink, 1990). Three effects can be distinguished. In the first place, a sector structure effect may occur. That is, the employment situation in an occupational class may change as a result of a change in the total employment situation in the sectors in which the members of the class in question are working. In the second place, an occupational structure effect can be distinguished. This is an increase or decrease of employment for an occupational class as a result of the increasing or decreasing importance of the occupational class in the economic sectors in which they are working. In the third place, an interaction effect is possible. For instance employment might grow as a result of the combination of an increase in the employment share of the occupational class in a certain sector and an increase in the total employment level in this sector. Table 4.1 indicates how big the total 
change in the occupational structure in the three periods has been, ${ }^{21}$ broken down into the portions attributable to the sector effect, the occupational effect and the interaction effect.

Table 4.1. Relative importance of the occupational structure effect, the sector structure effect and the interaction effect

\begin{tabular}{lrccc}
\hline & total effect & sector effect & occupational effect & interaction effect \\
\hline $1979-1985$ & 13.5 & 10.1 & 8.8 & 1.4 \\
$1985-1989$ & 8.6 & 5.7 & 6.2 & 0.6 \\
$1989-1994$ & 6.1 & 2.8 & 5.1 & 0.3 \\
\hline
\end{tabular}

Table 4.1 lists the absolute values of the individual shifts in employment share for all occupational classes. The shift in overall dynamics is noteworthy. The total shifts in the employment structure by occupational classes are expected to be considerably less in the first half of the nineties than in the eighties. However, it should be kept in mind that, for the period 1989-1994 and part of the period 1985-1989, we are dealing with predicted figures. Because of the forecasting methodology the total movement is underestimated: where there are movements in the analysis period which are below the significance threshold the forecast is based on the assumption of constant shares. The shifts in the first half of the eighties are therefore the largest. The underlying structural shifts are in fact larger than would appear from the sum of total effects, because the occupational and sector effects in part compensate for each other. The sum of the occupational and sector effects is considerably bigger for each period than the total effects. Leaving aside the forecasting period, the sector and occupational effects are almost equal to each other. The interaction effect is very limited in all cases.

To give a more exact picture of the individual effects for certain occupational classes, figure 4.5 outlines the shifts underlying the growth of the ten occupational classes with the highest forecasts for absolute growth in employment in the period 1989-1994 (see table 2.2).

The sector effect appears to lead to a noteworthy shift in the employment share of only a few groups. A positive sector effect occurs for shop assistants (code 48), working proprietors in the retail trade (code 43), the medical, dental, pharmaceutical and veterinary professions and their assistants (code 06/07) and bookkeepers and cashiers etc. (code 33). No noteworthy negative sector effects occurred in the occupational classes under discussion.

21. This is defined as the sum of the absolute shifts in the share of an occupational class in the total employment. 
Figure 4.5. Shift-share of occupations 1989-1994

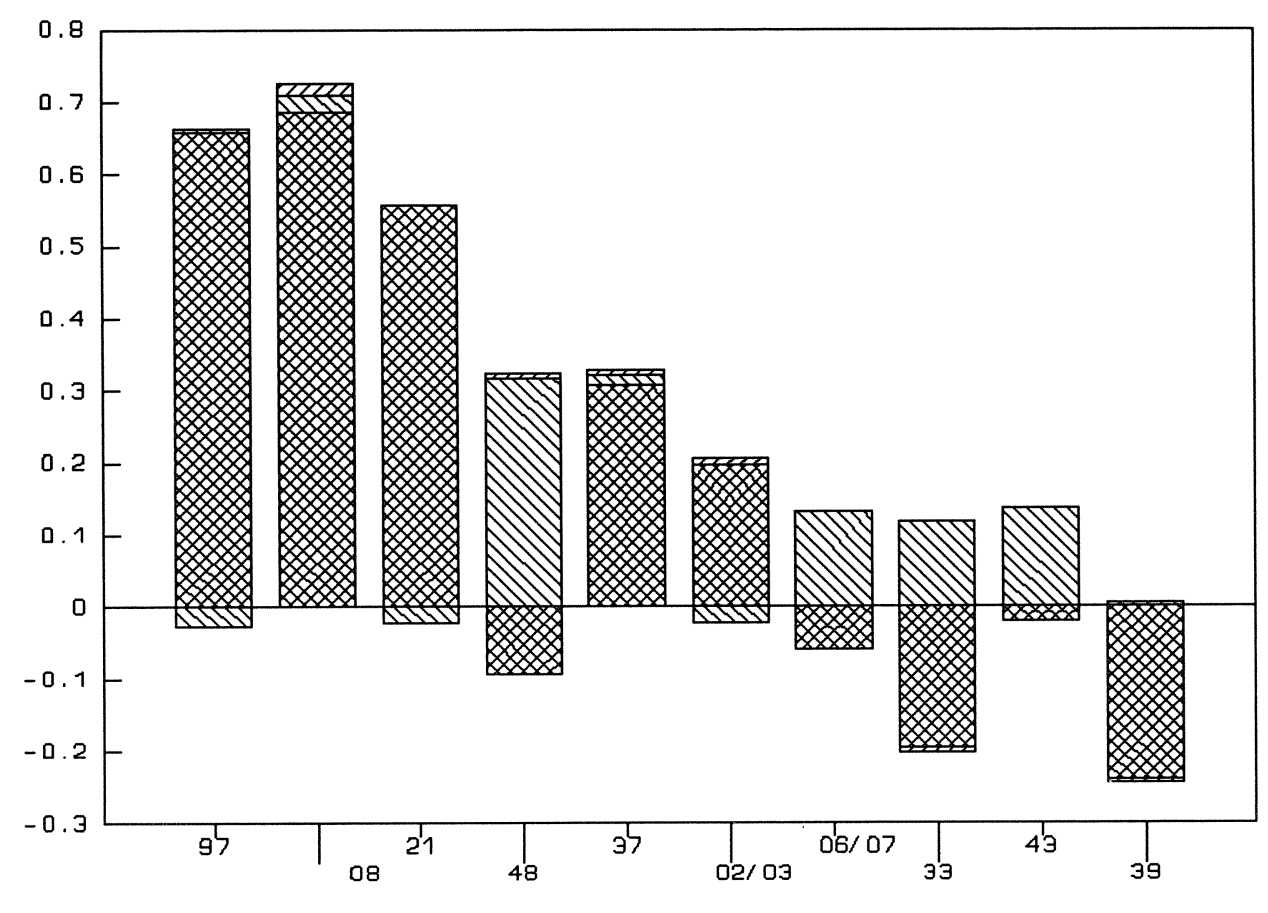

occupational effect sector effect

Source: ROA

A negative occupational effect is noted for bookkeepers and cashiers etc. (code 33) and for miscellaneous administrative functions (code 39). These are large occupational classes with high absolute employment growth but a less than average growth in percentage terms, (that is, with a decreasing employment share). A negative occupational effect is also expected for shop assistants (code 48) and medical, dental, pharmaceutical and veterinary professions and their assistants (code 06/07). On the other hand, a strong positive occupational effect is expected for the groups freight handlers, packers, and construction machine operators (code 97), programmers, statisticians, and assistants (code 8 ) and company directors and senior executives (code 21). A clearly positive occupational effect is also expected for postal workers and mail clerks (code 37) and architects, engineers and related technicians (code 02/03). For all ten occupational classes the interaction effects are small or very small. 


\subsection{Shifts in the educational structure}

It is also possible to give a more detailed picture of the various components of the changes in the employment shares of the various types of education. Once again we can distinguish three effects. In the first place, an occupation/sector effect is possible, which represents the shifts in employment shares caused by shifts in the occupational structure and/or the sector structure. In the second place, there may be an educational structure effect: the shifts in the employment share which result from changes in the share held by a type of education in the employment within a given occupation/sector combination. There may also be an effect due to the interaction of the first two effects.

Table 4.2 gives a picture of the total changes in the educational structure of employment and splits it up according to the occupation/sector effect, the educational effect and the interaction effect for the periods 1979-1985, 1985-1989 and 1989-1994. In each case the absolute values of the shifts are aggregated.

Table 4.2. Relative importance of the occupation/sector structure effect, educational structure effect and interaction effect

\begin{tabular}{ccccc}
\hline Period & $\begin{array}{c}\text { total } \\
\text { effect }\end{array}$ & $\begin{array}{c}\text { occupation/sector- } \\
\text { effect }\end{array}$ & $\begin{array}{c}\text { educational } \\
\text { effect }\end{array}$ & $\begin{array}{c}\text { interaction } \\
\text { effect }\end{array}$ \\
\hline $1979-1985$ & 25,2 & 10,1 & 19,5 & 4,0 \\
$1985-1989$ & 12,6 & 3,2 & 11,8 & 1,3 \\
$1989-1994$ & 8,6 & 1,7 & 7,9 & 0,2 \\
\hline
\end{tabular}

The table shows that the total movement in the educational structure of employment is expected to decrease considerably. This also applies to each of the three effects considered separately. As has already been indicated in subsection 4.3 , this decrease is partly related to the forecasting methodology. In all three periods the educational effect appears to be the main cause of the shifts in the educational structure of employment. The influence of the occupation/sector effect seems to be less strong. In all cases the interaction effect is very small.

The strong educational structure effect cannot automatically be interpreted as a displacement effect. It is possible that a shift to other function levels took place within an occupational class. Because of the classification of occupations used this is not made entirely clear in the shift-share analysis. The combined occupation/sector effect indicates that the shift in the educational structure is at least partly led by the demand side. 
Figure 4.6. Shift-share of educational classes 1989-1994

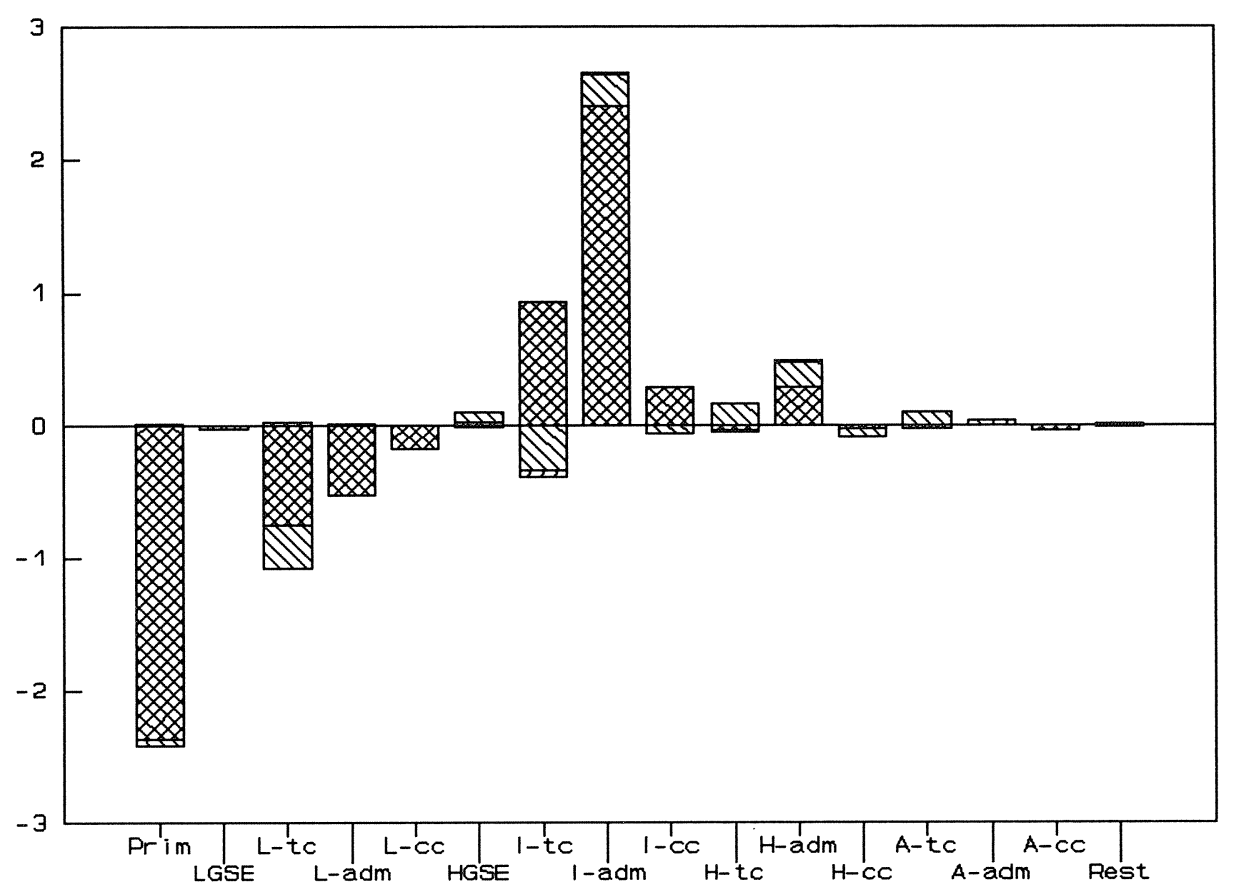

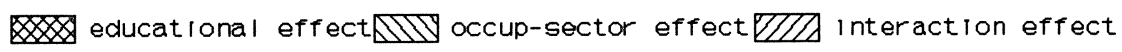

Legend:

$\begin{array}{ll}\text { Prim } & =\text { Primary Education } \\ \text { LGSE } & =\text { Lower General Secondary Education } \\ \text { L-tc } & =\text { L.V.E. - technical } \\ \text { L-adm } & =\text { L.V.E. - administration } \\ \text { L-cC } & =\text { L.V.E. - community care, hotel catering } \\ \text { HGSE } & =\text { Higher General Secondary Education } \\ \text { I-tc } & =\text { I.V.E. - technical } \\ \text { I-adm } & =\text { I.V.E. - administration } \\ \text { I-cc } & =\text { I.V.E. - community care, hotel catering } \\ \text { H-tc } & =\text { H.V.E. - technical } \\ \text { H-adm } & =\text { H.V.E. - administration } \\ \text { H-cc } & =\text { H.V.E. - community care, hotel catering } \\ \text { A-tc } & =\text { A.E. - technical } \\ \text { A-adm } & =\text { A.E. - administration } \\ \text { A-cc } & =\text { A.E. - community care }\end{array}$

Source: ROA

Figure 4.6 shows which shifts underlie the forecast changes in employment for the different educational categories. It is based on a broader educational classification of the kind also used by the Central Planning Bureau (Kuhry and Van Opstal, 1987). This has five skill levels (primary education, I.V.E., H.V.E. and academic education) and four educational fields (general, technical, 
administrative and community care). The types of education that do not fall under these categories are put together in a remainder category.

The figure shows that the biggest employment decrease is expected to occur for educational categories at the lowest level. On the other hand, the biggest employment growth is expected to occur for I.V.E. and H.V.E. The percentage growth in employment for academic education is expected to be slight.

If we look at the different components of the changes in employment levels, the great importance of the educational effect is very clear. For those who have not completed any secondary education (having only primary education) the educational effect is almost entirely responsible for the expected decrease in employment. There is also a strong negative educational effect for L.V.E. courses in the technical and commercial-administrative fields. Intermediate level education in the commercial-administrative field has the strongest positive educational effect, followed by intermediate level education in the technical and community-care fields. A positive educational effect is also expected to occur for H.V.E. courses in the commercial-administrative field.

The technical types of education at lower and intermediate level have the largest negative occupation/sector effects. At the intermediate level however, this negative effect does not outweigh the positive educational structure effect already mentioned, so that on balance there is an increase in the employment share. The commercial-administrative types of education at I.V.E. and H.V.E. level are the types of education for which the biggest positive occupation/sector effect is expected, followed by technical education at H.V.E. and academic level. These higher technical types of education thus present us with a mirror-image of the picture for the technical types of education at a lower and intermediate level, highlighting the shift in the occupational structure towards higher skilled labour force in technical fields.

To summarise: a number of conclusions can be drawn about the shifts in employment and educational structures. In the first place, there is more movement in the labour market than would appear from a broad analysis, because the various types of effects can partly compensate for each other. In the second place it would appear that, leaving aside the forecasting period, the sector effect is almost as strong as the occupation effect. The occupation effect is demonstrable especially in the growth occupations. Thirdly, the change in the educational structure appears to be caused largely by changes in the shares of various types of education within a given occupational class. Nevertheless there are also demand-led factors. 



\section{SEX, EDUCATION AND THE LABOUR MARKET}

\subsection{Introduction}

In this section the relation between sex, education, and the labour market is the central theme. ${ }^{22}$ The primary goal is to give a description of the differences between the positions of men and women on the labour market. A number of recent sex-specific labour market developments are discussed, and forecasts of the labour market prospects of some typical women's occupations and women's types of education are presented.

Subsection 5.2 will deal with the differences in labour market participation, part-time labour, and unemployment between men and women. Subsection 5.3 explains the segregation of working men and women so far as their educational qualifications and current occupation go. Next, in subsection 5.4 , the present and future labour market positions of those practising their trade in typical women's occupations are outlined. Subsection 5.5 closes with a description of a number of the labour market characteristics of traditional women's types of education.

\subsection{Participation rate, part-time labour and unemployment}

Since the sixties, the percentage of women who present themselves on the labour market has strongly increased (see Rapportage Arbeidsmarkt, 1990). This participation in the labour market is usually expressed as the so-called 'participation rate' or the 'participation percentage'. In the past decades the participation rates of men and women have grown significantly closer. In 1960 the participation rate ${ }^{23}$ for men was $90 \%$ and for women $26 \%$, whereas in 1987 the figures were $76 \%$ and $44 \%$ respectively (Rapportage Arbeidsmarkt, 1990).

The participation rate of men has gone down, due on the one hand to increasing participation in education by younger men and on the other hand to an increase in the number of (older) men who are incapacitated or retire early. The participation rate for men between 25 and 50 years of age has hardly changed. For women, on the other hand, the growth in participation occurred especially in the middle age-groups and for married women in particular. This is the 'fertile' phase of life for

22. For a thorough description of the relation between sex, education and the labour market, see Van de Loo and Van der Velden (1991).

23. This relates to the proportion of the population aged between 15 to 65 who are in the labour force. 
married women (Bruyn-Hundt, 1988).

Table 5.1. Participation rates ${ }^{24}$ by sex and level of education in 1979 and 1985

\begin{tabular}{lcccc}
\hline & \multicolumn{2}{c}{ Men } & \multicolumn{2}{c}{ Women } \\
Level of education & 1979 & 1985 & 1979 & 1985 \\
\hline & & & & 22,8 \\
Primary Education & 81,8 & 76,0 & 46,3 & 45,7 \\
Lower General Secondary Education & 94,3 & 89,2 & 36,5 & 42,7 \\
Lower Vocational Education & 92,9 & 90,6 & 58,8 & 65,6 \\
Higher General Secondary Education & 96,4 & 93,9 & 54,3 & 59,2 \\
Intermediate Vocational Education & 95,6 & 93,0 & 64,9 & 73,0 \\
Higher Vocational Education & 97,0 & 94,3 & 78,8 & 85,9 \\
Academic Education & 98,6 & 96,5 & & \\
\hline
\end{tabular}

Source: CBS/ROA

There is a positive relationship between the participation rate and the level of education (see table 5.1). Especially for women, a high level of education is coupled to a relatively high participation rate. The declining participation of men and the growing participation of women can also be observed in this table. With the exception of women whose highest level is Lower General Secondary Education, this trend appears at all educational levels. The declining participation of men is relatively greater among men with a low level; the increased participation of women on the other hand was relatively stronger among women with secondary and tertiary education.

In formulating its forecasts of labour supply, the Central Planning Bureau also determined the future participation rates for men and women (Kuhry and Van Opstal, 1987). They extrapolate the trend for growing participation by women to $58 \%$ in the year 2000 , whereas the participation rate for men is frozen at the level of 1985 , that is, at $89 \%$.

Although the participation rate is usually used as key indicator of changes in the female labour supply, this only gives a partial insight into the dynamics of labour supply. The 'employment share' would serve the end better. ${ }^{25}$ Because women work in part-time jobs more often than men and because the registered unemployment among women is higher than that among men, the employment share for women is smaller than the participation rate. For example, women made up

24. The participation degree here concerns the labour force as the percentage of the potential labour force (i.e., persons between the ages of 15 and 65, who are not students).

25. The proportion of the potential labour force who are actually employed. The employment level is expressed in labour years to allow for part-time employment. 
$34 \%$ of labour force in 1983 , but their employment share was only $26 \%$ (Bruyn-Hundt, 1988). Moreover, despite the considerable increase in the participation rate among women since the early sixties, women's employment share in this period increased considerably more slowly than their participation rate. In the period 1977-1985 the employment volume of women grew by $16 \%$, whereas the number of working women in the same period increased by over $29 \%$ (Huijgen, 1989).

This picture is confirmed when the weekly working hours of women working in salaried employment in 1979 are compared to those in 1985. In 1979, 56\% of these women worked in a full-time job, whereas in 1985 only $46 \%$ had a full working week. On the other hand, the percentage of women working part-time increased considerably during this period.

Figure 5.1. Women and men employed in working hours

Women

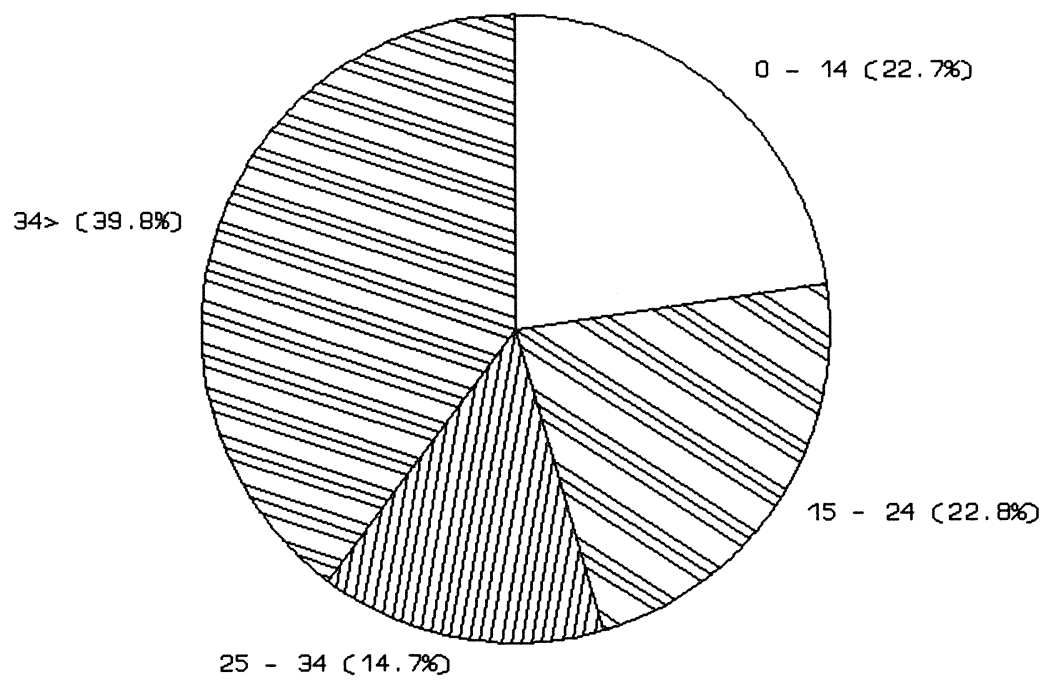




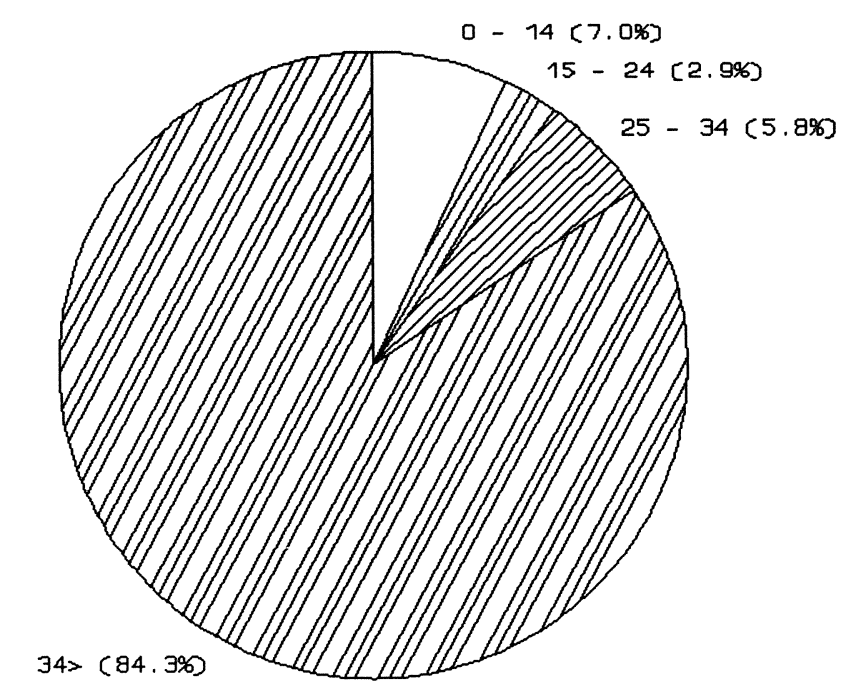

Source: CBS/ROA

The fact that part-time work is women's work can also be seen from figure 5.1, which indicates the hours per week worked by men and women. Almost $85 \%$ of the men have a full-time job, whereas not even $40 \%$ of the women have full-time employment. Those men who do work parttime appear to have mainly very small part-time jobs. These are especially school pupils and students with a job alongside their study.

The differences between the employment share and participation rate measures of male and female participation are determined not only by the differences in part-time work but also, in equal measure, by the differences in their recruitment and redundancy situation. For example, unemployment for women is proportionally higher than for men. It also appears that women gained less from the decrease in unemployment: whereas the number of unemployed men decreased by almost a quarter between 1988 and 1990, unemployment among women decreased by only $13 \%$. This difference between the sexes is related in particular to short-term unemployment of less than one year. Between 1988 and 1990, short-term unemployment among men decreased three times 
as fast as that among women, while long-term unemployment decreased for men and women at almost the same rate (Rapportage Arbeidsmarkt, 1990).

\subsection{Educational and occupational segregation}

As a rule, sex-specific segregation is considered only in terms of the horizontal occupational segregation. An important component of segregation is thus left out. Since there is a strong relationship between education and occupation, the total occupational segregation can be split into two components. In the first place, during education, there is a pre-selection of men and women into education for some kinds of qualifications. After that there is a second selection process regarding occupational choice and career paths in the course of working life (Groot, 1990).

In this subsection the educational segregation ${ }^{26}$ and occupational segregation will be discussed. For both forms of segregation, two segregation indices will be used. Both indices can have values between 0 and 100. The indices (s) are equal to the sum of the percentages of the male, and of the female, labour force that would have to change their occupation or education in order to end all segregation. The corrected indices indicate the percentage of the entire labour force that would have to change their occupation or education to end segregation, under the restriction that the distribution of the total labour force over the occupation or educational categories remains unchanged (see also Siegers, 1979 and Groot, 1990).

Changes in the educational segregation and occupational segregation of men and women can be split into three components (Van Mourik and Siegers, 1988):

* changes as a result of alterations in the share of women in the active labour force;

* changes as a result of alterations in the distribution of the total labour force by educational backgrounds and occupations;

* changes as a result of alterations in the numerical relation between men and women within certain educational backgrounds and occupations.

Alterations in index $s$ are the result of changes in the last two components of the segregation. The changes in index $S$ are the result of developments in index $S$ plus the first of these components.

Educational segregation between men and women is related in particular to the field in which they

26. The training segregation is here discussed using the active labour force as a base, because in this way the relationship between training segregation and occupational segregation can be analyzed. As of next year however, training segregation will also be calculated using the flow from full-time education as a base. 
trained. This appears from the educational segregation indices $s$ and $S$ in table 5.2, where the types of education are distinguished according to level $^{27}$ and field of study. ${ }^{28}$

Table 5.2. Educational segregation indices in 1985, in percentages

Educational segregation: 4 levels Educational segregation: 5 fields
4,6

41,5
S

2,1

18,7

Source: Groot, 1990

Women appear to be over-represented in the nursing, commercial \& administrative, educational and general courses. Men on the other hand are over-represented in the technical and agricultural fields. In 1985, with an unchanged educational structure, $19 \%$ of the active labour force would have had to change their field of study in order to neutralize educational segregation by fields, whereas only $2 \%$ would have to shift to correct the educational segregation by level. The strong segregation in educational fields therefore indicates a rather strong pre-selection process (Groot, 1990).

Table 5.3. Educational segregation by educational levels in 1979 and 1985

1979

$\mathbf{s}$

S

1985

Level of education

$s$

$\mathrm{S}$

Lower Vocational Education, Lower General

Secondary Education

Intermediate Vocational Education, Higher

General Secondary Education

Higher Vocational Education

Academic Education

59

26

63

29

$55 \quad 22$

$52 \quad 23$

$38 \quad 16$

$37 \quad 18$

$33 \quad 32 \quad 10$

Exactly because the educational segregation by levels is much smaller than that by fields of study, we examined how this segregation by fields of study has developed between 1979 and 1985 . The

27. These are the four levels employed by the Standard Educational Classification (SOI) of the Central Bureau of Statistics: primary education, lower general and lower vocational education, secondary general and secondary vocational education, and tertiary education.

28. Five training fields are distinguished: general, educational, technical and agricultural, medical and nursing, and commercial and legal. 
field segregation indices have been determined for each educational level. From table 5.3 it can be seen that the segregation of men and women into education fields diminishes as the educational level rises. For workers with an L.V.E. or I.V.E. qualification, the division between typically men's and women's qualifications is therefore bigger than for those who have had an H.V.E. or academic education. The corrected segregation index $\mathrm{S}$ appears to have increased slightly at all educational levels between 1979 and 1985. This increase in the difference between the qualifications of working men and women is mainly because the share of women in the active labour force has grown from $29 \%$ in 1979 to $34 \%$ in 1985 . Indeed, the segregation index s has slightly decreased at all but the lowest levels (see also Van Mourik and Siegers, 1988). The difference shows the importance of presenting both indices.

In determining occupational segregation the indices were calculated on the basis of the number of working persons in each occupational class. Unlike Van Mourik and Siegers (1988), who only measured occupational segregation over the whole labour force, in this case the sex-specific occupational segregation is determined, with the changes in the period 1979-1985, for each function level (see table 5.4). ${ }^{29}$

Table 5.4. Occupational segregation by function levels in 1979 and 1985

\begin{tabular}{|c|c|c|c|c|c|}
\hline \multirow[t]{2}{*}{ Level of function } & \multirow{2}{*}{$\begin{array}{l}\text { number of occupational } \\
\text { classes }\end{array}$} & \multicolumn{2}{|c|}{1979} & \multicolumn{2}{|c|}{1985} \\
\hline & & $s$ & $S$ & $s$ & $S$ \\
\hline 1 & 31 & 49 & 19 & 61 & 28 \\
\hline 2 & 74 & 70 & 28 & 66 & 30 \\
\hline 3 & 42 & 66 & 31 & 62 & 31 \\
\hline 4 & 49 & 70 & 29 & 69 & 32 \\
\hline 5 & 58 & 70 & 26 & 64 & 26 \\
\hline 6 & 36 & 59 & 16 & 54 & 15 \\
\hline 7 & 24 & 35 & 12 & 30 & 12 \\
\hline Total & 314 & 66 & 27 & 64 & 28 \\
\hline
\end{tabular}

Occupational segregation appears to occur more in the intermediate occupational classes than in the higher or lower groups. It should however be taken into account that there is a slight positive correlation between the number of occupational classes and the value of the indices. Therefore no hard conclusions can be drawn from the differences between the values of the segregation indices at the various function levels.

29. The definition of the function levels was taken from Huijgen (1989). 
It is therefore better to analyze the differences between the function levels in relation to the changes in segregation between 1979 and 1985. With the exception of the lowest function level, the segregation index $s$ appears to have decreased at all function levels in the period under consideration, whereas the index $S$ has remained fairly constant between 1979 and 1985 . For the lowest function level, on the other hand, both indices increased strongly between 1979 and 1985 . This is probably because it is at the lowest function level that the number of women has most increased, and from which men have particularly withdrawn. The lowest function level therefore appears to be becoming more and more a 'women's segment' (see also Elfring and Kloosterman, 1989).

To end this subsection, it will be interesting to have a look at the extent to which the educational and occupational segregation are related to each other. This is mainly a question of how large the occupational segregation is for people with the same educational background. This occupational segregation, the so-called 'post-selection', is $14 \%$ according to Groot (1990). In principle the $14 \%$ post-selection effect came on top of a $20 \%$ pre-selection within the educational system. Two comments should be made however. In the first place, the pre-selection of $20 \%$ and the postselection of $14 \%$ do not add up to the total occupational segregation of $25-30 \%$, because the two components can in part compensate for each other. In the second place, within any one of the rather broad fields of education we have defined there may be several specific kinds of education in which either men or women are strongly over-represented. These may even be oriented for different occupational segments, as is the case for instance for the commercial and secretarial specialisations within the I.V.E. Commerce and Administration. This effect could mean that the importance of pre-selection is in reality even greater than we have shown above.

The conclusion regarding the educational and occupational segregation of men and women is that an important part of the total occupational segregation has its origin in a rather strong pre-selection in the course of education, but that occupational segregation becomes even stronger along the career path that follows. Moreover, both forms of segregation appear to be changing only gradually.

\subsection{Labour market characteristics of women's occupations}

This subsection will discuss a number of characteristics of typically 'female' occupational classes, that is, groups in which $60 \%$ or more of the practitioners in 1985 were women. ${ }^{30}$ The

30. As of the coming year, ROA wants to base its occupational data on a new classification of occupational classes resulting from a redefinition of occupational groups by the Central Bureau of Statistics. Occupations are clustered according to their training background. 
characteristics in question are given in table 5.5 .

In 1985 an average of $76 \%$ of the workers in these women's occupations are women, varying from $60 \%$ for the 'cooks, waiters and bartenders' to $96 \%$ for miscellaneous domestic, geriatric care, and hotel workers. In the total active labour force, $34 \%$ of workers are women. Thus one can conclude that there are twice as many women in these women's occupations as in an average occupational class.

Of the women working in 1985, 53\% appear to work in one of these eleven women's occupations; just six of these occupational classes account for $49 \%$ of the employment for women: medical, dental, veterinary, and pharmaceutical personnel and assistants, shop assistants and other sales personnel, maintenance and domestic personnel, secretaries and typists, cleaners and caretakers, and cooks, waiters and bartenders.

The function level of these occupational classes appears to be lower than average: only one of the eleven has a relatively high function level.

The 'relative prestige' of the women's occupations was also examined. This was done on the basis of a score for the social prestige of an occupational class, incorporating a correction for the function level (see also section 3). Only the medical, dental, veterinary, and pharmaceutical personnel have a high relative prestige. For seven of the eleven, the social prestige of the occupational class is lower than one would predict on the basis of the function level. This applies in particular to occupational classes with a lower function level.

In accordance with our expectations, the average proportion of part-timers ${ }^{31}$ in the women's occupations is high. For four of the eleven occupational classes the proportion of part-timers was very high. None of the women's occupations has a low percentage of part-timers.

Because sex and fields of training appear to be related to each other, the new occupational classes used by ROA will be more likely to be markedly female or markedly male. (See Dekker, De Grip and Van de Loo (1990)).

31. The proportion of working persons who, in the period 1979-1985, had a working week of less than 30 hours. 
Table 5.5. Labour market characteristics of women's occupations

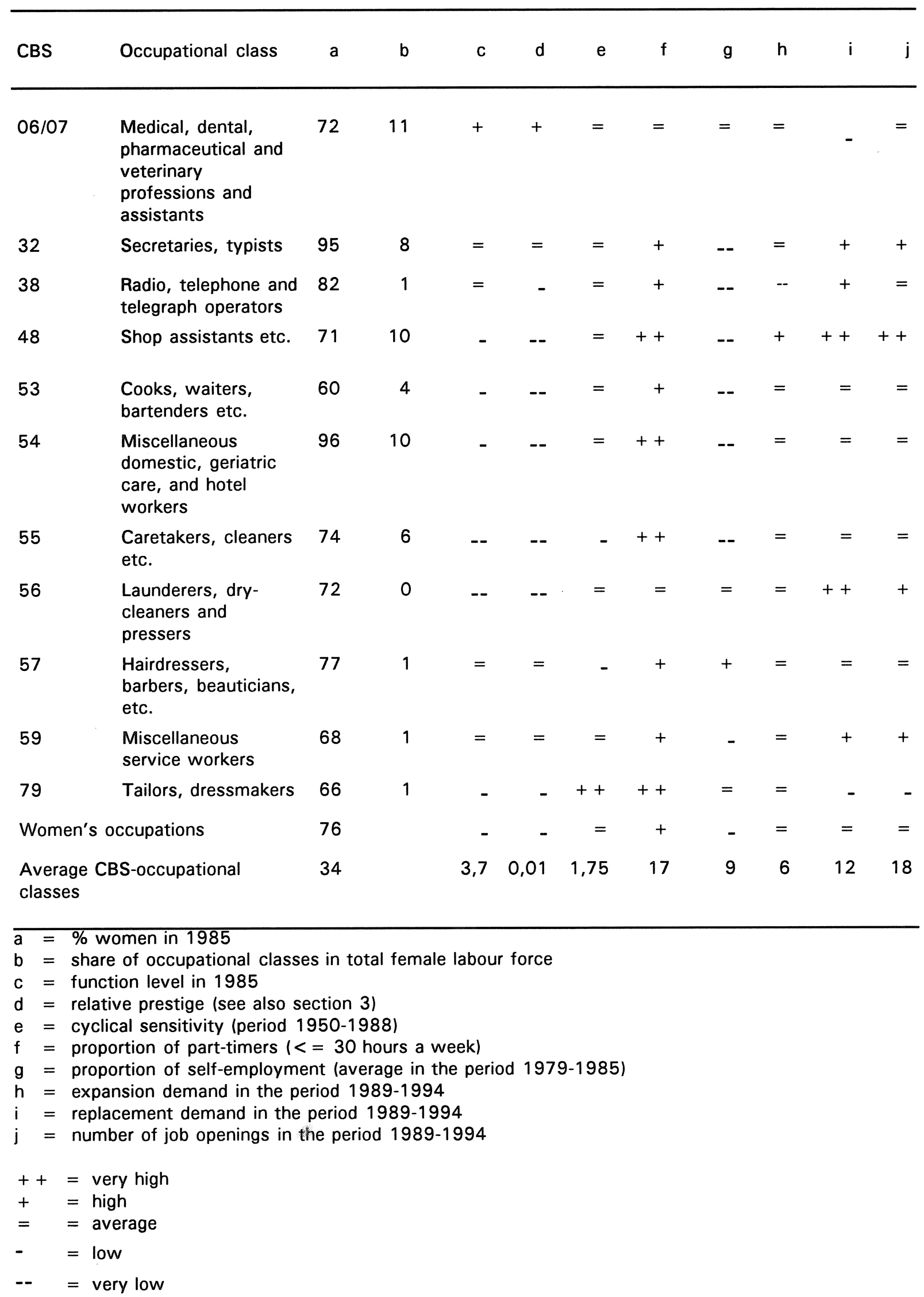


$-51-$

The average proportion of self-employment in the women's occupations could be called low. Among the hairdressers, barbers and beauticians there are relatively more smaller businessmen and business women. Within this occupational class however, relatively more women are in salaried employment than men (63\% versus $40 \%)$.

We also examined whether women's occupations are over-represented or under-represented in the economic sectors that are cyclically sensitive. With the exception of the very cyclically sensitive occupational class of tailors and dressmakers and upholsterers, the women's occupations appear to have an average and sometimes even relatively low cyclical sensitivity.

Thus far, we have discussed a number of the present characteristics of women's occupations. Needless to say, the labour market prospects for the near future are also of great importance for those working in these occupational classes. The sum of the expansion demand and the replacement demand, in the women's occupations in general, will result in an average to relatively high number of job openings in the period 1989-1994. The replacement demand often plays a more important part here than in other occupations, the often high or very high replacement demand reflecting the pattern of women's participation in the labour market.

In most cases, the expansion demand is the same as the average growth. The growth of employment will therefore be no better or worse in the women's occupations than in all occupational classes together. The only shrinking occupation among them was the radio, telephone and telegraph operators. On the other hand, the demand for shop assistants is expected to grow relatively strongly in the forecasting period. The occupational class of shop assistants and other sales personnel therefore belongs among the growing occupations.

Finally, appendix 10 provides a list of the main educational backgrounds for all women's occupations, differentiated by sex. From this it appears that there is a big difference between the qualifications of the two sexes. Men often appear to move into a 'women's occupation' with a completely different qualification than women.

\subsection{Labour market characteristics of women's types of education}

There were eight 'typically female' types of education, for which more than $60 \%$ of the workers with that background were women, in 1985. In that year, $37 \%$ of all working women held one of these eight qualifications. The percentage of those holding these types of qualification who were women varies from $60 \%$ for L.V.E. Commerce and Administration to $92 \%$ for the I.V.E. Community Care. The average figure, in 1985 , was $78 \%$, whereas only $34 \%$ of the active labour force are 
women. Table 5.6 gives a number of the labour market characteristics of the working people with one of these qualifications. Each is compared with the average score for the educational level in question.

At L.V.E. level the workers with a 'female' qualification appear to be more often unemployed and to have a higher than average occupational dispersion. Within this group there are large differences regarding function levels and the under-utilization of qualifications. Those with L.V.E. Community Care have, on average, a lower function level and are more likely to work below the level of their education than those with L.V.E. Commerce and Administration. Those with L.V.E. Commerce and Administration do not have very good prospects because employment in that field is expected to decrease strongly in the near future and this will not be compensated for by the high replacement demand and the very low inflow. For the L.V.E. Community Care, Hotel \& Catering Trades on the other hand, the very high replacement demand and very low inflow will amply compensate for the low expansion demand; good labour market prospects are therefore expected. This could mean that the differences in the labour market positions of those with L.V.E. Community Care, Hotel \& Catering Trades and L.V.E. Commerce and Administration will decrease in the future.

Workers with one of the 'female' qualifications at I.V.E. level appear on average to have a higher function level and to work less often below their level than is the case for I.V.E. qualifications in general. The rather good labour market prospect for school leavers with a 'female' qualification at I.V.E. level are due especially to the high replacement demand. The education in 'Community Care' does not entirely fit this image of I.V.E. education. Workers with this educational background have a greater occupational dispersion, a lower function level and the majority of them work below the level of their education. Because of a relatively high flow of school leavers onto the labour market they have only limited labour market prospects, despite the very high number of job openings.

At the H.V.E. level the occupational dispersion of workers with a 'female' educational background appears to be considerably less than average. Although the function level for those with women's education is lower than the average for H.V.E., they are no more likely to work below the level of their education. For the H.V.E. Nursing \& Physiotherapy, low replacement demand in the period 1989-1994 and a high inflow of school leavers is expected. In combination with an expansion demand which is no more than average, this points to bad labour market prospects. For the higher medical laboratory education on the other hand, the good labour market prospects are due in the first place to the low inflow of school leavers. 
Table 5.6. Labour market characteristics of women's types of education

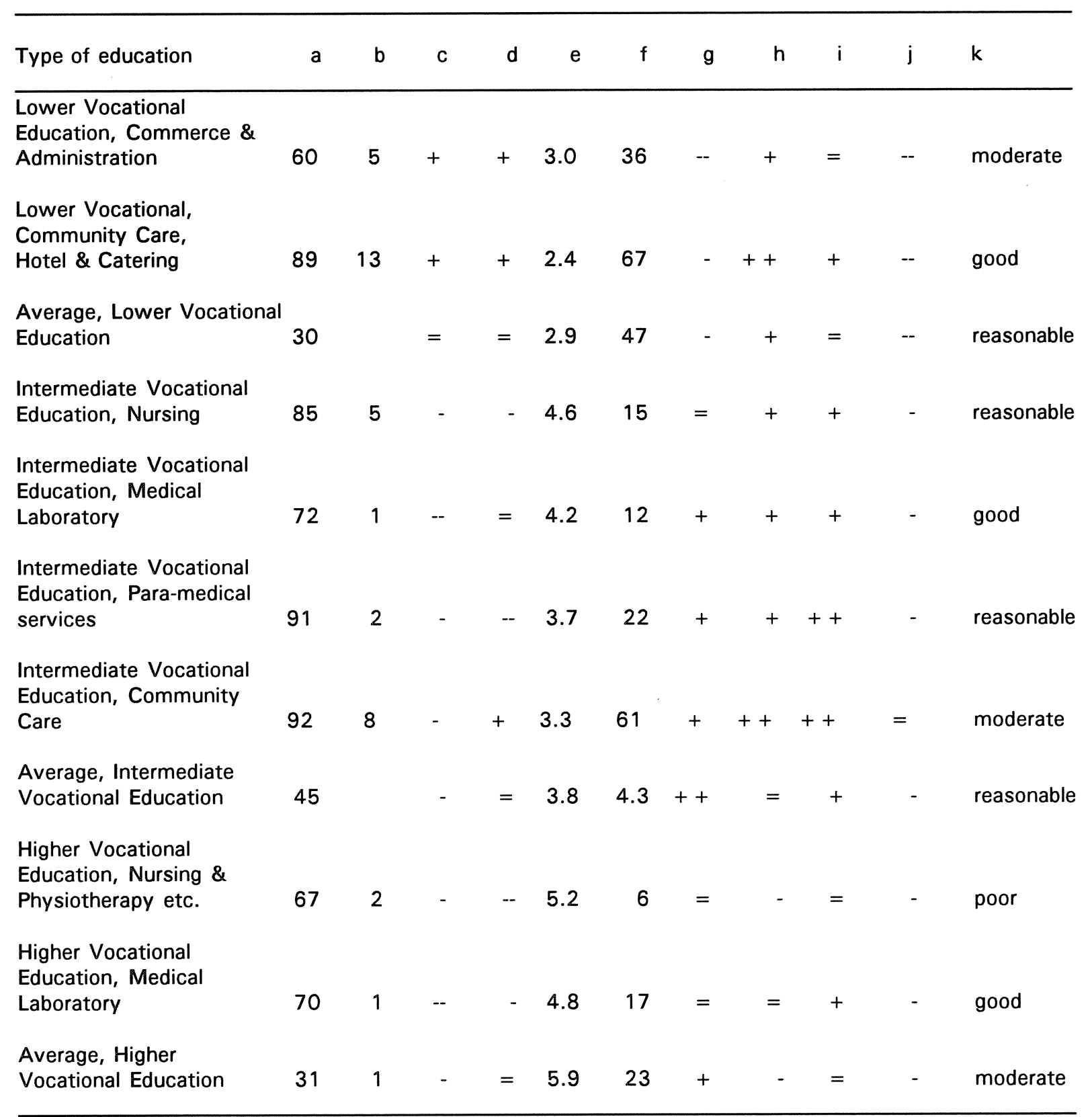

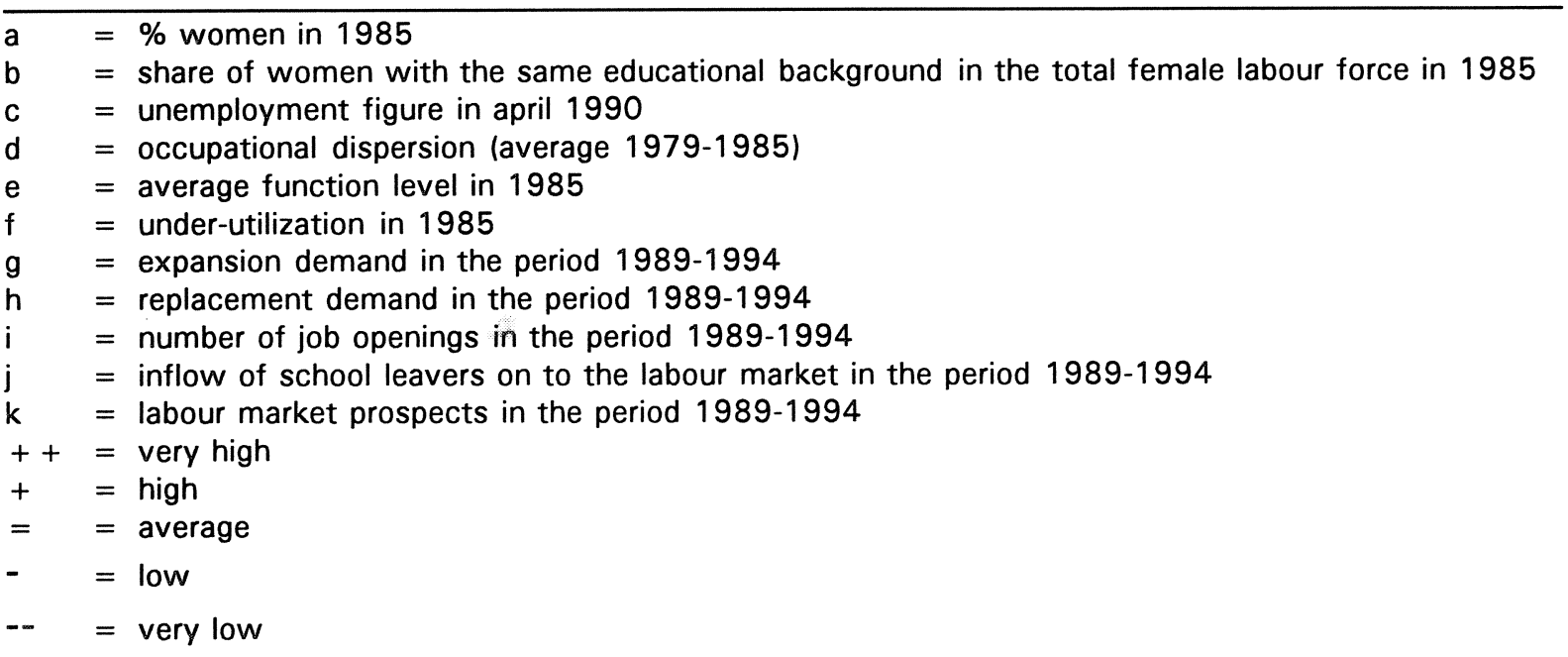


$-54-$

Just as for the women's occupations, the data for those working with a 'female' educational background, men and women, has been examined to see which occupational class they were working in 1985 (see appendix 11). From this we can see that, even if they have had the same educational background, men and women end up in different occupations. As was already observed in subsection 5.3 as regards educational and occupational segregation, the occupational differences between men and women cannot therefore be entirely attributed to 'pre-selection' in education. 


\section{REFERENCES}

Beekman, Th.B.J., R.J.P. Dekker, A. de Grip, J.A.M. Heijke (1989), An explanation of the educational structure of occupations, ROA-W-1989/3E, Maastricht.

Bruyn-Hundt, M. (1988), Vrouwen op de arbeidsmarkt, Nederlandse situatie in de jaren tachtig en negentig, Scala-reeks, Het Spectrum, Utrecht.

Centraal Bureau voor de Statistiek (1989), Statistiek van het Ondernemingenbestand, Voorburg/Heerlen.

Commissie OAP (1989), Verslag van de werkgroep 'vergelijking en afstemming prognoses '89', Den Haag.

Dam, J.W. van, A. de Grip (1990), Technology indicators: Population, Labour and Schooling, ROAR-1990/5E, Maastricht.

Dekker, R.J.P., A. de Grip, J.A.M. Heijke (1990), An explanation of the occupational structure of sectors of industry, in: Labour, vol. 4, nr. 3.

Dekker, R.J.P., A. de Grip, P.J.E. van de Loo (1990), ROA-Beroepenclassificatie 1990, ROA-W1990/9, Maastricht.

Elfring, T., R.C. Kloosterman (1989), De Nederlandse 'Jobmachine'; de snelle expansie van laagbetaald werk in de dienstensector 1979-1986, Paper Ecozoek, Economisch Geografisch Instituut (EGI), Amsterdam.

Grip, A. de (1987), Winnaars en verliezers op de arbeidsmarkt 1981-1985, in: Tijdschrift voor Arbeidsvraagstukken, volume 3, nr. 4, pp. 61-69.

Grip, A. de, J.A.M. Heijke, R.J.P. Dekker (1989), De arbeidsmarkt naar opleiding en beroep in 1992, ROA-R-1989/8, Maastricht.

Groot, L.F.M. (1990), De onderwijs- en beroepssegregatie tussen mannen en vrouwen in de jaren tachtig, in: Tijdschrift voor Arbeidsvraagstukken (TvA), 1990/4, pp. 4-12.

Huijgen, F. (1989), De kwalitatieve structuur van de werkgelegenheid in Nederland, deel III, bevolking in loondienst en functiestructuur in 1977 en 1985, OSA-voorstudie nr. V 33, Organisatie voor Strategisch Arbeidsmarktonderzoek (OSA), Den Haag.

Kuhry, B., R.M. van Opstal (1987), De arbeidsmarkt naar opleidingscategorie 1975-2000, CPB-W1987/17, Centraal Planbureau (CPB), Den Haag.

Loo, P.J.E. van de, R.K.W. van der Velden (1991), Sexe, onderwijs en arbeidsmarkt, Researchcentrum voor Onderwijs en Arbeidsmarkt (ROA), Maastricht (to appear shortly).

Ministerie van Sociale Zaken en Werkgelegenheid (1990), Rapportage Arbeidsmarkt 1990, Ministerie van Sociale Zaken en Werkgelegenheid, Den Haag.

Mourik, A. van, J. Siegers (1988), Ontwikkelingen in de beroepssegregatie tussen mannen en vrouwen, 1971-1985, in: Economisch Statistische Berichten (ESB), 1988, pp. 732-737.

Peeters, H.M.M. (1990), An explanation of the occupational and educational structure of employment by means of multinomial logit, ROA-W-1990/4E, Maastricht.

Siegers, J. (1979), Beroepssegregatie tussen mannen en vrouwen in Nederland, in: Economisch 
Statistische Berichten (ESB), 1979, pp. 208-213.

Sixma, H., W.C. Ultee (1983), Een beroepsprestigeschaal voor de jaren tachtig, in: Mens en Maatschappij, 4, pp. 360-382.

Teulings, C.N., H.D. Webbink (1990), Verschuivingen in werkgelegenheidsstructuren, in: Economische Statistische Berichten, vol. 75, nr. 3759, pp. 469-472.

Wieling, M.H., A. de Grip en E.J.T.A. Willems (1990), Een systematische kwalitatieve qualification van arbeidsmarktinformatie, ROA-W-1990/8, Maastricht.

Willems, E.J.T.A., A. de Grip (1990), Vervangingsvraagprognoses naar beroep en opleiding, ROAW-1990/7, Maastricht. 
Appendix 1: Expansion demand 1989-1994 per occupational class, absolute and as a percentage of the total labour force in 1989

\begin{tabular}{|c|c|c|c|c|}
\hline CBS & Occupational class & number & $\%$ & qualification \\
\hline 01 & Physical scientist and related technicians & 250 & 1 & average \\
\hline $02 / 03$ & Architects, engineers and related technicians & 21200 & 11 & relatively high \\
\hline 04 & Aircraft and ships' officers & 1400 & 10 & relatively high \\
\hline 05 & Life scientists and technicians & 1300 & 4 & average \\
\hline 06/07 & $\begin{array}{l}\text { Medical, dental, pharmaceutical and veterinary } \\
\text { professions and assistants }\end{array}$ & 20200 & 7 & average \\
\hline 08 & Programmers, statisticians, and assistants, etc. & 45400 & 57 & relatively very high \\
\hline 09 & Economists & 500 & 3 & average \\
\hline 11 & Accountants & 650 & 5 & average \\
\hline 12 & Legal professionals and assistants & 550 & 3 & average \\
\hline 13 & Teachers & 3900 & 1 & average \\
\hline 14 & Ministers of religion etc. & 400 & 5 & average \\
\hline 15 & Authors, journalists etc. & 7400 & 26 & relatively very high \\
\hline 16 & Creative artists and industrial and interior designers & 1300 & 4 & average \\
\hline 17 & Performing artists & 600 & 4 & average \\
\hline 18 & Sports professionals etc. & 400 & 4 & average \\
\hline 19 & Miscellaneous professions & 3400 & 3 & average \\
\hline 20 & Senior Government appointees & 50 & 1 & average \\
\hline 21 & Company directors and senior executives & 42300 & 20 & relatively very high \\
\hline 30 & Departmental managers, administration & 350 & 2 & average \\
\hline 31 & Senior civil servants & 250 & 1 & average \\
\hline 32 & Secretaries, typists etc. & 5100 & 3 & average \\
\hline 33 & Bookkeepers, cashiers etc. & 12600 & 4 & average \\
\hline 34 & Computer operators etc. & 450 & 3 & average \\
\hline 35 & Transport supervisors & -100 & -0 & average \\
\hline 36 & Conductors, transport services & -150 & -5 & relatively low \\
\hline 37 & Postal workers and mail clerks & 22000 & 35 & relatively very high \\
\hline 38 & Radio, telephone and telegraph operators & -3300 & -23 & relatively very low \\
\hline 39 & Miscellaneous administrative personnel & 10700 & 3 & average \\
\hline 40 & Managers, wholesale & 4600 & 12 & relatively high \\
\hline 41 & Managers, retail & 2100 & 12 & relatively high \\
\hline 42 & Working proprietors, wholesale & 3500 & 12 & relatively high \\
\hline 43 & Working proprietors, retail & 12300 & 12 & relatively high \\
\hline 45 & Departmental managers, purchasing and sales & -7100 & -18 & relatively very low \\
\hline 46 & Sales representatives & 4100 & 7 & average \\
\hline 47 & Insurance agents, real estate agents etc. & 1300 & 4 & average \\
\hline 48 & Shop assistants etc. & 29700 & 10 & relatively high \\
\hline 50 & Managers, hotel and catering industry & 550 & 5 & average \\
\hline 51 & Working proprietors, hotel and catering industry & 1600 & 5 & average \\
\hline 52 & Supervisors, catering cleaning and maintenance & 550 & 5 & average \\
\hline 53 & Cooks, waiters, bartenders etc. & 5000 & 4 & average \\
\hline \multirow[t]{2}{*}{54} & Miscellaneous domestic, geriatric care, and & & & \\
\hline & hotel workers & 7900 & 5 & average \\
\hline 55 & Caretakers, cleaners, etc. & 5200 & 4 & average \\
\hline 56 & Launderers, dry-cleaners and pressers & 500 & 5 & average \\
\hline 57 & Hairdressers, barbers, beauticians, etc. & 1600 & 5 & average \\
\hline 58 & Fire, police, and security officers & 850 & 1 & average \\
\hline 59 & Miscellaneous service workers & 1800 & 6 & average \\
\hline 60 & Farm managers and supervisors & -150 & -2 & relatively low \\
\hline 61 & Farmers & 3500 & -3 & relatively low \\
\hline 62 & Agricultural workers & -2300 & -2 & relatively low \\
\hline 63 & Forestry workers & -50 & -1 & relatively low \\
\hline 64 & Fishermen, hunters etc. & -50 & -2 & relatively low \\
\hline 70 & Production supervisors and general foremen & -450 & -1 & relatively low \\
\hline 72 & Furnace, casting, and galvanising workers etc. & -150 & -1 & relatively low \\
\hline 73 & Timber, pulp and paper workers & -200 & -3 & relatively low \\
\hline 74 & Chemical process workers etc. & 50 & 1 & average \\
\hline
\end{tabular}




\begin{tabular}{|c|c|c|c|c|}
\hline CBS & Occupational class & number & $\%$ & qualification \\
\hline 75 & Spinners, weavers, knitters, dyers, etc. & -350 & -3 & relatively low \\
\hline 77 & Food and beverage processors, abattoir workers & 3300 & -5 & relatively low \\
\hline 78 & Tobacco and tobacco product workers & -250 & -11 & relatively very low \\
\hline 79 & Tailors, dressmakers etc. & 400 & 1 & average \\
\hline 80 & Shoemakers and leather goods workers & -100 & -1 & relatively low \\
\hline \multirow[t]{2}{*}{$\begin{array}{l}82 \\
83\end{array}$} & $\begin{array}{l}\text { Cabinetmakers, woodworkers, stonemasons etc. } \\
\text { Blacksmiths, toolmakers, and miscellaneous }\end{array}$ & 150 & 1 & average \\
\hline & metalworkers & -3900 & -14 & relatively very low \\
\hline 84 & Lathe operators, mechanics, etc. & 3500 & 2 & average \\
\hline 85 & Electrical and electronics workers & -1100 & -1 & relatively low \\
\hline 87 & Plumbers, welders, sheet metal workers, etc. & 700 & 1 & average \\
\hline 89 & Glass and ceramics workers etc. & 0 & -0 & average \\
\hline 90 & Procesworkers, rubber and plastic products & 150 & 1 & average \\
\hline 91 & Process workers, paper and card products & -200 & -4 & relatively low \\
\hline 92 & Printers and related functions & -2100 & -5 & relatively low \\
\hline 93 & Painters & 500 & 1 & average \\
\hline 94 & Miscellaneous craftsmen and production workers & 1000 & 7 & average \\
\hline 95 & Building trades and construction workers & -3200 & -2 & relatively low \\
\hline 96 & Machine operators & -100 & -2 & relatively low \\
\hline \multirow[t]{2}{*}{97} & Freight handlers, packers \& construction & & & \\
\hline & machine operators & 46600 & 25 & relatively very high \\
\hline 98 & Drivers, sailors, engine drivers & -1400 & -1 & relatively low \\
\hline 99 & Miscellaneous labourers & 500 & 1 & average \\
\hline 69 & Military professionals & 500 & 1 & average \\
\hline
\end{tabular}


Appendix 2: Replacement demand 1989-1994 per occupational class, absolute and as percentage of the total labour force in 1989

\begin{tabular}{|c|c|c|c|c|}
\hline CBS & Occupational class & number & $\%$ & qualification \\
\hline 01 & Physical scientists and related technicians & 5500 & 16 & relatively high \\
\hline $02 / 03$ & Architects, engineers and related technicians & 16200 & 8 & relatively low \\
\hline 04 & Aircraft and ships' officers & 1900 & 14 & average \\
\hline 05 & Life scientists and technicians & 2800 & 9 & relatively low \\
\hline \multirow[t]{2}{*}{ 06/07 } & Medical, dental, pharmaceutical and & & & \\
\hline & veterinary professions and assistants & 22100 & 8 & relatively low \\
\hline 08 & Programmers, statisticians, and assistants, etc. & 1600 & 2 & relatively very low \\
\hline 09 & Economists & 1600 & 10 & average \\
\hline 11 & Accountants & 1400 & 10 & average \\
\hline 12 & Legal professionals and assistants & 1600 & 8 & relatively low \\
\hline 13 & Teachers & 25300 & 8 & relatively low \\
\hline 14 & Minister of religion etc. & 1700 & 19 & relatively high \\
\hline 15 & Authors, journalists etc. & 1100 & 4 & relatively very low \\
\hline 16 & Creative artists and industrial and interior designers & s 3700 & 12 & average \\
\hline 17 & Performing artists & 1300 & 9 & relatively low \\
\hline 18 & Sports professionals etc. & 1300 & 14 & average \\
\hline 19 & Miscellaneous professions & 8300 & 8 & relatively low \\
\hline 20 & Senior Government appointees & 550 & 11 & average \\
\hline 21 & Company directors and senior executives & 18700 & 9 & relatively low \\
\hline 30 & Departmental managers, administration & 1400 & 8 & relatively low \\
\hline 31 & Senior civil servants & 400 & 2 & relatively very low \\
\hline 32 & Secretaries, typists, etc. & 27300 & 18 & relatively high \\
\hline 33 & Bookkeepers, cashiers etc. & 38300 & 13 & average \\
\hline 34 & Computer operators etc. & 1700 & 14 & average \\
\hline 35 & Transport supervisors & 3300 & 12 & average \\
\hline 36 & Conductors, transport services & 200 & 7 & relatively low \\
\hline 37 & Postal workers and mail clerks & 4000 & 6 & relatively low \\
\hline 38 & Radio, telephone and telegraph operators & 2900 & 20 & relatively very high \\
\hline 39 & Miscellaneous administrative personnel & 48100 & 12 & average \\
\hline 40 & Managers, wholesale & 2800 & 7 & relatively low \\
\hline 41 & Managers, retail & 1500 & 9 & relatively low \\
\hline 42 & Working proprietors, wholesale & 2300 & 8 & relatively low \\
\hline 43 & Working proprietors, retail & 6900 & 7 & relatively low \\
\hline 45 & Departmental managers, purchasing and sales & 6900 & 17 & relatively high \\
\hline 46 & Sales representatives & 5500 & 10 & average \\
\hline 47 & Insurance agents, real estate agents etc. & 4700 & 14 & average \\
\hline 48 & Shop assistants etc. & 55200 & 19 & relatively high \\
\hline 50 & Managers, hotel and catering industry & 1300 & 11 & average \\
\hline 51 & Working proprietors, hotel and catering industry & 5100 & 15 & average \\
\hline 52 & Supervisors, catering cleaning and maintenance & 1700 & 16 & relatively high \\
\hline 53 & Cooks, waiters, bartenders etc. & 15900 & 14 & average \\
\hline \multirow[t]{2}{*}{54} & Miscellaneous domestic, geriatric care, and & & & \\
\hline & hotel workers & 25300 & 15 & average \\
\hline 55 & Caretakers, cleaners, etc. & 14900 & 10 & average \\
\hline 56 & Launderers, dry-cleaners and pressers & 2000 & 18 & relatively high \\
\hline 57 & Hairdressers, barbers, beauticians, etc. & 4500 & 14 & average \\
\hline 58 & Fire, police, and security officers & 4500 & 7 & relatively low \\
\hline 59 & Miscellaneous service workers & 4600 & 14 & average \\
\hline 60 & Farm managers and supervisors & 1600 & 21 & relatively very high \\
\hline 61 & Farmers & 17300 & 13 & average \\
\hline 62 & Agricultural workers & 24300 & 18 & relatively high \\
\hline 63 & Forestry workers & 250 & 6 & relatively low \\
\hline 64 & Fishermen, hunters etc. & 800 & 22 & relatively very high \\
\hline 70 & Production supervisors and general foremen & 13600 & 17 & relatively high \\
\hline 72 & Furnace, casting, and galvanising workers etc. & 2000 & 20 & relatively very high \\
\hline 73 & Timber, pulp and paper workers & 950 & 12 & average \\
\hline 74 & Chemical process workers etc. & 2900 & 11 & average \\
\hline
\end{tabular}




\begin{tabular}{|c|c|c|c|c|}
\hline CBS & Occupational class & number & $\%$ & qualification \\
\hline 75 & Spinners, weavers, knitters, dyers, etc. & 1000 & 10 & average \\
\hline 77 & Food and beverage processors, abattoir workers & 9700 & 16 & relatively high \\
\hline 78 & Tobacco and tobacco product workers & 100 & 4 & relatively very low \\
\hline 79 & Tailors, dressmakers etc. & 2900 & 9 & relatively low \\
\hline 80 & Shoemakers and leather goods workers & 1100 & 14 & average \\
\hline \multirow[t]{2}{*}{83} & $\begin{array}{l}\text { Cabinetmakers, woodworkers, stonemasons etc. } \\
\text { Blacksmiths, toolmakers, and miscellaneous }\end{array}$ & 800 & 4 & relatively very low \\
\hline & metalworkers & 4100 & 14 & average \\
\hline 84 & Lathe operators, mechanics, etc. & 23500 & 14 & average \\
\hline 85 & Electrical and electronics workers & 13100 & 12 & average \\
\hline 87 & Plumbers, welders, sheet metal workers, etc. & 10900 & 12 & average \\
\hline 89 & Glass and ceramics workers etc. & 900 & 10 & average \\
\hline 90 & Procesworkers, rubber and plastic products & 2100 & 16 & relatively high \\
\hline 91 & Process workers, paper and card products & 600 & 11 & average \\
\hline 92 & Printers and related functions & 6100 & 14 & average \\
\hline 93 & Painters & 2400 & 7 & relatively low \\
\hline 94 & Miscellaneous craftsmen and production workers & 800 & 6 & relatively low \\
\hline 95 & Building trades and construction workers & 14200 & 8 & relatively low \\
\hline 96 & Machine operators & 800 & 13 & average \\
\hline \multirow[t]{2}{*}{97} & Freight handlers, packers \& construction & & & \\
\hline & machine operators & 22500 & 12 & average \\
\hline 98 & Drivers, sailors, engine drivers & 20800 & 13 & average \\
\hline 99 & Miscellaneous labourers & 2200 & 5 & relatively very low \\
\hline 69 & Military professionals & 9300 & 22 & relatively very high \\
\hline
\end{tabular}


Appendix 3: Number of job openings per type of education in the period 1989-1994, absolute and as percentage of the total labour force in 1989, divided in expansion and replacement demand

number $\quad \% \quad$ qualification

$\%$ replacement \% expansion

Primary Education

Primary Education

Lower General Secondary Education

Lower Vocational Education, Agriculture

Lower Vocational Education, Technical

Lower Vocational Education, Transport \&

Harbour

Lower Vocational Education, Commerce

\& Administration

Lower Vocational Education, Community

Care, Hotel \& Catering

Lower Vocational Education, Security

Higher General Secondary Education

Intermediate Vocational Education,

Agriculture

Intermediate Vocational Education,

Engineering and Laboratory

Intermediate Vocational Education,

Transport, Harbour \&

Telecommunications

Intermediate Vocational Education, Nursing

Intermediate Vocational Education, Medical

Laboratory

Intermediate Vocational Education, Para-

medical services

Intermediate Vocational Education,

Commerce \& Administration

Intermediate Vocational Education,

Administrative, Legal \& Fiscal

Intermediate Vocational Education, Social

\& Cultural

Intermediate Vocational Education,

Community Care

Intermediate Vocational Education, Hotel,

Catering \& Hairdressing

Intermediate Vocational Education, Police,

Fire \& Defense Forces

Higher Vocational Education, Teacher

Education

Higher Vocational Education, Interpreter

\& Translator

Higher Vocational Education, Theology

Higher Vocational Education, Agriculture

Higher Vocational Education, Non-medical

Laboratory

Higher Vocational Education, Engineering

Higher Vocational Education, Air, Sea and

Land Transport

Higher Vocational Education, Nursing \&

Physiotherapy etc.

Higher Vocational Education, Medical

Laboratory

\begin{tabular}{|c|c|c|c|c|}
\hline 39200 & 6 & relatively low & 100 & 0 \\
\hline 67000 & 15 & average & 64 & 36 \\
\hline 8100 & 8 & relatively low & 100 & 0 \\
\hline 57100 & 12 & average & 100 & 0 \\
\hline 6200 & 27 & relatively very high & 32 & 68 \\
\hline 11300 & 11 & relatively low & 100 & 0 \\
\hline 41100 & 18 & average & 85 & 15 \\
\hline 300 & 3 & relatively very low & 100 & 0 \\
\hline 34500 & 15 & average & 45 & 55 \\
\hline 18500 & 17 & average & 46 & 54 \\
\hline 103700 & 18 & average & 43 & 57 \\
\hline 8100 & 18 & average & 40 & 60 \\
\hline 20700 & 21 & relatively high & 58 & 42 \\
\hline 4500 & 21 & relatively high & 52 & 48 \\
\hline 8700 & 24 & relatively high & 60 & 40 \\
\hline 227800 & 31 & relatively very high & 15 & 85 \\
\hline 3800 & 9 & relatively low & 95 & 5 \\
\hline 3300 & 12 & average & 63 & 37 \\
\hline 41600 & 29 & relatively very high & 61 & 39 \\
\hline 6700 & 19 & average & 51 & 49 \\
\hline 9000 & 16 & average & 51 & 49 \\
\hline 25800 & 12 & average & 68 & 32 \\
\hline 350 & 5 & relatively low & 100 & 0 \\
\hline 700 & 19 & average & 62 & 38 \\
\hline 1300 & 11 & relatively low & 62 & 38 \\
\hline 3200 & 15 & average & 35 & 65 \\
\hline 20500 & 18 & average & 36 & 64 \\
\hline 2700 & 11 & relatively low & 81 & 19 \\
\hline 5600 & 12 & average & 36 & 64 \\
\hline 2700 & 18 & average & 53 & 47 \\
\hline
\end{tabular}


Higher Vocational Education, Commerce

\& Administration
Higher Vocational Education, Business

Administration Technology
Higher Vocational Education, Administrative,

Legal \& Fiscal

Higher Vocational Education, Social

\& Cultural

Higher Vocational Education, Hotel \&

Catering Industry

Higher Vocational Education, Fine arts

Higher Vocational Education, Police, Fire

\& Defense Forces

Academic Education, Teacher training

Academic Education, Arts

$\begin{array}{rrrrr}34000 & 24 & \text { relatively high } & 17 & 83 \\ 1500 & 42 & \text { relatively very high } & 12 & 88 \\ 1700 & 12 & \text { average } & 56 & 44 \\ 9800 & 14 & \text { average } & 42 & 58 \\ 750 & 19 & \text { average } & 43 & 57 \\ 1800 & 7 & \text { relatively low } & 100 & 0\end{array}$

\section{3}

88

Academic Education, Theology

Academic Education, Agriculture

Academic Education, Mathematics \&

Natural Sciences

Academic Education, Engineering

$\begin{array}{lllll}850 & 11 & \text { relatively low } & 66 & 34\end{array}$

$\begin{array}{llll}1500 & 7 & \text { relatively low } & 60\end{array}$

$\begin{array}{llll}1700 & 8 & \text { relatively low } & 65\end{array}$

$\begin{array}{llll}1300 & 18 & \text { average } & 81\end{array}$

$\begin{array}{llll}650 & 11 & \text { relatively low } & 53\end{array}$

$\begin{array}{llll}4000 & 14 & \text { average } & 49\end{array}$

$\begin{array}{llll}10200 & 21 & \text { relatively high } & 28\end{array}$

Academic Education, Veterinary \& Medical

Sciences \& Dentistry

Academic Education Pharmacy

$\begin{array}{llll}4400 & 9 & \text { relatively low } & 40\end{array}$

Academic Education, Economics \&

Business Administration

$500 \quad 13$ average 34

$34 \quad 66$

Academic Education, Econometrics \&

Business Administration Technology

Academic Education, Law \& Public

Administration

$\begin{array}{lllll}10300 & 35 & \text { relatively very high } & 17 & 83\end{array}$

$\begin{array}{llll}3100 & 74 & \text { relatively very high } & 5\end{array}$

Academic Education, Social Sciences

Academic Education, Fine arts

relatively low

relatively low 
Appendix 4: Outflow of school leavers per educational type in the period 1989-1994, absolute and as percentage of the total labour force in 1989

Type of education

number $\quad \% \quad$ qualification

Primary Education

Lower General Secondary Education

Lower Vocational Education, Agriculture

Lower Vocational Education, Technical

Lower Vocational Education, Transport \& Harbour

Lower Vocational Education, Commerce

\& Administration

Lower Vocational Education, Community

Care, Hotel \& Catering

Lower Vocational Education, Security

Higher General Secondary Education

Intermediate Vocational Education, Agriculture

Intermediate Vocational Education,

Engineering and Laboratory

Intermediate Vocational Education, Transport,

Harbour \& Telecommunications

Intermediate Vocational Education, Nursing

Intermediate Vocational Education, Medical

Laboratory

Intermediate Vocational Education, Para-

medical services

Intermediate Vocational Education, Commerce

\& Administration

Intermediate Vocational Education, Administrative,

Legal \& Fiscal

Intermediate Vocational Education, Social

\& Cultural

Intermediate Vocational Education, Community

Care

Intermediate Vocational Education, Hotel,

Catering \& Hairdressing

Intermediate Vocational Education, Police,

Fire \& Defense Forces

Higher Vocational Education, Teacher

Education

Higher Vocational Education, Interpreter

\& Translator

Higher Vocational Education, Theology

Higher Vocational Education, Agriculture

Higher Vocational Education, Non-medical

Laboratory

Higher Vocational Education, Engineering

Higher Vocational Education, Air, Sea and

Land Transport

Higher Vocational Education, Nursing \&

Physiotherapy etc.

Higher Vocational Education, Medical

Laboratory

Higher Vocational Education, Commerce

\& Administration

Higher Vocational Education, Business

Administration Technology

Higher Vocational Education, Administrative,

Legal \& Fiscal

Higher Vocational Education, Social

\& Cultural
142500

37200

10300

54200

1000

2900

20700

3000

126400

36700

157500

6300

33100

3600

12400

132800

4300

20900

70300

9200

6500

37900

650

650

9200

4600

35800

3100

28000

2500

33300

4100

118

3200

22

26000

38 relatively low average relatively high average

average

relatively low average

average

average

average

relatively low

relatively high

relatively high

average

relatively low

average

relatively low

$$
\text { average }
$$

relatively very high

average

average

relatively low

relatively high

average

average

relatively very high

average

average 
Higher Vocational Education, Hotel \&

Catering Industry

Higher Vocational Education, Fine arts

2100

9500

55

Higher Vocational Education, Police, Fire

\& Defense Forces

Academic Education, Teacher training

Academic Education, Arts

Academic Education, Theology

Academic Education, Agriculture

Academic Education, Mathematics \&

Natural Sciences

Academic Education, Engineering

Academic Education, Veterinary \& Medical

Sciences \& Dentistry

Academic Education Pharmacy

Academic Education, Economics \& Business

Administration

Academic Education, Econometrics \& Business

Administration Technology

Academic Education, Law \& Public Administration

Academic Education, Social Sciences

Academic Education, Fine arts

1300

2800

18000

750

4200

8100

17000

9400

1600

19700

3700

23500

22800

3100

1233800
55

38

15

14

83

10

70

29

35

20

41

68

89

73

55

164

23

average relatively high

average

average

relatively low

relatively very high

relatively low

relatively high

average

average

average

relatively high

relatively high

relatively very high

relatively high

relatively high

relatively very high 
Primary Education

Lower General Secondary Education

Lower Vocational Education, Agriculture

Lower Vocational Education, Technical

Lower Vocational Education, Transport \& Harbour

Lower Vocational Education, Commerce

\& Administration

Lower Vocational Education, Community

Care, Hotel \& Catering

Lower Vocational Education, Security

Higher General Secondary Education

Intermediate Vocational Education, Agriculture

Intermediate Vocational Education,

Engineering and Laboratory

Intermediate Vocational Education, Transport,

Harbour \& Telecommunications

Intermediate Vocational Education, Nursing

Intermediate Vocational Education, Medical

Laboratory

Intermediate Vocational Education, Para-

medical services

Intermediate Vocational Education, Commerce

\& Administration

Intermediate Vocational Education, Administrative,

Legal \& Fiscal

Intermediate Vocational Education, Social

\& Cultural

Intermediate Vocational Education, Community

Care

Intermediate Vocational Education, Hotel,

Catering \& Hairdressing

Intermediate Vocational Education, Police,

Fire \& Defense Forces

Higher Vocational Education, Teacher

Education

Higher Vocational Education, Interpreter

\& Translator

Higher Vocational Education, Agriculture

Higher Vocational Education, Non-medical

Laboratory

Higher Vocational Education, Engineering

Higher Vocational Education, Air, Sea and

Land Transport

Higher Vocational Education, Nursing \&

Physiotherapy etc.

Higher Vocational Education, Medical

Laboratory

Higher Vocational Education, Commerce

\& Administration

Higher Vocational Education, Business

Administration Technology

Higher Vocational Education, Administrative,

Legal \& Fiscal

Higher Vocational Education, Social

\& Cultural
1.52

1.01

1.07

1.11

0.84

1.26

0.99

1.43

1.44

1.15

1.09

0.98

1.14

1.01

1.10

0.91

1.02

1.63

1.19

1.08

1.01

1.08

1.25

1.00

1.64

poor labour market prospects good labour market prospects reasonable labour market prospects reasonable labour market prospects good labour market prospects

moderate labour market prospects

good labour market prospects poor labour market prospects poor labour market prospects reasonable labour market prospects

reasonable labour market prospects

good labour market prospects reasonable labour market prospects

good labour market prospects

reasonable labour market prospects

good labour market prospects

good labour market prospects

poor labour market prospects

moderate labour market prospects

reasonable labour market prospects

good labour market prospects

reasonable labour market prospects

moderate labour market prospects good labour market prospects poor labour market prospects

1.07

1.13

reasonable labour market prospects reasonable labour market prospects

good labour market prospects

1.47

poor labour market prospects

1.00

good labour market prospects

1.00

good labour market prospects

1.55

poor labour market prospects

1.12

reasonable labour market prospects

1.27 moderate labour market prospects 
Higher Vocational Education, Hotel \&

Catering Industry

Higher Vocational Education, Fine arts

1.49

Higher Vocational Education, Police, Fire

1.09

\& Defense Forces

1.08

Academic Education, Teacher training

1.80

Academic Education, Arts

0.95

Academic Education, Theology

1.64

Academic Education, Agriculture

1.18

Natural Sciences

1.13

Academic Education, Engineering

1.13

Sciences \& Dentistry

1.27

Academic Education Pharmacy

Administration

1.62

1.48

2.62

Administration Technology

Academic Education, Law \& Public Administration

Academic Education, Social Sciences moderate labour market prospects poor labour market prospects

reasonable labour market prospects reasonable labour market prospects poor labour market prospects good labour market prospects poor labour market prospects

moderate labour market prospects reasonable labour market prospects

reasonable labour market prospects moderate labour market prospects

moderate labour market prospects reasonable labour market prospects poor labour market prospects poor labour market prospects poor labour market prospects 
Appendix 6: The proportion of employees younger than thirty and the cyclical sensitivity $\left(\mathrm{FI}_{\mathrm{b}}\right)$ per occupational class

\begin{tabular}{|c|c|c|c|c|c|}
\hline CBS & Occupational class & $\begin{array}{l}\text { portion } \\
30 \text { year }\end{array}$ & qualification & $\mathrm{FI}_{\mathrm{b}}$ & qualification \\
\hline 01 & $\begin{array}{l}\text { Physical scientists and related } \\
\text { technicians }\end{array}$ & 0.37 & average & 1.72 & average \\
\hline $02 / 03$ & $\begin{array}{l}\text { Architects, engineers and related } \\
\text { technicians }\end{array}$ & 0.20 & relatively low & 2.12 & relatively high \\
\hline 04 & Aircraft and ship's officers & 0.26 & average & 1.25 & relatively low \\
\hline $\begin{array}{l}05 \\
06 / 07\end{array}$ & $\begin{array}{l}\text { Life scientists and technicians } \\
\text { Medical, dental, pharmaceutical and }\end{array}$ & 0.42 & relatively high & 1.48 & average \\
\hline 08 & $\begin{array}{l}\text { veterinary professions and assistants } \\
\text { Programmers, statisticians, and }\end{array}$ & 0.52 & relatively very high & 1.65 & average \\
\hline & assistants, etc. & 0.36 & average & 1.66 & average \\
\hline 09 & Economists & 0.18 & relatively low & 1.55 & average \\
\hline 11 & Accountants & 0.12 & relatively very low & 1.33 & relatively low \\
\hline 12 & Legal professionals and assistants & 0.21 & relatively low & 1.25 & relatively low \\
\hline 13 & Teachers & 0.23 & relatively low & 1.03 & relatively low \\
\hline 14 & Ministers of religion etc. & 0.09 & relatively very low & 1.53 & average \\
\hline 15 & Authors, journalists etc. & 0.24 & relatively low & 1.70 & average \\
\hline 16 & Creative artists and industrial and & & & & \\
\hline & interior designers & 0.25 & relatively low & 1.58 & average \\
\hline 17 & Performing artists & 0.30 & average & 1.51 & average \\
\hline 18 & Sports professionals etc. & 0.37 & average & 1.51 & average \\
\hline 19 & Miscellaneous professions & 0.25 & relatively low & 1.41 & relatively low \\
\hline 20 & Senior Government appointees & 0.00 & relatively very low & 1.07 & relatively low \\
\hline 21 & Company directors and senior executives & 0.05 & relatively very low & 2.06 & relatively high \\
\hline 30 & Departmental managers, administration & 0.14 & relatively very low & 1.48 & average \\
\hline 31 & Senior civil servants & 0.02 & relatively very low & 1.04 & relatively low \\
\hline 32 & Secretaries, typists, etc. & 0.52 & relatively very high & 1.58 & average \\
\hline 33 & Bookkeepers, cashiers, etc. & 0.46 & relatively high & 1.53 & average \\
\hline 34 & Computer operators etc. & 0.48 & relatively high & 1.62 & average \\
\hline 35 & Transport supervisors & 0.12 & relatively very low & 1.37 & relatively low \\
\hline 36 & Conductors, transport services & 0.33 & average & 1.12 & relatively low \\
\hline 37 & Postal workers and mail clerks & 0.38 & average & 1.20 & relatively low \\
\hline 38 & Radio, telephone and telegraph operators & 0.40 & average & 1.47 & average \\
\hline 39 & Miscellaneous administrative personnel & 0.43 & relatively high & 1.52 & average \\
\hline 40 & Managers, wholesale & 0.06 & relatively very low & 1.43 & relatively low \\
\hline 41 & Managers, retail & 0.14 & relatively very low & 1.43 & relatively low \\
\hline 42 & Working proprietors, wholesale & 0.13 & relatively very low & 1.43 & relatively low \\
\hline 43 & Working proprietors, retail & 0.12 & relatively very low & 1.43 & relatively low \\
\hline 45 & Departmental managers, purchasing and & & & & \\
\hline & sales & 0.25 & relatively low & 1.68 & average \\
\hline 46 & Sales representatives & 0.19 & relatively low & 1.71 & average \\
\hline 47 & Insurance agents, real estate & & & & \\
\hline & agents etc. & 0.21 & relatively low & 1.46 & average \\
\hline 48 & Shop assistants etc. & 0.53 & relatively very high & 1.46 & average \\
\hline 50 & $\begin{array}{l}\text { Managers, hotel and catering } \\
\text { industry }\end{array}$ & 0.00 & relatively very low & 1.46 & average \\
\hline 51 & $\begin{array}{l}\text { Working proprietors, hotel and } \\
\text { catering industry }\end{array}$ & 0.19 & relatively low & 1.30 & relatively low \\
\hline 52 & $\begin{array}{l}\text { Supervisors, catering, cleaning and } \\
\text { maintenance }\end{array}$ & 0.15 & relatively very low & 1.55 & average \\
\hline 53 & Cooks, waiters, bartenders etc. & 0.20 & relatively low & 1.45 & relatively low \\
\hline 54 & $\begin{array}{l}\text { Miscellaneous domestic, geriatric care, } \\
\text { and hotel workers }\end{array}$ & 0.50 & relatively high & 1.52 & average \\
\hline $\begin{array}{l}55 \\
56\end{array}$ & $\begin{array}{l}\text { Caretakers, cleaners etc. } \\
\text { Launderers, dry-cleaners and }\end{array}$ & 0.370 & average & 1.38 & relatively low \\
\hline & pressers & 0.22 & relatively low & 1.53 & average \\
\hline 57 & Hairdressers, barbers, beauticians etc & 0.44 & relatively high & 1.32 & relatively low \\
\hline 58 & Fire, police, and security officers & 0.53 & relatively very high & 1.17 & relatively low \\
\hline
\end{tabular}


Miscellaneous service workers

Farm managers and supervisors

Farmers

Agricultural workers

Forestry workers

Fishermen, hunters etc.

Production supervisors and general foremen

72 Furnace, casting, and galvanising workers etc.

73 Timber, pulp and paper workers

74 Chemical process workers etc.

75 Spinners, weavers, knitters,

dyers, etc.

77 Food and beverage processors,

abattoir workers

0.36

0.48

0.12

0.40

0.24

0.38

0.10

0.38

0.37

0.37

0.34

0.50

0.49

0.41

79

80

82

83

Tailors, dressmakers etc.

Shoemakers and leather goods

workers

0.40

Cabinetmakers, woodworkers,

stonemasons, etc.

average

0.35 average

0.40

0.44

miscellaneous metalworkers

84

85

87

89

90

91

92

93

94

95

96

97

98

99

69

Lathe operators, mechanics, etc.

0.38

\section{average}

relatively high

relatively very low

average

relatively low

average

relatively very low

average

average

average

average

relatively high

relatively high

relatively high

0.41

Plumbers, welders, sheet metal workers, etc.

0.40

0.45

Process workers, rubber and plastic products

0.45

products

Printers and related functions

0.41

0.44

0.41

Painters

Miscellaneous craftsmen and production workers

0.36

Building trades and construction

workers

Machine operators

0.39

0.36

Freight handlers, packers \& construction machine operators

0.13

0.41

Drivers, sailors, engine drivers

0.28

Miscellaneous labourers

0.44 average

relatively high

average

relatively high

average

relatively high

relatively high

relatively high

relatively high

average

average

average

relatively very low

relatively high

average

relatively high
1.63 average

1.20 relatively low

0.97 relatively very low

1.15 relatively low

1.45 relatively low

1.01 relatively low

2.46 relatively high

2.58 relatively very high

1.98 average

2.35 relatively high

3.91 relatively very high

1.16 relatively low

1.09 relatively low

3.12 relatively very high

3.33 relatively very high

2.25 relatively high

2.62 relatively very high

1.95 average

2.70 relatively very high

2.69 relatively very high

2.30 relatively high

2.49 relatively high

2.05 average

2.03 average

2.96 relatively very high

2.32 relatively high

3.26 relatively very high

2.04 average

1.85 average

1.35 relatively very low

2.66 relatively very high

1.01 relatively low 
Appendix 7: The relative prestige and the weighted function level per occupational class

\begin{tabular}{|c|c|c|c|c|}
\hline CBS & Occupational class & $\begin{array}{l}\text { relative } \\
\text { prestige }\end{array}$ & qualification & $\begin{array}{l}\text { weighted } \\
\text { function level }\end{array}$ \\
\hline 01 & $\begin{array}{l}\text { Physical scientists and related } \\
\text { technicians }\end{array}$ & 0.68 & relatively high & 4.9 \\
\hline \multirow[t]{2}{*}{$02 / 03$} & Architects, engineers and related & & & \\
\hline & technicians & 0.37 & average & 5.5 \\
\hline 04 & Aircraft and ship's officers & 1.56 & relatively very high & 4.6 \\
\hline 05 & Life scientists and technicians & 0.99 & relatively high & 5.4 \\
\hline 06/07 & $\begin{array}{l}\text { Medical, dental, pharmaceutical and } \\
\text { veterinary professions and assistants }\end{array}$ & 0.97 & relatively high & 5.0 \\
\hline \multirow[t]{2}{*}{08} & Programmers, statisticians, and & & & \\
\hline & assistants, etc. & 1.18 & relatively high & 6.0 \\
\hline 09 & Economists & 1.41 & relatively very high & 6.0 \\
\hline 11 & Accountants & 1.15 & relatively high & 6.2 \\
\hline 12 & Legal professionals and assistants & 2.13 & relatively very high & 7.0 \\
\hline 13 & Teachers & 1.12 & relatively high & 6.4 \\
\hline 14 & Ministers of religion etc. & 1.15 & relatively high & 5.7 \\
\hline 15 & Authors, journalists etc. & 1.00 & relatively high & 5.6 \\
\hline \multirow[t]{2}{*}{16} & Creative artists and industrial and & & & \\
\hline & interior designers & 0.01 & average & 4.9 \\
\hline 17 & Performing artists & 0.22 & average & 5.4 \\
\hline 18 & Sports professionals etc. & 0.32 & average & 5.0 \\
\hline 19 & Miscellaneous professions & 1.05 & relatively high & 5.8 \\
\hline 20 & Senior Government appointees & 2.18 & relatively very high & 6.4 \\
\hline 21 & Company directors and senior executives & 2.08 & relatively very high & 6.0 \\
\hline 30 & Departmental managers, administration & 1.00 & relatively high & 5.0 \\
\hline 31 & Senior civil servants & 1.25 & relatively high & 6.1 \\
\hline 32 & Secretaries, typists, etc. & 0.22 & average & 3.6 \\
\hline 33 & Bookkeepers, cashiers, etc. & 0.53 & relatively high & 3.5 \\
\hline 34 & Computer operators etc. & 0.89 & relatively high & 4.4 \\
\hline 35 & Transport supervisors & 0.22 & average & 3.5 \\
\hline 36 & Conductors, transport services & -0.30 & average & 2.0 \\
\hline 37 & Postal workers and mail clerks & -0.92 & relatively low & 1.7 \\
\hline 38 & Radio, telephone and telegraph operators & -0.71 & relatively low & 3.1 \\
\hline 39 & Miscellaneous administrative personnel & -0.40 & average & 2.8 \\
\hline 40 & Managers, wholesale & 1.72 & relatively very high & 6.0 \\
\hline 41 & Managers, retail & 0.37 & average & 6.0 \\
\hline 42 & Working proprietors, wholesale & 1.00 & relatively high & 5.0 \\
\hline 43 & Working proprietors, retail & 0.22 & average & 5.0 \\
\hline \multirow[t]{2}{*}{45} & Departmental managers, purchasing and & & & \\
\hline & sales & 0.37 & average & 5.2 \\
\hline 46 & Sales representatives & 0.32 & average & 4.2 \\
\hline 47 & Insurance agents, real estate agents etc. & 0.58 & relatively high & 4.1 \\
\hline 48 & Shop assistants etc. & -1.39 & relatively very low & 2.1 \\
\hline \multirow[t]{2}{*}{50} & Managers, hotel and catering & & & \\
\hline & industry & 0.89 & relatively high & 4.1 \\
\hline \multirow[t]{2}{*}{51} & Working proprietors, hotel and & & & \\
\hline & catering industry & 0.22 & average & 4.0 \\
\hline \multirow[t]{2}{*}{52} & Supervisors, catering, cleaning and & & & \\
\hline & maintenance & -0.40 & average & 5.0 \\
\hline \multirow{2}{*}{$\begin{array}{l}53 \\
54\end{array}$} & Cooks, waiters, bartenders etc. & -0.61 & relatively low & 2.2 \\
\hline & $\begin{array}{l}\text { Miscellaneous domestic, geriatric care, } \\
\text { and hotel workers }\end{array}$ & -1.02 & relatively low & 2.8 \\
\hline \multirow[t]{2}{*}{$\begin{array}{l}55 \\
56\end{array}$} & $\begin{array}{l}\text { Caretakers, cleaners etc. } \\
\text { Launderers, dry-cleaners and }\end{array}$ & -1.59 & relatively very low & 1.3 \\
\hline & pressers & -1.59 & relatively very low & 1.1 \\
\hline 57 & Hairdressers, barbers, beauticians etc & -0.19 & average & 3.8 \\
\hline
\end{tabular}




\begin{tabular}{|c|c|c|c|c|}
\hline CBS & Occupational class & $\begin{array}{l}\text { relative } \\
\text { prestige }\end{array}$ & qualification & $\begin{array}{l}\text { weighted } \\
\text { function level }\end{array}$ \\
\hline 58 & Fire, police, and security officers & 0.51 & relatively high & 3.1 \\
\hline 59 & Miscellaneous service workers & -0.04 & average & 3.0 \\
\hline 60 & Farm managers and supervisors & 0.22 & average & 5.0 \\
\hline 61 & Farmers & -0.50 & average & 5.0 \\
\hline 62 & Agricultural workers & -0.97 & relatively low & 2.1 \\
\hline 63 & Forestry workers & -0.61 & relatively low & 2.5 \\
\hline 64 & Fishermen, hunters etc. & -0.81 & relatively low & 2.2 \\
\hline 69 & Military professionals & 1.10 & relatively low & 6.0 \\
\hline 70 & $\begin{array}{l}\text { Production supervisors and general } \\
\text { foremen }\end{array}$ & 0.17 & average & 4.8 \\
\hline 72 & $\begin{array}{l}\text { Furnace, casting, and galvanising } \\
\text { workers etc. }\end{array}$ & -112 & relatively low & \\
\hline 73 & Timber, pulp and paper workers & -1.38 & relatively very low & $\begin{array}{l}1.7 \\
1.8\end{array}$ \\
\hline 74 & Chemical process workers etc. & -0.30 & average & 2.4 \\
\hline 75 & $\begin{array}{l}\text { Spinners, weavers, knitters, } \\
\text { dyers, etc. }\end{array}$ & -0.87 & relatively low & 2.1 \\
\hline 77 & $\begin{array}{l}\text { Food and beverage processors, } \\
\text { abattoir workers }\end{array}$ & -1.54 & relatively very low & 2.4 \\
\hline 78 & Tobacco and tobacco product workers & -0.87 & relatively low & 1.3 \\
\hline 79 & Tailors, dressmakers etc. & -0.71 & relatively low & 2.2 \\
\hline 80 & $\begin{array}{l}\text { Shoemakers and leather goods } \\
\text { workers }\end{array}$ & -1.32 & relatively very low & 1.9 \\
\hline 82 & $\begin{array}{l}\text { Cabinetmakers, woodworkers, } \\
\text { stonemasons, etc. }\end{array}$ & -0.61 & relatively low & 2.5 \\
\hline 83 & $\begin{array}{l}\text { Blacksmiths, toolmakers, and } \\
\text { miscellaneous metalworkers }\end{array}$ & -0.45 & average & 2.5 \\
\hline 84 & Lathe operators, mechanics, etc. & -0.81 & relatively low & 3.9 \\
\hline $\begin{array}{l}85 \\
87\end{array}$ & $\begin{array}{l}\text { Electrical and electronics workers } \\
\text { Plumbers, welders, sheet metal workers, }\end{array}$ & 0.32 & average & 3.8 \\
\hline & etc. & -1.12 & relatively low & 3.3 \\
\hline $\begin{array}{l}89 \\
90\end{array}$ & $\begin{array}{l}\text { Glass and ceramics workers etc. } \\
\text { Process workers, rubber and plastic }\end{array}$ & -1.38 & relatively very low & 1.4 \\
\hline & products & -1.38 & relatively very low & 1.3 \\
\hline 91 & $\begin{array}{l}\text { Process workers, paper and card } \\
\text { products }\end{array}$ & -1.38 & relatively very low & 1.0 \\
\hline 92 & Printers and related functions & -0.35 & average & 2.7 \\
\hline 93 & Painters & -0.97 & relatively low & 2.8 \\
\hline 94 & $\begin{array}{l}\text { Miscellaneous craftsmen and production } \\
\text { workers }\end{array}$ & -0.61 & relatively low & 1.7 \\
\hline 95 & $\begin{array}{l}\text { Building trades and construction } \\
\text { workers }\end{array}$ & -0.92 & relatively low & 3.3 \\
\hline 96 & Machine operators & -0.30 & average & 2.4 \\
\hline 97 & $\begin{array}{l}\text { Freight handlers, packers \& construction } \\
\text { machine operators }\end{array}$ & -0.30 & average & 1.3 \\
\hline $\begin{array}{l}98 \\
99\end{array}$ & $\begin{array}{l}\text { Drivers, sailors, engine drivers } \\
\text { Miscellaneous labourers }\end{array}$ & $\begin{array}{l}-0.76 \\
-1.64\end{array}$ & $\begin{array}{l}\text { relatively low } \\
\text { relatively very low }\end{array}$ & $\begin{array}{l}2.0 \\
1.0\end{array}$ \\
\hline & Average & 0.01 & average & 3.7 \\
\hline
\end{tabular}


Appendix 8: The unemployment figure and alternative occupations at a matching function level (GH)

Type of education

unemployment qualification

$\mathrm{GH}$

qualification figure

\begin{tabular}{|c|c|c|c|c|}
\hline Primary Education & 28 & relatively very high & & \\
\hline Lower General Secondary Education & 14 & relatively high & 0.84 & relatively high \\
\hline Lower Vocational Education, Agriculture & 5 & relatively low & 0.73 & average \\
\hline $\begin{array}{l}\text { Lower Vocational Education, Technical } \\
\text { Lower Vocational Education, Transport }\end{array}$ & 11 & average & 0.82 & relatively high \\
\hline $\begin{array}{l}\text { \& Harbour } \\
\text { Lower Vocational Education, Commerce }\end{array}$ & 4 & relatively low & 0.29 & relatively very low \\
\hline $\begin{array}{l}\text { \& Administration } \\
\text { Lower Vocational Education, Community }\end{array}$ & 15 & relatively high & 0.82 & relatively high \\
\hline Care, Hotel \& Catering & 13 & relatively high & 0.54 & relatively very low \\
\hline $\begin{array}{l}\text { Higher General Secondary Education } \\
\text { Intermediate Vocational Education, }\end{array}$ & 17 & relatively very high & 0.83 & relatively high \\
\hline $\begin{array}{l}\text { Agriculture } \\
\text { Intermediate Vocational Education, }\end{array}$ & 3 & relatively very low & 0.74 & average \\
\hline $\begin{array}{l}\text { Engineering and Laboratory } \\
\text { Intermediate Vocational Education, }\end{array}$ & 2 & relatively very low & 0.86 & relatively high \\
\hline Transport, Harbour \& Telecommunications & 2 & relatively very low & 0.74 & average \\
\hline $\begin{array}{l}\text { Intermediate Vocational Education, Nursing } \\
\text { Intermediate Vocational Education, Medical }\end{array}$ & 4 & relatively low & 0.67 & average \\
\hline $\begin{array}{l}\text { Laboratory } \\
\text { Intermediate Vocational Education, }\end{array}$ & 3 & relatively very low & 0.75 & average \\
\hline $\begin{array}{l}\text { Para-medical services } \\
\text { Intermediate Vocational Education, }\end{array}$ & 4 & relatively low & 0.51 & relatively very low \\
\hline $\begin{array}{l}\text { Commerce \& Administration } \\
\text { Intermediate Vocational Education, }\end{array}$ & 2 & relatively very low & 0.86 & relatively high \\
\hline $\begin{array}{l}\text { Administrative, Legal \& Fiscal } \\
\text { Intermediate Vocational Education, }\end{array}$ & 1 & relatively very low & 0.77 & average \\
\hline $\begin{array}{l}\text { Social \& Cultural } \\
\text { Intermediate Vocational Education, }\end{array}$ & 13 & relatively high & 0.79 & average \\
\hline $\begin{array}{l}\text { Community Care } \\
\text { Intermediate Vocational Education, }\end{array}$ & 7 & relatively low & 0.63 & relatively low \\
\hline $\begin{array}{l}\text { Hotel, Catering \& Hairdressing } \\
\text { Intermediate Vocational Education, }\end{array}$ & 5 & relatively low & 0.78 & average \\
\hline $\begin{array}{l}\text { Police, Fire \& Defense Forces } \\
\text { Higher Vocational Education, Teacher }\end{array}$ & 0 & relatively very low & 0.38 & relatively very low \\
\hline $\begin{array}{l}\text { Education* } \\
\text { Higher Vocational Education, Interpreter }\end{array}$ & 6 & relatively low & 0.77 & average \\
\hline \& Translator & 10 & average & 0.80 & average \\
\hline Higher Vocational Education, Theology & 3 & relatively very low & 0.51 & relatively very low \\
\hline $\begin{array}{l}\text { Higher Vocational Education, Agriculture } \\
\text { Higher Vocational Education, Non-medical }\end{array}$ & 6 & relatively low & 0.90 & relatively high \\
\hline Laboratory* * & 3 & relatively very low & 0.80 & average \\
\hline $\begin{array}{l}\text { Higher Vocational Education, Engineering } \\
\text { Higher Vocational Education, Air, }\end{array}$ & 3 & relatively very low & 0.95 & relatively very high \\
\hline $\begin{array}{l}\text { Sea and Land Transport } \\
\text { Higher Vocational Education, Nursing }\end{array}$ & 3 & relatively very low & 0.77 & average \\
\hline $\begin{array}{l}\text { \& Physiotherapy etc. } \\
\text { Higher Vocational Education, Medical }\end{array}$ & 6 & relatively low & 0.73 & average \\
\hline $\begin{array}{l}\text { Laboratory** } \\
\text { Higher Vocational Education, Commerce }\end{array}$ & 3 & relatively very low & 0.70 & average \\
\hline $\begin{array}{l}\text { \& Administration } \\
\text { Higher Vocational Education, Business }\end{array}$ & 1 & relatively very low & 0.67 & average \\
\hline Administration Technology & 5 & relatively low & 0.91 & relatively very high \\
\hline $\begin{array}{l}\text { Higher Vocational Education, Administrative, } \\
\text { Legal \& Fiscal }\end{array}$ & 4 & relatively low & 0.78 & average \\
\hline
\end{tabular}


Higher Vocational Education, Social \& Cultural

\begin{tabular}{|c|c|c|c|}
\hline 13 & relatively high & 0.79 & average \\
\hline $\begin{array}{r}6 \\
25\end{array}$ & $\begin{array}{l}\text { relatively low } \\
\text { relatively very high }\end{array}$ & $\begin{array}{l}0.79 \\
0.85\end{array}$ & $\begin{array}{l}\text { average } \\
\text { relatively high }\end{array}$ \\
\hline $\begin{array}{r}0 \\
6 \\
17 \\
3 \\
13\end{array}$ & $\begin{array}{l}\text { relatively very low } \\
\text { relatively low } \\
\text { relatively very high } \\
\text { relatively very low } \\
\text { relatively high }\end{array}$ & $\begin{array}{l}0.59 \\
0.47 \\
0.65 \\
0.55 \\
0.89\end{array}$ & $\begin{array}{l}\text { relatively low } \\
\text { relatively very low } \\
\text { relatively low } \\
\text { relatively very low } \\
\text { relatively high }\end{array}$ \\
\hline $\begin{array}{l}8 \\
3\end{array}$ & $\begin{array}{l}\text { average } \\
\text { relatively very low }\end{array}$ & $\begin{array}{l}0.91 \\
0.95\end{array}$ & $\begin{array}{l}\text { relatively very high } \\
\text { relatively very high }\end{array}$ \\
\hline $\begin{array}{l}4 \\
3\end{array}$ & $\begin{array}{l}\text { relatively low } \\
\text { relatively very low }\end{array}$ & $\begin{array}{l}0.55 \\
0.71\end{array}$ & $\begin{array}{l}\text { relatively very low } \\
\text { average }\end{array}$ \\
\hline 4 & relatively low & 0.90 & relatively high \\
\hline 3 & relatively very low & 0.86 & relatively high \\
\hline $\begin{array}{r}8 \\
14 \\
32\end{array}$ & $\begin{array}{l}\text { average } \\
\text { relatively high } \\
\text { relatively. very high }\end{array}$ & $\begin{array}{l}0.83 \\
0.80 \\
0.81\end{array}$ & $\begin{array}{l}\text { relatively high } \\
\text { average } \\
\text { relatively high }\end{array}$ \\
\hline
\end{tabular}

Higher Vocational Education, Hotel \&

Catering Industry

Higher Vocational Education, Fine Arts

Higher Vocational Education, Police, Fire

\& Defense Forces

Academic Education, Teacher training*

Academic Education, Arts

Academic Education, Theology

Academic Education, Agriculture

Academic Education, Mathematics

\& Natural Sciences

Academic Education, Engineering

Academic Education, Vetinary \& Medical

Sciences \& Dentistry

Academic Education, Pharmacy

Academic Education, Economics \&

Business Administration

Academic Education, Econometrics \&

Business Administration Technology

Academic Education, Law \& Public

Administration

Academic Education, Social Sciences

Academic Education, Fine Arts relatively. very high 0.81

* Unemployment determined for Academic Education and Higher Vocational Education together

* Unemployment determined for non-medical and medical laboratory together 
Appendix 9: Under-utilization and weighted function level per educational type in 1985

\begin{tabular}{|c|c|c|c|}
\hline unde & $\begin{array}{l}\text { \% } \\
\%\end{array}$ & qualification & $\begin{array}{l}\text { weighted } \\
\text { function level }\end{array}$ \\
\hline Primary Education & - & & 2.4 \\
\hline \multicolumn{4}{|l|}{ Lower General Secondary } \\
\hline Education & 38 & average & 3.0 \\
\hline Lower Vocational Education, Agriculture & 35 & average & 3.7 \\
\hline Lower Vocational Education, Technical & 41 & average & 3.0 \\
\hline $\begin{array}{l}\text { Lower Vocational Education, Transport } \\
\text { \& Harbour }\end{array}$ & 85 & relatively very high & 2.2 \\
\hline $\begin{array}{l}\text { Lower Vocational Education, Commerce } \\
\text { \& Administration }\end{array}$ & 36 & 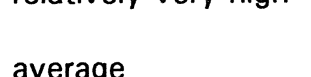 & 3.0 \\
\hline \multicolumn{4}{|l|}{ Lower Vocational Education, Community } \\
\hline Care, Hotel \& Catering & 67 & relatively very high & 2.4 \\
\hline Lower Vocational Education, Security & 89 & relatively very high & 2.4 \\
\hline Higher General Secondary Education & 49 & relatively high & 3.8 \\
\hline $\begin{array}{l}\text { Intermediate Vocational Education, Agriculture } \\
\text { Intermediate Vocational Education, }\end{array}$ & 38 & average & 3.9 \\
\hline Engineering and Laboratory & 37 & average & 3.7 \\
\hline \multicolumn{4}{|l|}{ Intermediate Vocational Education, Transport, } \\
\hline $\begin{array}{l}\text { Harbour \& Telecommunications } \\
\text { Intermediate Vocational Education, Nursing }\end{array}$ & $\begin{array}{l}63 \\
15\end{array}$ & $\begin{array}{l}\text { relatively very high } \\
\text { relatively low }\end{array}$ & $\begin{array}{l}3.3 \\
4.6\end{array}$ \\
\hline \multicolumn{4}{|l|}{ Intermediate Vocational Education, Medical } \\
\hline Laboratory & 12 & relatively low & 4.2 \\
\hline $\begin{array}{l}\text { Intermediate Vocational Education, Para-medical } \\
\text { services }\end{array}$ & & relativelv lone & 27 \\
\hline \multicolumn{4}{|l|}{ Intermediate Vocational Education, Commerce \& } \\
\hline Administration & 46 & relatively high & 3.8 \\
\hline \multicolumn{4}{|l|}{ Intermediate Vocational Education, Administrative, } \\
\hline Legal \& Fiscal & 44 & average & 3.8 \\
\hline Intermediate Vocational Education, Social \& & & & \\
\hline Cultural & 40 & average & 4.2 \\
\hline \multicolumn{4}{|l|}{ Intermediate Vocational Education, Community } \\
\hline Care & 61 & relatively high & 3.3 \\
\hline Intermediate Vocational Education, Hotel, & & & \\
\hline Catering \& Hairdressing & 26 & average & 3.6 \\
\hline \multicolumn{4}{|l|}{ Intermediate Vocational Education, Police, Fire } \\
\hline \& Defense Forces & 79 & relatively very high & 3.1 \\
\hline Higher Vocational Education, Teacher & & & \\
\hline Education & 12 & relatively low & 5.8 \\
\hline \multicolumn{4}{|l|}{ Higher Vocational Education, Interpreter \& } \\
\hline Translator & 36 & average & 5.2 \\
\hline Higher Vocational Education, Theology & 13 & relatively low & 5.7 \\
\hline Higher Vocational Education, Agriculture & 21 & relatively low & 5.2 \\
\hline \multicolumn{4}{|l|}{ Higher Vocational Education, Non-medical } \\
\hline Laboratory & 53 & relatively high & 4.8 \\
\hline Higher Vocational Education, Engineering & 15 & relatively low & 5.4 \\
\hline Higher Vocational Education, Air, Sea and & & & \\
\hline Land Transport & 46 & relatively high & 4.6 \\
\hline \multicolumn{4}{|l|}{ Higher Vocational Education, Nursing \& } \\
\hline Physiotherapy etc & 6 & relatively low & 5.2 \\
\hline $\begin{array}{l}\text { Higher Vocational Education, Medical Laboratory } \\
\text { Higher Vocational Education, Commerce \& }\end{array}$ & 17 & relatively low & 4.8 \\
\hline Administration & 56 & relatively high & 4.5 \\
\hline \multicolumn{4}{|l|}{ Higher Vocational Education, Business } \\
\hline Administration Technology & 19 & relatively low & 5.3 \\
\hline $\begin{array}{l}\text { Higher Vocational Education, Administrative, } \\
\text { Legal \& Fiscal }\end{array}$ & 40 & average & 4.9 \\
\hline
\end{tabular}


under-utilization

$\%$

qualification

weighted

function level

Higher Vocational Education, Social \&

Cultural

20

relatively low

5.1

Higher Vocational Education, Hotel \& Catering Industry

Higher Vocational Education, Fine Arts

Higher Vocational Education, Police, Fire

\& Defense Forces

Academic Education, Teacher training

Academic Education, Arts

Academic Education, Theology

Academic Education, Agriculture

Academic Education, Mathematics \&

Natural Sciences

Academic Education, Engineering

Academic Education, Veterinary \& Medical

Sciences\& Dentistry

Academic Education, Pharmacy

Academic Education, Economics \& Business

Administration

Academic Education, Econometrics \& Business

Administration Technology

Academic Education, Law \& Public Sciences

Academic Education, Social Sciences

Academic Education, Fine Arts
40

11

\section{average}

relatively low

4.6

62

7

9

13

23

9

14

4

4

15

39

15

25

42 relatively very high

relatively low

relatively low

relatively low

average

5.3

3.8

6.4

6.2

5.8

5.8

relatively low

6.5

relatively low

6.2

relatively very low

6.8

relatively very low

6.8

relatively low

5.8

average

5.7

relatively low

6.2

average

6.0

average

5.6 
Appendix 10: The most important educational backgrounds for all women's occupations, differentiated by sex in 1985 (between accolades: as percentages)

\begin{tabular}{|c|c|c|c|}
\hline \multicolumn{2}{|c|}{ Women's occupations } & \multirow{2}{*}{$\begin{array}{l}\text { Men } \\
\text { Academic Education, Veterinary \& } \\
\text { Medical Sciences \& Dentistry (33) }\end{array}$} & \multirow{2}{*}{$\begin{array}{l}\text { Women } \\
\text { Intermediate Vocational Education, } \\
\text { Nursing (28) }\end{array}$} \\
\hline 06/07 & $\begin{array}{l}\text { Medical, dental, } \\
\text { pharmaceutical }\end{array}$ & & \\
\hline & & $\begin{array}{l}\text { Intermediate Vocational Education, } \\
\text { Nursing (18) } \\
\text { Higher Vocational Education, } \\
\text { Nursing \& Physiotherapy etc (18) }\end{array}$ & $\begin{array}{l}\text { Higher Vocational Education, } \\
\text { Nursing \& Physiotherapy etc (14) } \\
\text { Intermediate Vocational Education, } \\
\text { Community Care (13) } \\
\text { Intermediate Vocational Education, } \\
\text { Para-medical services (13) }\end{array}$ \\
\hline 32 & $\begin{array}{l}\text { Secretaries, } \\
\text { Typists etc }\end{array}$ & $\begin{array}{l}\text { Intermediate Vocational Education, } \\
\text { Commerce \& Administration (23) }\end{array}$ & $\begin{array}{l}\text { Intermediate Vocational Education, } \\
\text { Commerce \& Administration (31) }\end{array}$ \\
\hline & & $\begin{array}{l}\text { Lower General Secondary } \\
\text { Education (19) } \\
\text { Higher General Secondary } \\
\text { Education(12) }\end{array}$ & $\begin{array}{l}\text { Higher Vocational Education, } \\
\text { Commerce \& Administration (15) } \\
\text { Lower General Secondary } \\
\text { Education (15) } \\
\text { Higher General Secondary } \\
\text { Education (11) } \\
\text { Lower Vocational Education, } \\
\text { Commerce \& Administration (10) }\end{array}$ \\
\hline \multirow[t]{2}{*}{38} & $\begin{array}{l}\text { Radio, telephone } \\
\text { and telegraph } \\
\text { operators }\end{array}$ & $\begin{array}{l}\text { Higher Vocational Education, Air, } \\
\text { Sea and Land Transport (16) }\end{array}$ & $\begin{array}{l}\text { Lower General Secondary } \\
\text { Education }(28)\end{array}$ \\
\hline & & $\begin{array}{l}\text { Intermediate Vocational Education, } \\
\text { Police, Fire \& Defense Forces (14) } \\
\text { Lower General Secondary } \\
\text { Education (14) } \\
\text { Higher General Secondary } \\
\text { Education (13) }\end{array}$ & $\begin{array}{l}\text { Intermediate Vocational Education, } \\
\text { Commerce \& Administration (15) } \\
\text { Higher General Secondary } \\
\text { Education (12) }\end{array}$ \\
\hline 48 & $\begin{array}{l}\text { Shop assistants } \\
\text { etc }\end{array}$ & $\begin{array}{l}\text { Intermediate Vocational Education, } \\
\text { Commerce \& Administration ( } 25)\end{array}$ & $\begin{array}{l}\text { Lower Vocational Education, } \\
\text { Community Care, Hotel \& Catering } \\
\text { (22) }\end{array}$ \\
\hline & & $\begin{array}{l}\text { Primary Education (15) } \\
\text { Lower General Secondary } \\
\text { Education(15) } \\
\text { Lower Vocational Education, } \\
\text { Technical (12) }\end{array}$ & $\begin{array}{l}\text { Primary Education (17) } \\
\text { Lower General Secondary } \\
\text { Education (16) } \\
\text { Intermediate Vocational Education, } \\
\text { Commerce \& Administration (14) }\end{array}$ \\
\hline 53 & $\begin{array}{l}\text { Cooks, waiters, } \\
\text { bartenders etc. }\end{array}$ & $\begin{array}{l}\text { Lower Vocational Education } \\
\text { Community Care, Hotel \& Catering } \\
\text { (33) } \\
\text { Primary Education (21) } \\
\text { Lower Vocational Education, } \\
\text { Technical (10) } \\
\text { Lower General Secondary } \\
\text { Education (7) }\end{array}$ & $\begin{array}{l}\text { Lower Vocational Education, } \\
\text { Community Care, Hotel \& Catering } \\
\text { (28) } \\
\text { Primary Education (28) } \\
\text { Lower General Secondary } \\
\text { Education (11) } \\
\text { Intermediate Vocational Education, } \\
\text { Community Care (10) }\end{array}$ \\
\hline 54 & $\begin{array}{l}\text { Miscellaneous } \\
\text { domestic geriatric } \\
\text { care, and hotel } \\
\text { workers }\end{array}$ & Primary Education (24) & $\begin{array}{l}\text { Intermediate Vocational Education, } \\
\text { Community Care (25) }\end{array}$ \\
\hline
\end{tabular}




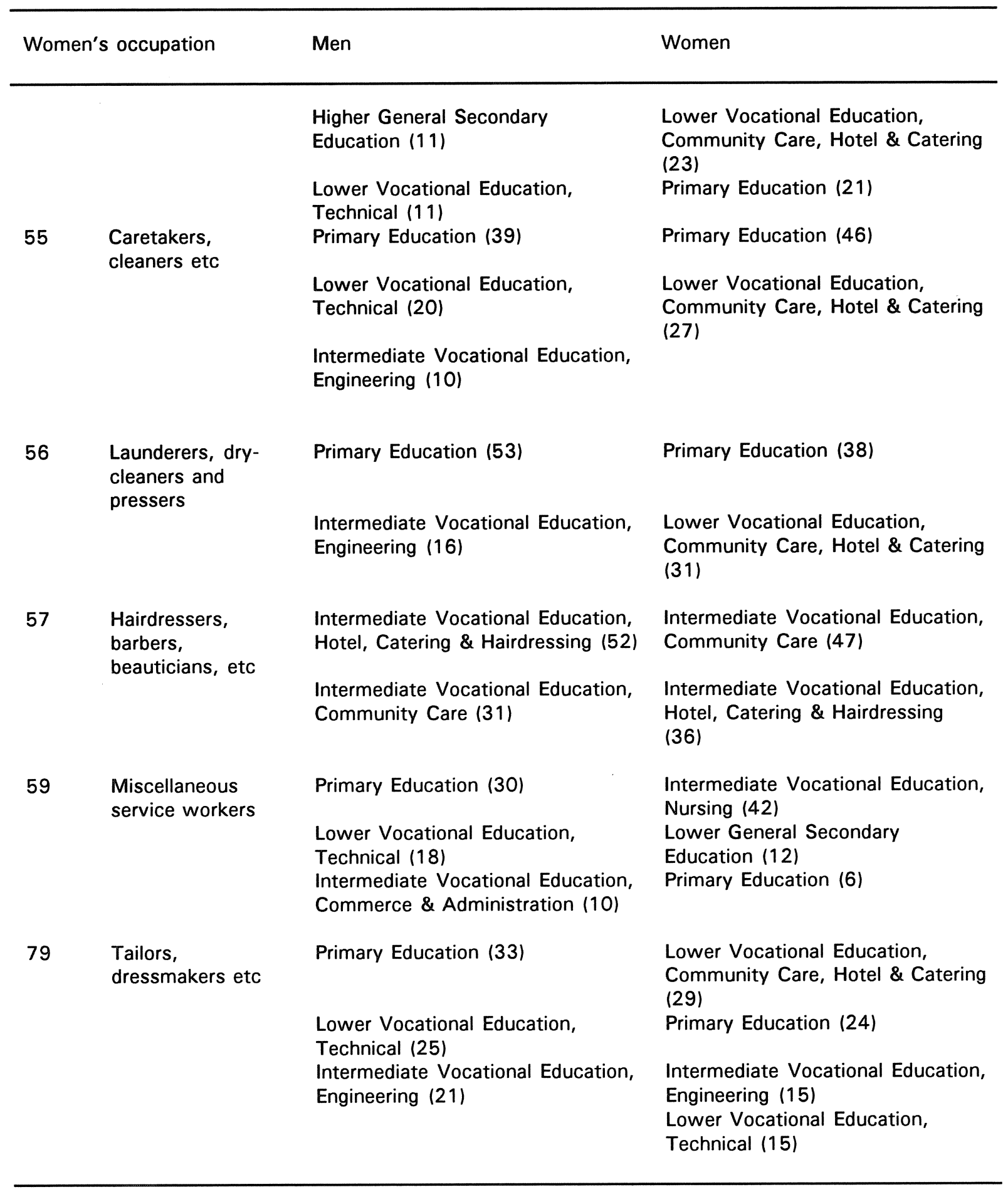


Appendix 11: The most important occupational classes in which the labour force with a female educational background is located, differentiated by sex in 1985 (between accolades: as percentages)

\begin{tabular}{|c|c|c|}
\hline Women's education & Men & Women \\
\hline \multirow{2}{*}{$\begin{array}{l}\text { Lower Vocational } \\
\text { Education, Commerce } \\
\text { \& Administration }\end{array}$} & Bookkeepers, cashiers etc (22) & $\begin{array}{l}\text { Miscellaneous administrative } \\
\text { personnel (22) }\end{array}$ \\
\hline & $\begin{array}{l}\text { Miscellaneous administrative } \\
\text { personnel (15) } \\
\text { Shop assistants, etc. (7) }\end{array}$ & $\begin{array}{l}\text { Secretaries, typists, etc. (17) } \\
\text { Bookkeepers, cashiers, etc. (17) } \\
\text { Shop assistants, etc. (16) }\end{array}$ \\
\hline \multirow{2}{*}{$\begin{array}{l}\text { Lower Vocational } \\
\text { Education, Community } \\
\text { Care, Hotel \& Catering }\end{array}$} & Cooks, waiters, bartenders, etc. (69) & $\begin{array}{l}\text { Miscellaneous domestic, geriatric } \\
\text { care, and hotel workers (19) }\end{array}$ \\
\hline & $\begin{array}{l}\text { Working proprietors, hotel and } \\
\text { catering (12) } \\
\text { Caretakers, cleaners, etc. (5) }\end{array}$ & $\begin{array}{l}\text { Shop assistants, etc. (17) } \\
\text { Caretakers, cleaners, etc. (13) } \\
\text { Cooks, waiters, bartenders, etc. (9) }\end{array}$ \\
\hline $\begin{array}{l}\text { Intermediate Vocational } \\
\text { Education, Nursing }\end{array}$ & $\begin{array}{l}\text { Medical, dental, pharmaceutical and } \\
\text { veterinary professions and } \\
\text { assistants, etc. (88) }\end{array}$ & $\begin{array}{l}\text { Medical, dental, pharmaceutical and } \\
\text { veterinary professions and } \\
\text { assistants, etc. (64) } \\
\text { Miscellaneous service workers (10) } \\
\text { Miscellaneous domestic, geriatric } \\
\text { care, and hotel workers (7) }\end{array}$ \\
\hline \multirow[t]{2}{*}{$\begin{array}{l}\text { Intermediate Vocational } \\
\text { Education, Medical } \\
\text { Laboratory }\end{array}$} & $\begin{array}{l}\text { Medical, dental, pharmaceutical and } \\
\text { veterinary professions and } \\
\text { assistants, etc. (30) }\end{array}$ & $\begin{array}{l}\text { Medical, dental, pharmaceutical and } \\
\text { veterinary professions and } \\
\text { assistants, etc. (68) }\end{array}$ \\
\hline & $\begin{array}{l}\text { Lathe operators, mechanics, etc. } \\
\text { (18) } \\
\text { Working proprietors, retail (9) } \\
\text { Programmers, statisticians, and } \\
\text { assistants, etc. (7) }\end{array}$ & $\begin{array}{l}\text { Programmers, statisticians and } \\
\text { assistants, etc. (11) }\end{array}$ \\
\hline $\begin{array}{l}\text { Intermediate Vocational } \\
\text { Education, Para-medical } \\
\text { services }\end{array}$ & $\begin{array}{l}\text { Medical, dental, pharmaceutical and } \\
\text { veterinary professions and } \\
\text { assistants, etc. (82) }\end{array}$ & $\begin{array}{l}\text { Medical, dental, pharmaceutical and } \\
\text { veterinary professions and } \\
\text { assistants, etc. (73) } \\
\text { Miscellaneous domestic, geriatric } \\
\text { care, and hotel workers (15) }\end{array}$ \\
\hline
\end{tabular}




\begin{tabular}{|c|c|c|}
\hline Women's education & Men & Women \\
\hline $\begin{array}{l}\text { Intermediate Vocational } \\
\text { Education, Community } \\
\text { Care }\end{array}$ & $\begin{array}{l}\text { Medical, dental, pharmaceutical and } \\
\text { veterinary professions and } \\
\text { assistants, etc. ( } 26) \\
\text { Hairdressers, barbers, beauticians, } \\
\text { etc (19) } \\
\text { Cooks, waiters, bartenders etc (8) } \\
\text { Miscellaneous domestic, geriatric } \\
\text { care, and hotel workers (7) }\end{array}$ & $\begin{array}{l}\text { Miscellaneous domestic, geriatric } \\
\text { care, and hotel workers (33) } \\
\text { Medical, dental, pharmaceutical and } \\
\text { veterinary professions and } \\
\text { assistants, etc. (19) } \\
\text { Hairdressers, barbers, beauticians, } \\
\text { etc. (8) } \\
\text { Shop assistants, etc. (8) }\end{array}$ \\
\hline $\begin{array}{l}\text { Higher Vocational } \\
\text { Education, Nursing \& } \\
\text { Physiotherapy etc }\end{array}$ & $\begin{array}{l}\text { Medical, dental, pharmaceutical and } \\
\text { veterinary professions and assistants } \\
\text { (87) }\end{array}$ & $\begin{array}{l}\text { Medical, dental, pharmaceutical and } \\
\text { veterinary professions and } \\
\text { assistants, etc. ( } 88 \text { ) }\end{array}$ \\
\hline \multirow{2}{*}{$\begin{array}{l}\text { Higher Vocational } \\
\text { Education, Medical } \\
\text { Laboratory }\end{array}$} & $\begin{array}{l}\text { Programmers, statisticians and } \\
\text { assistants, etc. (48) }\end{array}$ & $\begin{array}{l}\text { Programmers, statisticians, and } \\
\text { assistants, etc. (48) }\end{array}$ \\
\hline & $\begin{array}{l}\text { Medical, dental, pharmaceutical and } \\
\text { veterinary professions and assistants } \\
(22) \\
\text { Physical scientists and related } \\
\text { technicians (15) }\end{array}$ & $\begin{array}{l}\text { Medical, dental, pharmaceutical and } \\
\text { veterinary professions and } \\
\text { assistants, etc. (34) } \\
\text { Physical scientists and related } \\
\text { technicians (6) }\end{array}$ \\
\hline
\end{tabular}

